July 2003 • NREL/TP-550-33294

\title{
Energy Design Analysis and Evaluation of a Proposed Air Rescue and Fire Fighting Administration Building for Teterboro Airport
}

B. Griffith, S. Pless, B. Talbert, M. Deru, and $P$. Torcellini
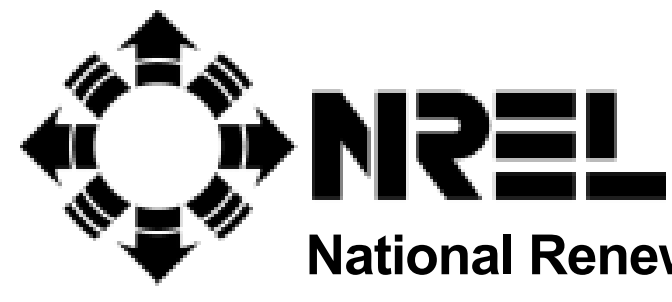

National Renewable Energy Laboratory

1617 Cole Boulevard

Golden, Colorado 80401-3393

NREL is a U.S. Department of Energy Laboratory

Operated by Midwest Research Institute • Battelle • Bechtel

Contract No. DE-AC36-99-G010337 
July 2003 • NREL/TP-550-33294

\section{Energy Design Analysis and Evaluation of a Proposed Air Rescue and Fire Fighting Administration Building for Teterboro Airport}

B. Griffith, S. Pless, B. Talbert, M. Deru, and $\mathrm{P}$. Torcellini

Prepared under Task No. BEC2.4005

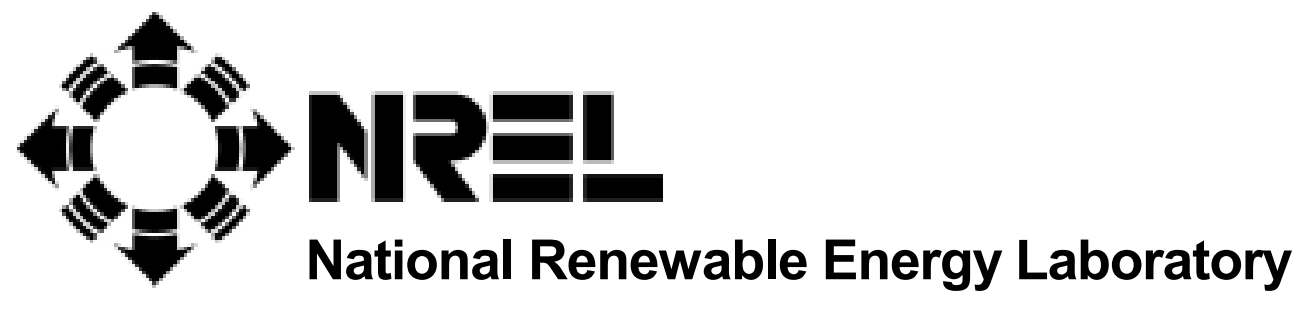

1617 Cole Boulevard

Golden, Colorado 80401-3393

NREL is a U.S. Department of Energy Laboratory

Operated by Midwest Research Institute $\bullet$ Battelle $\bullet$ Bechtel

Contract No. DE-AC36-99-G010337 


\section{NOTICE}

This report was prepared as an account of work sponsored by an agency of the United States government. Neither the United States government nor any agency thereof, nor any of their employees, makes any warranty, express or implied, or assumes any legal liability or responsibility for the accuracy, completeness, or usefulness of any information, apparatus, product, or process disclosed, or represents that its use would not infringe privately owned rights. Reference herein to any specific commercial product, process, or service by trade name, trademark, manufacturer, or otherwise does not necessarily constitute or imply its endorsement, recommendation, or favoring by the United States government or any agency thereof. The views and opinions of authors expressed herein do not necessarily state or reflect those of the United States government or any agency thereof.

Available electronically at http://www.osti.gov/bridge

Available for a processing fee to U.S. Department of Energy and its contractors, in paper, from:

U.S. Department of Energy

Office of Scientific and Technical Information

P.O. Box 62

Oak Ridge, TN 37831-0062

phone: 865.576 .8401

fax: 865.576.5728

email: reports@adonis.osti.gov

Available for sale to the public, in paper, from:

U.S. Department of Commerce

National Technical Information Service

5285 Port Royal Road

Springfield, VA 22161

phone: 800.553.6847

fax: 703.605.6900

email: orders@ntis.fedworld.gov

online ordering: http://www.ntis.gov/ordering.htm 


\section{Contents}

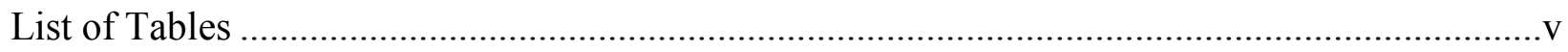

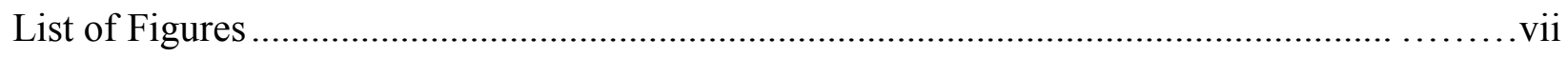

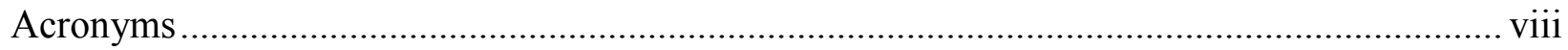

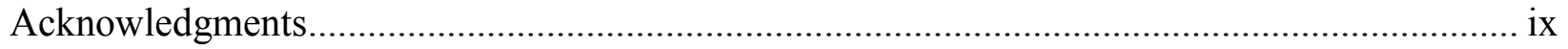

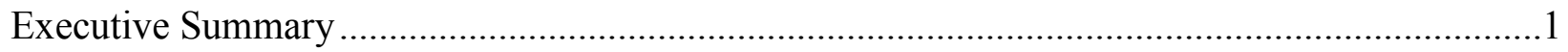

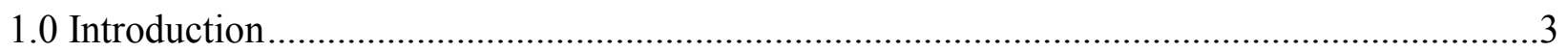

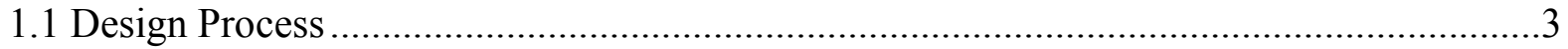

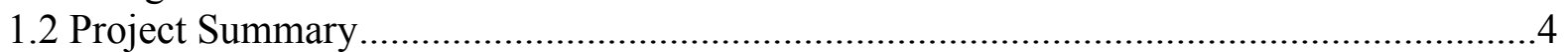

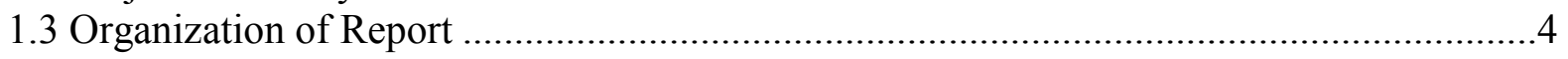

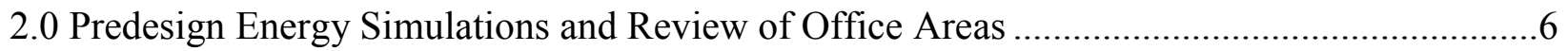

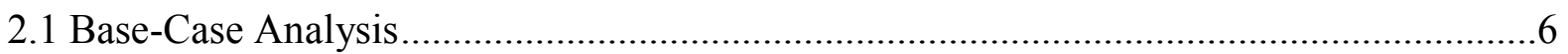

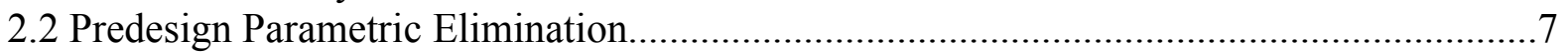

2.3 Energy Efficient Predesigns ..........................................................................................11

2.3.1 Energy Efficient Predesign \#1 ...........................................................................11

2.3.2 Energy Efficient Predesign \#2 ……………......................................................12

2.3.3 Energy Efficient Predesign \#3 ........................................................................12

2.3.4 Energy Efficient Predesign \#4 ........................................................................12

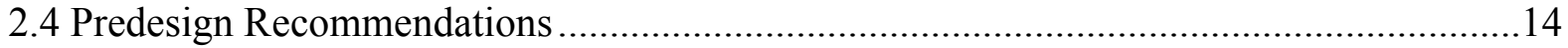

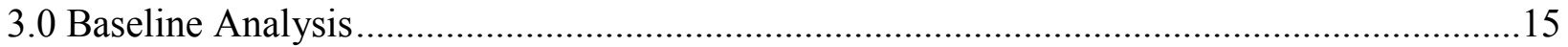

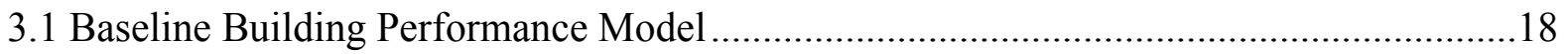

3.2 Baseline Energy Model........................................................................................... 19

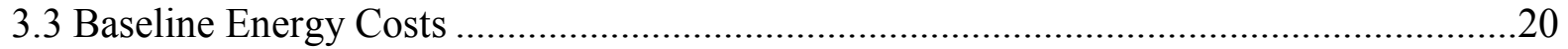

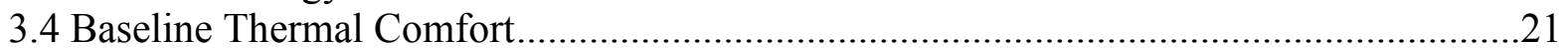

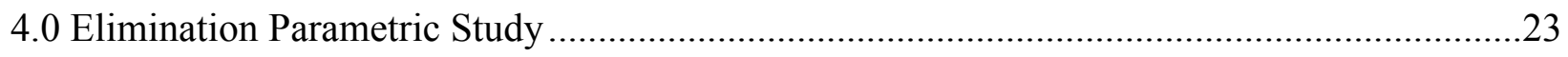

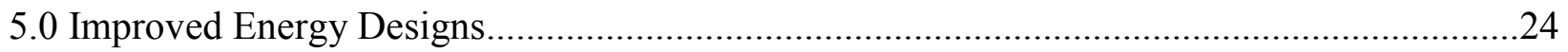

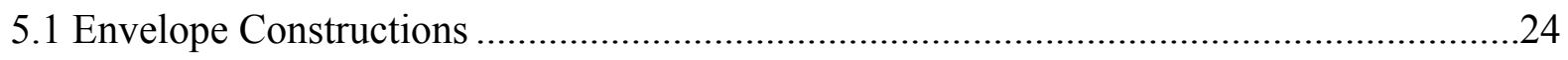

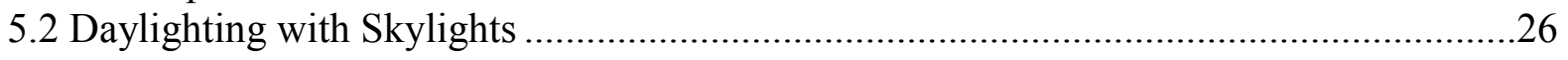

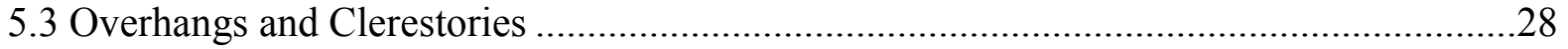

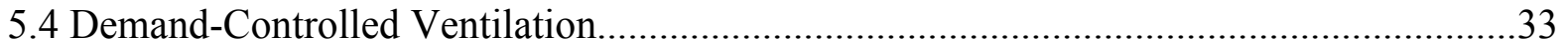

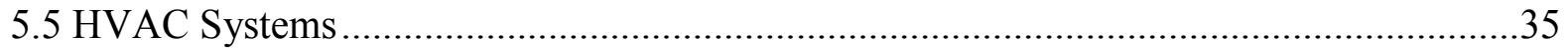

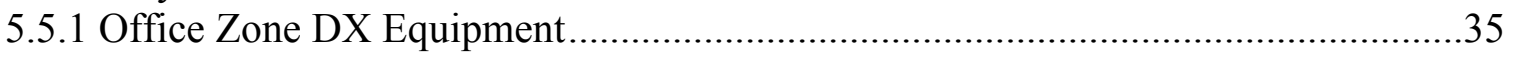

5.5.2 Garage Zone Heater/Ventilators ..........................................................................37

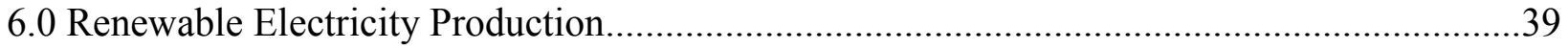

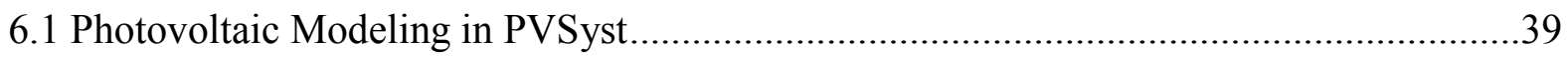

6.2 Photovoltaic Modeling in EnergyPlus ……………........................................................42

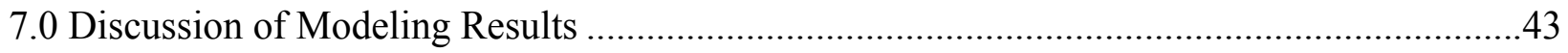

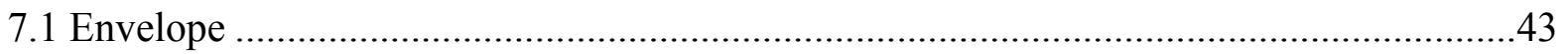

7.2 Daylighting with Skylights ..................................................................................... 44 


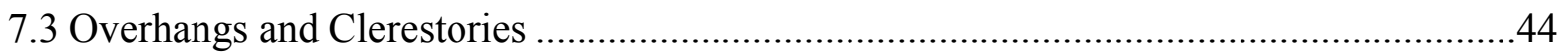

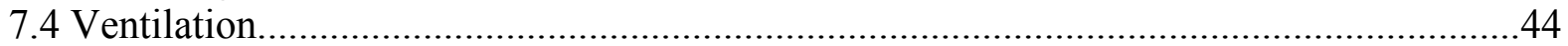

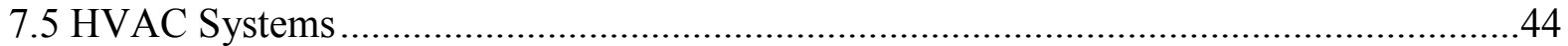

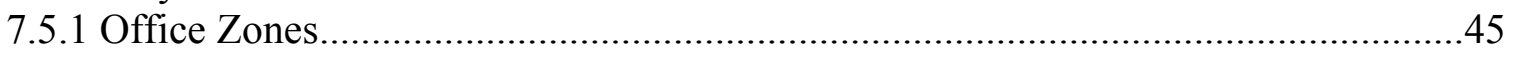

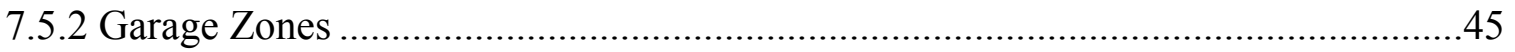

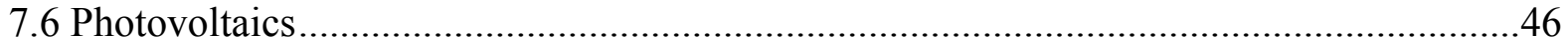

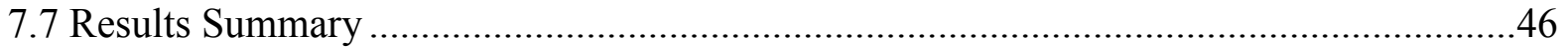

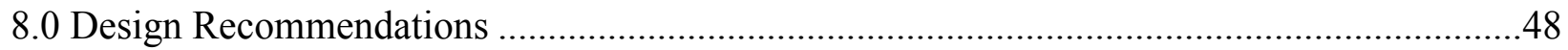

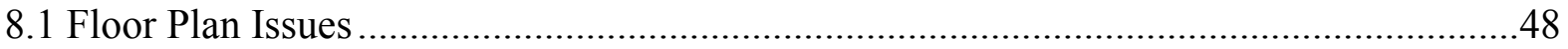

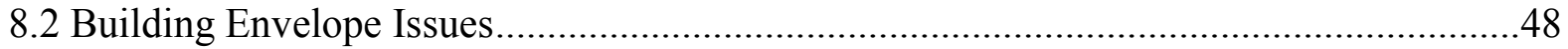

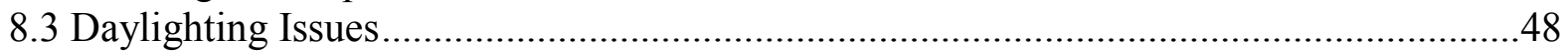

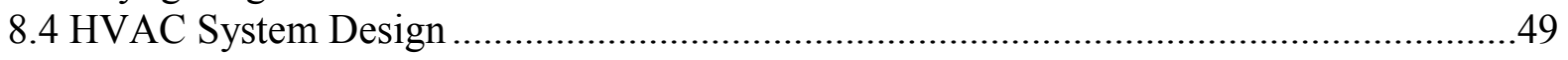

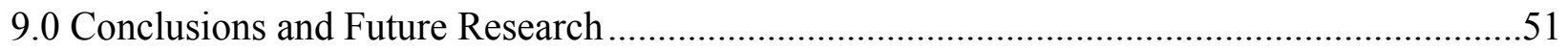

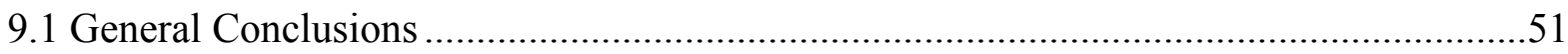

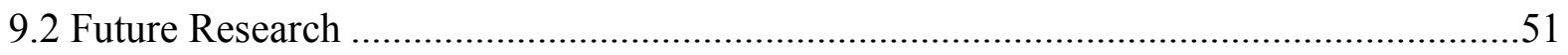

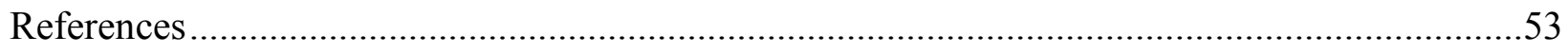

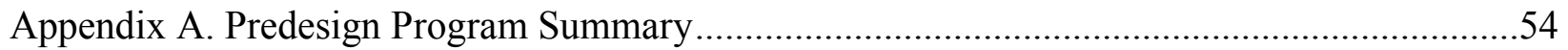

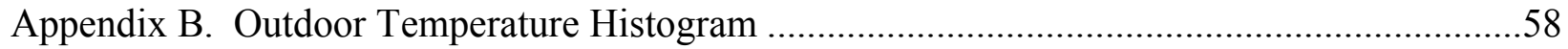

Appendix C. EnergyPlus Input Files …………………...................................................

Appendix D. Economic Modeling of EnergyPlus Results............................................................61

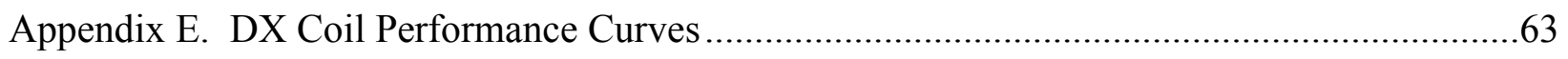

Appendix F. Comparison of DOE-2.1E and EnergyPlus .........................................................68 


\section{List of Tables}

Table 1-1. Nine-Step Design Process for Designing and Constructing Energy Efficient Buildings .......... 3

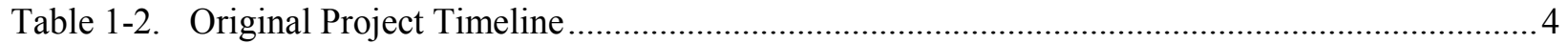

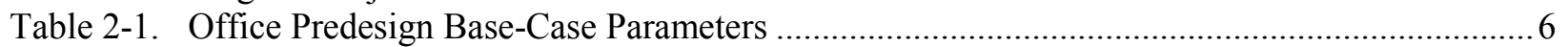

Table 2-2. Office Predesign Base-Case Annual Energy Use and Costs ............................................... 7

Table 2-3. Parametric Study Results for Energy Use for Predesign Dayshift Offices ........................... 8

Table 2-4. Parametric Study Results for Energy Cost for Predesign Dayshift Offices ............................ 9

Table 2-5. Heat Recovery, Night Ventilation, Daylighting, and EE \#1 Energy Cost Analysis for

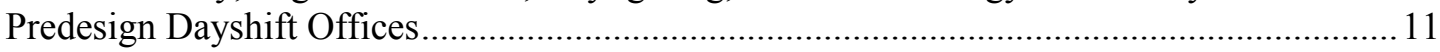

Table 2-6. Base-Case Energy Costs Compared with Energy Efficient Predesigns ................................ 12

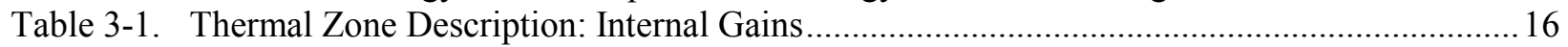

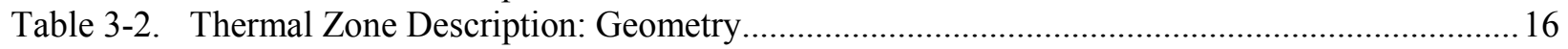

Table 3-3. Envelope Specifications for Baseline Models per ASHRAE 90.1-2001 ….......................... 17

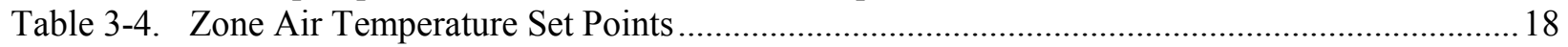

Table 3-5. Baseline Building Performance Model Results for Energy Use ......................................... 19

Table 3-6. Baseline Building Performance Model Results for Peak Loads............................................ 19

Table 3-7. Baseline Energy Model Results for Energy Use ................................................................20

Table 3-8. Baseline Energy Model Results for Energy Costs............................................................2

Table 3-9. Summary of Baseline Performance Model Predictions for Occupant Thermal Comfort on ASHRAE Thermal Sensation Scale for Uncooled Garages and Shops..................................2 21

Table 3-10. Summary of Baseline Building Performance Model Predictions for Occupant Thermal Comfort on ASHRAE Thermal Sensation Scale for Heating in 24-Hour Offices ...................22

Table 3-11. Summary of Baseline Energy Model Predictions for Occupant Thermal Comfort on ASHRAE Thermal Sensation Scale for 24-Hour Office and Garage ....................................22

Table 4-1. Summary of Baseline Parametric Study by Type of Zone .................................................22

Table 5-1. Envelope Thermal Performance Levels ......................................................................25

Table 5-2. Summary of Results for Energy Use and Peak Loads: Envelope Change Models ................25

Table 5-3. Summary of Occupant Thermal Comfort Predictions on ASHRAE Thermal Sensation Scale for Uncooled Garages and Shops: Envelope Change Models ...............................................26

Table 5-4. Summary of Occupant Thermal Comfort Predictions on ASHRAE Thermal Sensation Scale for Heating in 24-Hour Offices: Envelope Change Models .................................................26

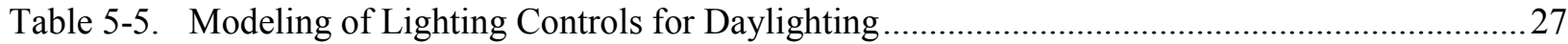

Table 5-6. Summary of Results for Energy Use and Peak Loads:........................................................27

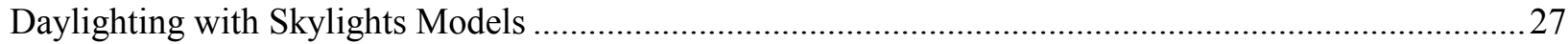

Table 5-7. Summary of Occupant Thermal Comfort Predictions on ASHRAE Thermal Sensation Scale for Uncooled Garages and Shops: Daylighting with Skylights Model ..................................28

Table 5-8. Summary of Occupant Thermal Comfort Predictions on ASHRAE Thermal Sensation Scale for Heating in 24-Hour Offices: Daylighting with Skylights Model......................................28

Table 5-9. Summary of Results for Energy Use and Peak Loads: Overhangs and Clerestories Model ... 32

Table 5-10. Summary of Occupant Thermal Comfort Predictions on ASHRAE Thermal Sensation Scale for Uncooled Garages and Shops: Overhangs and Clerestories Model................................... 32

Table 5-11. Summary of Occupant Thermal Comfort Predictions on ASHRAE Thermal Sensation Scale for Heating in 24-Hour Offices: Overhangs and Clerestories Model..................................... 33

Table 5-12. Summary of Results for Energy and Load in Demand-Controlled Garage/Shop/ARFF Spaces 
Table 5-13. Summary of Predictions for Occupant Thermal Comfort on ASHRAE Thermal Sensation Scale for Uncooled Garages and Shops: Demand-Controlled Ventilation and Baseline Performance Model....

Table 5-14. Summary of Results for Energy Use for Office Zones with Constant-Volume DX RooftopPackaged Units

Table 5-15. Summary of Results for Energy Cost for Office Zones with Constant-Volume DX RooftopPackaged Units

Table 5-16. Summary of Predictions for Occupant Thermal Comfort on ASHRAE Thermal Sensation Scale for 24-Hour Office: ZN1

Table 5-17. Summary of Results for Energy Use in Garage Zones........................................................37

Table 5-18. Summary of Energy Cost Results for Garage Zones.

Table 5-19. Summary of Predictions for Occupant Thermal Comfort on ASHRAE Thermal Sensation Scale for 24-Hour Garages: ZN3.

Table 6-1. Summary of Predicted PV Performance by Month: $32^{\circ}$ Tilt .............................................. 41

Table 7-1. Summary of Results for Energy Use for Entire Building .....................................................47

Table 7-2. Summary of Results for Energy Cost for Entire Building ...................................................47

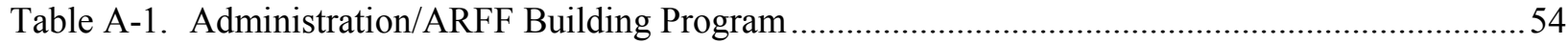

Table C-1. Selected EnergyPlus Input Files Available from Modeling Effort.......................................59

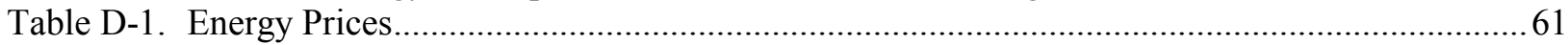

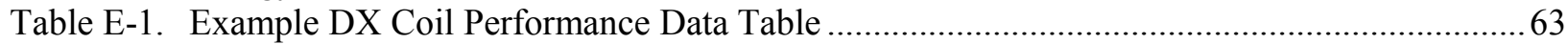

Table F-1. DOE-2.1E Whole Building Elimination Results Summary ….............................................69

Table F-2. EnergyPlus Whole Building Elimination Results Summary ...............................................70 


\section{List of Figures}

Figure 2-1. Predesign base-case zone diagram ............................................................................ 7

Figure 2-2. Parametric study results for energy use for predesign dayshift offices ................................. 8

Figure 2-3. Parametric study results for energy cost for predesign dayshift offices ................................9

Figure 2-4. Lighting and HVAC energy cost comparison for base-case and energy efficient predesigns 13

Figure 2-5. Base-case lighting and HVAC energy costs by category .................................................. 13

Figure 2-6. EE \#4 lighting and HVAC costs with savings from base case ......................................... 13

Figure 3-1. Thermal zones used in design development models ........................................................ 17

Figure 3-2. Weekday schedules for occupancy, lighting, and equipment............................................ 18

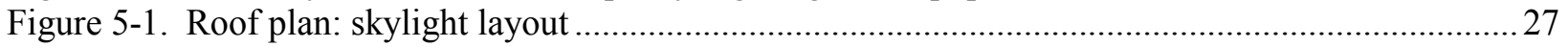

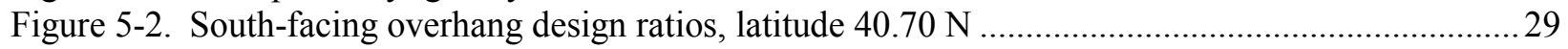

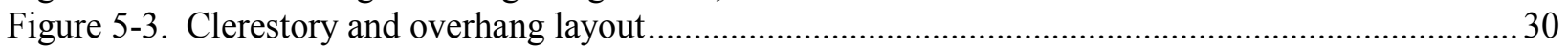

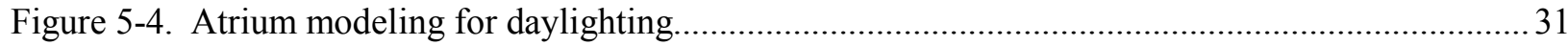

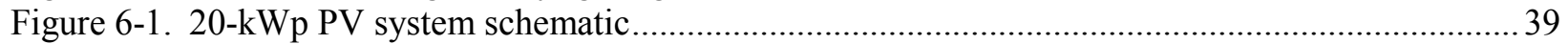

Figure 6-2. Current-voltage curves of system losses and performance at expected envir. conditions....... 40

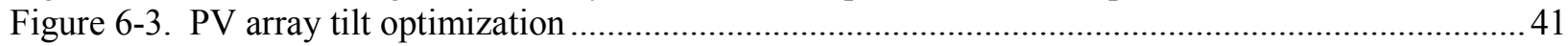

Figure 6-4. Global horizontal insolation histogram by season............................................................ 42

Figure B-1. Typical year outdoor temperature histogram ...................................................................5

Figure E-1. Plot of example of biquadratic curve for capacity as a function of temperatures .................. 64

Figure E-2. Plot of example of biquadratic curve for energy input ratio as a function of temperatures .... 65

Figure E-3. Plot of an example quadratic performance curve for capacity as a function of flow rate .......66

Figure E-4. Plot of an example quadratic performance curve for energy input ratio as a function of flow

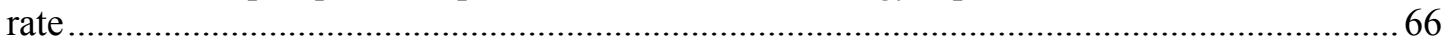

Figure F-1. DOE-2 results for parametric elimination study of proposed Teterboro Airport Building .... 68

Figure F-2. EnergyPlus results for parametric elimination study of proposed Teterboro Airport Building. 


\section{Acronyms}

\begin{tabular}{|c|c|}
\hline $\mathrm{AC}$ & alternating current \\
\hline $\mathrm{ACH}$ & air changes per hour \\
\hline ASHRAE & American Society of Heating, Refrigerating, and Air-Conditioning Engineers \\
\hline $\mathrm{CO}_{2}$ & carbon dioxide \\
\hline $\mathrm{COP}$ & coefficient of performance \\
\hline $\mathrm{CV}$ & constant volume air system \\
\hline DC & direct current \\
\hline DHW & domestic hot water \\
\hline DOE & U.S. Department of Energy \\
\hline $\mathrm{DX}$ & direct expansion, electric air-to-air cooling equipment \\
\hline EIR & energy input ratio, inverse of COP \\
\hline GSHP & ground source heat pump \\
\hline $\mathrm{HPBi}$ & High-Performance Building research initiative (DOE) \\
\hline HRV & heat recovery ventilator \\
\hline HVAC & heating, ventilating, and air-conditioning \\
\hline IAQ & indoor air quality \\
\hline IGU & insulated glazing unit \\
\hline IP & inch-pound (unit) \\
\hline NREL & National Renewable Energy Laboratory \\
\hline PANYNJ & Port Authority of New York and New Jersey \\
\hline PLF & part load factor \\
\hline PLR & part load ratio \\
\hline PMV & predicted mean vote \\
\hline PV & photovoltaics \\
\hline SHGC & solar heat gain coefficient \\
\hline TMY & typical meteorological year \\
\hline TMY2 & typical meteorological year, updated format \\
\hline VAV & variable air volume system \\
\hline
\end{tabular}




\section{Acknowledgments}

The authors would like to thank reviewers Tom Wood, Drury Crawley, and Sheila Hayter for their efforts and helpful comments.

The U.S. Department of Energy's High-Performance Buildings Research initiative (Office of Building Technologies) and the Photovoltaics (PV) for Buildings task (Office of Solar Energy Technology) supplied funding. The High Performance Buildings Research Initiative supported the energy design analysis reported here, and the PV for Buildings task supported the PV system analysis. 


\section{Executive Summary}

The High Performance Buildings Research group at the National Renewable Energy Laboratory conducts research for the U.S. Department of Energy's High Performance Building initiative (HPBi), which focuses on greatly reducing energy use in commercial buildings. Actual buildings are used as case studies so that investigators can explore how "whole-building" and "system-integration" issues related to energy efficiency play out in the real world. A new/proposed building for the Teterboro Airport, just north of Newark, New Jersey, was selected as a case study for HPBi research efforts. This report documents research-level energy analysis conducted on the Teterboro Airport building during predesign and design phases of the project. The report's goals are

- To provide specific analysis and recommendations intended to help the Teterboro Airport building achieve a goal of reducing energy cost by $50 \%$ or more compared to an equivalent codecompliant building

- To demonstrate analysis methodologies that are generally useful for designing extremely efficient commercial buildings

- To present examples of using EnergyPlus to conduct such analyses.

The design analysis involved the extensive use of computer simulations. An early simulation study, prepared during the predesign stage, was based on a two-story, solar-neutral building with a square floor plan and uniform glazing on all sides that could meet the program needs for office-type space. Using the program DOE-2.1E, we developed and modeled an energy efficient predesign. This analysis predicted a $44 \%$ reduction in energy cost over the base-case office building, which just met American Society of Heating, Refrigerating, and Air-Conditioning Engineers (ASHRAE) Energy Standard 90.1-1999. The project's architects generated a proposed design, termed the Stage One design (dated December 14, 2001), which was subsequently analyzed using EnergyPlus to conduct extensive whole-building, annual energy simulations (Crawley 2001). The baseline model for this stage differed from the predesign base case in that it used the actual proposed building plan and enclosure designed to just meet ASHRAE 90.12001 (proposed informational Appendix [g]) requirements, rather than a square, 90.1-1999-compliant building).

The design analysis showed that energy costs for conditioning, lighting, and ventilating offices could be reduced by $50.5 \%$ compared to a baseline building. For garage, shop, and maintenance spaces, energy costs for heating, lighting, and ventilating could be reduced by $48.3 \%$ compared to the baseline building. On an area basis, the overall energy use could be decreased from a baseline intensity of $245 \mathrm{kWh} / \mathrm{m}^{2} \cdot \mathrm{yr}$ $\left(77.7 \mathrm{kBtu} / \mathrm{ft}^{2} \cdot \mathrm{yr}\right)$ to $79 \mathrm{kWh} / \mathrm{m}^{2} \cdot \mathrm{yr}\left(25 \mathrm{kBtu} / \mathrm{ft}^{2} \cdot \mathrm{yr}\right)$. Energy cost intensity could be reduced from $\$ 25.0 / \mathrm{m}^{2} \cdot \mathrm{yr}\left(\$ 2.32 / \mathrm{ft}^{2} \cdot \mathrm{yr}\right)$ to $\$ 12.7 / \mathrm{m}^{2} \cdot \mathrm{yr}\left(\$ 1.18 / \mathrm{ft}^{2} \cdot \mathrm{yr}\right)$. In this report, we show how these savings can be obtained by presenting results of energy models. In addition, we make specific design recommendations for the Teterboro Airport building, which include:

- Implementing aggressive daylighting design and lighting reductions.

- Using high-performance glazing systems.

- Adding skylights, clerestories, and overhangs.

- Downsizing heating, ventilating, and air-conditioning (HVAC) equipment.

- Adding heat recovery ventilation equipment.

- Implementing demand-controlled ventilation.

- Using variable air volume (VAV) air systems.

- Selecting high-efficiency cooling equipment. 
Occupant thermal comfort is also quantified, and the results show that energy savings can be obtained at the same time that occupant thermal comfort is improved.

We present the following general conclusions in this report:

- The goal of reducing building energy costs by 50\% compared to ASHRAE 90.1-2001(g) is attainable in a climate typical of the central East Coast of the United States for small to mediumsized commercial buildings with roughly half office and half light-industrial activities and partial 24-hour operation.

- Proposed informational Appendix (g) for ASHRAE Energy Standard 90.1-2001 is useful when calculating baseline energy use for determining energy savings.

- EnergyPlus has been developed to the point where it can be used to analyze building energy design for some, but not all, HVAC systems.

- The versatile capabilities of EnergyPlus for specifying schedules facilitate modeling demandcontrolled ventilation schemes.

We recommend the following additional energy analysis for the Teterboro Airport building:

- As designs evolve for the Teterboro Airport building, energy models should be continually updated to ensure that the impact on energy efficiency is understood.

- As designs evolve for interior layout, furniture, and finishes, accurate daylighting models should be developed to predict natural lighting levels and to assist with properly locating daylight sensors.

- Many efforts to model VAV HVAC packaged systems in EnergyPlus were unsuccessful. Further efforts to model VAV packaged systems are warranted because of the potential to reduce high fan energy and costs.

- Centralized ground source heat pump modeling is warranted.

- Nighttime ventilation precooling modeling is warranted.

- Airflow models of the type known as "multizone" could be applied to assess the effectiveness of passively ventilating the garage and shop spaces by leaving the garage doors open. This would save considerable fan power because the ventilation fans would be switched off.

- Heat recovery ventilation equipment needs to be modeled with lockout/bypassing because it is detrimental during free-cooling modes. 


\subsection{Introduction}

As part of the U.S. Department of Energy's (DOE) High Performance Building initiative (HPBi), the High Performance Buildings Research group at the National Renewable Energy Laboratory (NREL) conducts research focused on greatly reducing the energy use in commercial buildings. Actual building projects are used as case studies so that investigators can explore how "whole-building" and "system integration" issues related to energy efficiency play out in the real world. A new/proposed building for the Teterboro Airport, located just north of Newark, New Jersey, was selected as a case study for research. For buildings that are not yet built, research focuses on changing the process by which buildings are designed. Part of this process change involves the extensive use of building energy simulation during the design phase, which offers designers energy-related data that can help them to understand the consequences of design decisions.

\subsection{Design Process}

The group's research focuses on the process by which an energy efficient commercial building can be designed, built, and operated. Encouraging the adoption of a process that has a better chance of producing energy efficient buildings is important because the conventional design process has not done an adequate job of integrating existing technologies. Hayter et al. (2000) describes an energy efficient design process in the nine steps listed in Table 1-1. In this report, we give examples of using energy simulation during predesign and design development phases, and document how steps 1 through 6 in Table 1-1 were applied to the new building for Teterboro Airport.

Table 1-1. Nine-Step Energy Design Process for Designing and Constructing Energy Efficient Buildings

\begin{tabular}{|c|c|}
\hline \multirow[t]{3}{*}{ Predesign } & $\begin{array}{l}\text { STEP 1. CREATE A BASE-CASE BUILDING MODEL TO QUANTIFY BASE-CASE ENERGY USE } \\
\text { AND COSTS. THE BASE-CASE BUILDING IS SOLAR NEUTRAL (EQUAL GLAZING AREAS ON } \\
\text { ALL WALL ORIENTATIONS) AND MEETS THE REQUIREMENTS OF APPLICABLE ENERGY } \\
\text { EFFICIENCY CODES SUCH AS ASHRAE }{ }^{*} \text { STANDARDS } 90.1 \text { AND } 90.2 \text {. }\end{array}$ \\
\hline & $\begin{array}{l}\text { STEP 2. COMPLETE A PARAMETRIC ANALYSIS TO DETERMINE SENSITIVITIES TO SPECIFIC } \\
\text { LOAD COMPONENTS. SEQUENTIALLY ELIMINATE LOADS, SUCH AS CONDUCTIVE LOSSES, } \\
\text { LIGHTING LOADS, SOLAR GAINS, AND PLUG LOADS, FROM THE BASE-CASE BUILDING. }\end{array}$ \\
\hline & $\begin{array}{l}\text { STEP 3. DEVELOP PRELIMINARY DESIGN SOLUTIONS. THE DESIGN TEAM BRAINSTORMS } \\
\text { POSSIBLE SOLUTIONS THAT MAY INCLUDE STRATEGIES TO REDUCE LIGHTING AND } \\
\text { COOLING LOADS BY INCORPORATING DAYLIGHTING OR TO MEET HEATING LOADS WITH } \\
\text { PASSIVE SOLAR HEATING. }\end{array}$ \\
\hline \multirow[t]{2}{*}{$\begin{array}{l}\text { Schematic } \\
\text { Design }\end{array}$} & $\begin{array}{l}\text { STEP 4. INCORPORATE PRELIMINARY DESIGN SOLUTIONS INTO A COMPUTER MODEL OF } \\
\text { THE PROPOSED BUILDING DESIGN. ENERGY IMPACT AND COST EFFECTIVENESS OF EACH } \\
\text { VARIANT IS DETERMINED BY COMPARING THE ENERGY WITH THE ORIGINAL BASE-CASE } \\
\text { BUILDING AND TO THE OTHER VARIANTS. THOSE VARIANTS WITH THE MOST FAVORABLE } \\
\text { RESULTS SHOULD BE INCORPORATED INTO THE BUILDING DESIGN. }\end{array}$ \\
\hline & StEP 5. PREPARE PRELIMINARY SET OF CONSTRUCTION DRAWINGS. \\
\hline $\begin{array}{c}\text { Design } \\
\text { Development }\end{array}$ & $\begin{array}{l}\text { STEP 6. IDENTIFY AN HVAC }{ }^{\dagger} \text { SYSTEM THAT WILL MEET THE PREDICTED LOADS. THE } \\
\text { HVAC SYSTEM SHOULD WORK WITH THE BUILDING ENVELOPE AND EXPLOIT THE SPECIFIC } \\
\text { CLIMATIC CHARACTERISTICS OF THE SITE FOR MAXIMUM EFFICIENCY. OFTEN, THE HVAC } \\
\text { SYSTEM IS MUCH SMALLER THAN IN A TYPICAL BUILDING. }\end{array}$ \\
\hline $\begin{array}{l}\text { Construction } \\
\text { Documents } \\
\text { and Bid }\end{array}$ & $\begin{array}{l}\text { STEP 7. FINALIZE PLANS AND SPECIFICATIONS. ENSURE THAT THE BUILDING PLANS ARE } \\
\text { PROPERLY DETAILED AND THAT THE SPECIFICATIONS ARE ACCURATE. THE FINAL DESIGN } \\
\text { SIMULATION SHOULD INCORPORATE ALL COST-EFFECTIVE FEATURES. }\end{array}$ \\
\hline
\end{tabular}




\begin{tabular}{c|l}
\hline Construction & $\begin{array}{l}\text { STEP 8. RERUN SIMULATIONS BEFORE DESIGN CHANGES ARE MADE DURING } \\
\text { CONSTRUCTION. VERIFY THAT CHANGES WILL NOT ADVERSELY AFFECT THE BUILDING'S } \\
\text { ENERGY PERFORMANCE. }\end{array}$ \\
\hline Occupancy & STEP 9. COMMISSION ALL EQUIPMENT AND CONTROLS (A BUILDING THAT IS NOT \\
& PROPERLY COMMISSIONED WILL NOT MEET THE ENERGY EFFICIENCY DESIGN GOALS). \\
& EDUCATE BUILDING OPERATORS (BUILDING OPERATORS MUST UNDERSTAND HOW TO \\
& PROPERLY OPERATE THE BUILDING TO MAXIMIZE ITS PERFORMANCE). \\
\hline
\end{tabular}

ASHRAE: AmERICAN SOCIETY OF HEATING, REFRIGERATING, AND AIR-CONDITIONING ENGINEERS.

${ }^{\dagger}$ HVAC: HEATING, VENTILATING, AND AIR-CONDITIONING.

\subsection{Project Summary}

The Port Authority of New York and New Jersey (PANYNJ) is planning a new building for Teterboro Airport. The proposed building is a $3,542-\mathrm{m}^{2}\left(38,135-\mathrm{ft}^{2}\right)$ multiple-use building that houses administrative offices and maintenance shops. Appendix A contains a more detailed description of the program requirements. Croxton Collaborative Architects is the project architect, and PANYNJ is the engineer. NREL researchers performed extensive simulations to optimize the building envelope and mechanical systems. Weather data from the Newark, New Jersey, area show a climate with approximately 5000 heating degree-days (base $65^{\circ} \mathrm{F}$ ) and 3500 cooling degree-days (base $50^{\circ} \mathrm{F}$; see Appendix B for a histogram of outdoor dry-bulb temperatures).

HPBi has specified energy-related goals that must be a high project priority if researchers are to participate. HPBi research involvement provides the project with research-level energy analysis and design review. For humid climates, buildings need to incorporate a climate-sensitive design that reduces building energy costs by $50 \%$ when compared to a building that serves the same purpose but is built to just meet applicable code. Therefore, the energy-related goal for this project is to produce and operate a building with energy costs that are 50\% less than they would have been if the building were built to just meet ASHRAE 90.1-2001 (ASHRAE 2001). To judge whether this goal has been met, we adopt the methodology proposed in addendum (e) to ASHRAE standard 90.1-2001 (ASHRAE 2002), which is referred to as "90.1-2001(e)."

Table 1-2 gives an original approximate schedule for the project. However, the project is currently reported to be on hold. It is likely that the project will be delayed and that the building's programmatic requirements will be altered, making design changes necessary.

Table 1-2. Original Project Timeline

\begin{tabular}{llll}
\hline & Start & & End \\
\hline CONCEPTUAL DESIGN & $05 / 01$ & & $12 / 02$ \\
CONSTRUCTION PLANS & $01 / 03$ & $12 / 03$ & \\
CONSTRUCTION & $04 / 04$ & $06 / 05$ & \\
COMMISSIONING/MONITORING & $06 / 05$ & $06 / 07$ & \\
\hline
\end{tabular}

\subsection{Organization of Report}

The simulation-based analyses presented here discuss two cycles of energy simulation as part of the overall process of designing an extremely energy efficient building; as designs are refined, additional cycles of energy simulations should be performed. We summarize the first cycle in Section 2.0, which presents predesign material prepared for an early design charrette. This section provides an example of applying the first three steps listed in Table 1-1. In the rest of the document, we focus on a second cycle 
of energy analysis to support design development, where modeling is able to use the specifics of a proposed layout rather than a generic, solar-neutral building. Although Section 2.0 presents predesign analysis, the bulk of this report presents design analysis of a "Stage One" design (dated December 14, 2001) represented by architectural drawings received from the PANYNJ called Plan Scheme "A" and Enclosure Studies "A-2." This design analysis consists primarily of conducting extensive whole-building, annual energy simulations using the program EnergyPlus (Crawley et al. 2001).

The energy simulation design analysis presented in this report has the following steps:

1. Develop baseline building models using Scheme A or Enclosure Studies A-2 built to ASHRAE 90.1-2001 and modeled per proposed addendum (e)—see Section 3.0.

2. Perform an elimination parametric modeling study-see Section 4.0.

3. Investigate realistic efficiency improvements to the baseline-see Section 5.0. These include:

a. Thermal envelope improvements

b. Lighting/daylighting

c. Building shell changes (overhangs, clerestories)

d. Ventilation schemes

e. HVAC equipment efficiencies and sizing.

Section 6.0 presents the results of computer simulations of the overall system performance that might be expected with solar electric systems for the Teterboro Airport building. In Section 7.0, we discuss the modeling results. Section 8.0 summarizes the design recommendations for the proposed Teterboro Airport building based on simulation results and on the opinions of the HPBi team of researchers. In Section 9.0, we draw general conclusions from this design analysis that may be applicable to design and predesign efforts on future buildings. Appendices A through F contain supporting information and expanded detail on subjects including the building's programmatic needs, computing energy costs, cooling coil performance curves, and EnergyPlus input files. 


\subsection{Predesign Energy Simulations and Review of Office Areas}

This section summarizes the contents of an earlier draft report that is summarized in Chapter 2.0 that was prepared for a design charette held on August 2, 2001. This analysis focused only on the office areas of the building. Thermal, daylighting, and cost analyses presented in this section were performed using the building energy analysis program DOE-2.1E, Version 107 (Winkelmann et al. 1993). DOE-2.1E is an hourly simulation tool designed to evaluate building system and envelope performances. In the other sections of this report, we report the results from using a newer building simulation tool, called EnergyPlus. Because DOE-2.1E uses inch-pound (IP) units, IP units are used in this section. The rest of this report uses metric or SI units.

\subsection{Base-Case Analysis}

The project team developed a base-case model to meet the requirements of ASHRAE Energy Standard 90.1-1999. Table 2-1 shows the parameters used for the base case.

Table 2-1. Office Predesign Base-Case Parameters

\begin{tabular}{|c|c|}
\hline PARAMETER & VALUE \\
\hline WINDOW AREA/GROSS WALL AREA & $38 \%$ \\
\hline WALL R-VALUE $\left(\mathrm{FT}^{2} \cdot{ }^{\circ} \mathrm{F} \cdot \mathrm{HR} / \mathrm{BTU}\right)$ & 5.7 \\
\hline ROOF R-VALUE (FT $\left.{ }^{2} \cdot{ }^{\circ} \mathrm{F} \cdot \mathrm{HR} / \mathrm{BTU}\right)$ & 15 \\
\hline WINDOW U-VALUE (BTU/ $\left.\mathrm{FT}^{2} \cdot{ }^{\circ} \mathrm{F} \cdot \mathrm{HR}\right)$ & 0.57 \\
\hline WINDOW SHADING COEFFICIENT & 0.62 \\
\hline SLAB EFFECTIVE R-VALUE ( $\left(\mathrm{FT}^{2} \cdot{ }^{\circ} \mathrm{F} \cdot \mathrm{HR} / \mathrm{BTU}\right)$ & 25 \\
\hline OCCUPANCY (FT²/PERSON) & 100 \\
\hline EQUIPMENT DENSITY (W/FT $\left.{ }^{2}\right)$ & 1.0 \\
\hline LIGHTING DENSITY (W/FT $\left.{ }^{2}\right)$ & 1.3 \\
\hline Sensible HeAt Gain (BTU/HR·PERSON) & 250 \\
\hline LATENT HEAT GAIN (BTU/HR·PERSON) & 150 \\
\hline CHILLER COP* & 4.2 \\
\hline BOILER EFFICIENCY & $80 \%$ \\
\hline
\end{tabular}

The base-case building is a two-story, square, solar-neutral box with a 7,569- $\mathrm{ft}^{2}$ footprint. In this initial analysis, we focused on the administrative offices. The windows for the base case are 4.5 feet high and wrap continuously around each floor. We used a variable air volume (VAV) system with zone reheat, central boiler and chiller, return air through the plenum, and an economizer. A core zone was placed on each floor with a 15-foot-deep perimeter zone on each side of the building. Figure 2-1 illustrates the basic HVAC zone layout for each floor of the solar-neutral model. 
Perimeter Zones

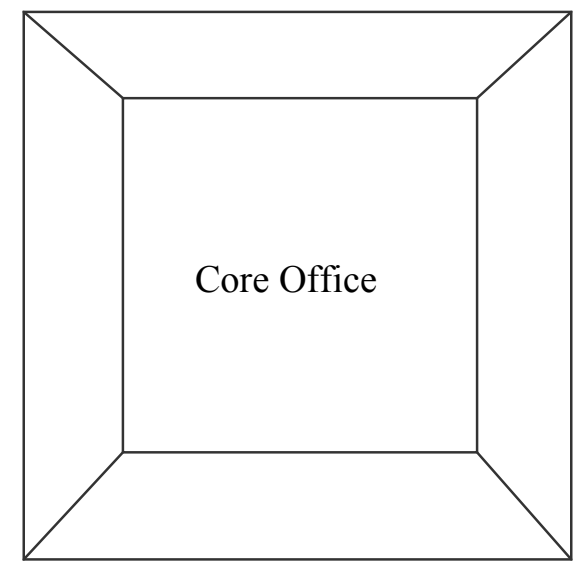

Figure 2-1. Predesign base-case zone diagram

The base-case model does not use any daylighting or shading devices. Occupancy, lighting, and equipment schedules were based on the building being primarily occupied on weekdays between 8:00 A.M. and 5:00 P.M. Infiltration was set at a constant rate of 0.2 air changes per hour (ACH) during unoccupied periods and zero ACH during occupied periods because of building pressurization. We obtained rate schedules for buildings with similar load requirements from Public Service Electric and Gas Company (which serves New Jersey) and used these for simulating typical electric and natural gas costs. Appendix D contains the costs used in the analysis. Table 2-2 lists the base-case energy consumption by load, along with their related costs.

Table 2-2. Office Predesign Base-Case Annual Energy Use and Costs

\begin{tabular}{llll}
\hline & $\begin{array}{c}\text { Energy Use } \\
\text { (kBTU/yr) }\end{array}$ & $\begin{array}{c}\text { Energy Cost } \\
\text { (\$/yr) }\end{array}$ & $\begin{array}{c}\text { Percentage } \\
\text { of Total } \\
\text { Cost }\end{array}$ \\
\hline LIGHTS & 207 & 6,950 & 30 \\
PLUGS & 159 & 5,346 & 23 \\
HEATING & 241 & 2,238 & 10 \\
COOLING & 124 & 6,267 & 27 \\
PUMPS & 11 & & \\
FANS & 45 & 1,928 & 8 \\
DHWW & 64 & 421 & 2 \\
FIXED CosTS & & 115 & 0.5 \\
\hline TOTAL & 851 & 23,265 & \\
DHW: domestic hot water &
\end{tabular}

\subsection{Predesign Parametric Elimination}

To determine which variables have the greatest impact on the building's heating, cooling, and total energy consumption, we zeroed out basic components of the building loads. Figures 2-2 and 2-3 and Tables 2-3 and 2-4 summarize the results of the parametric elimination. 


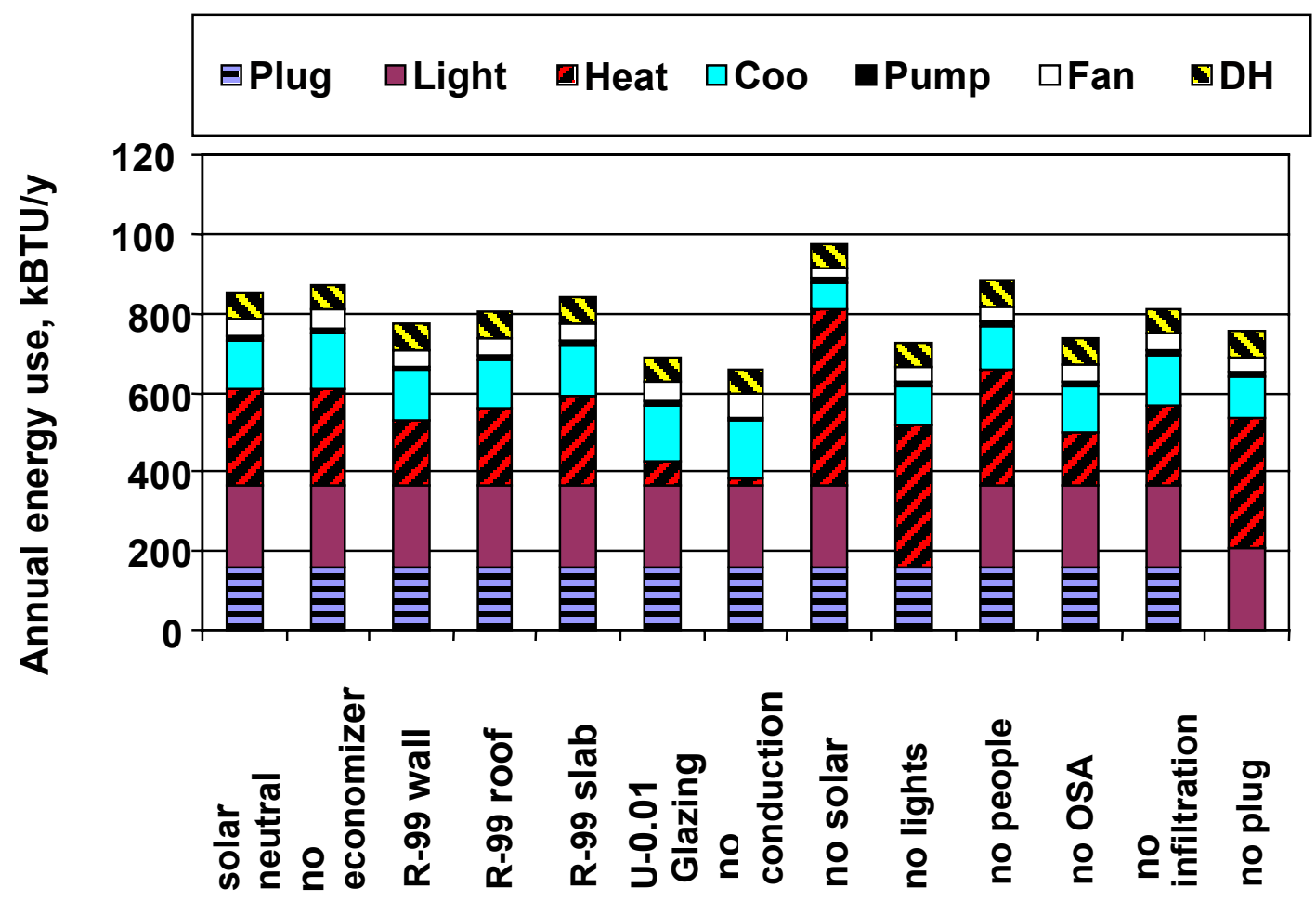

Figure 2-2. Parametric study results for energy use for predesign dayshift offices

Table 2-3. Parametric Study Results for Energy Use for Predesign Dayshift Offices

\begin{tabular}{|c|c|c|c|c|c|c|c|c|c|c|}
\hline & \multicolumn{8}{|c|}{ Operating Energy Use } & \multirow[b]{2}{*}{ kBTU/yr } & \multirow[b]{2}{*}{$\%$} \\
\hline & Plug & Lighting & Heating & Cooling & Pump & Fan & DHW & Total & & \\
\hline BASE CASE & 159 & 207 & 241 & 124 & 11 & 45 & 64 & 851 & 56,229 & \\
\hline NO ECONOMIZER & 159 & 207 & 242 & 144 & 12 & 45 & 64 & 873 & 57,696 & -3 \\
\hline R-99 WALL & 159 & 207 & 165 & 124 & 10 & 44 & 64 & 773 & 51,064 & 9 \\
\hline R-99 Roof & 159 & 207 & 193 & 124 & 10 & 45 & 64 & 802 & 52,953 & 6 \\
\hline R-99 SLAB & 159 & 207 & 223 & 128 & 11 & 46 & 64 & 839 & 55,404 & 1 \\
\hline U-0.01 GLAZING & 159 & 207 & 63 & 138 & 9 & 50 & 64 & 691 & 45,627 & 19 \\
\hline NO CONDUCTION & 159 & 207 & 19 & 144 & 8 & 59 & 64 & 660 & 43,566 & 23 \\
\hline $\begin{array}{l}\text { No SOLAR }\left(\mathrm{SC}^{*}=\right. \\
0)\end{array}$ & 159 & 207 & 445 & 66 & 10 & 26 & 64 & 976 & 64,474 & -15 \\
\hline NO LIGHTS & 159 & 0 & 358 & 98 & 11 & 35 & 64 & 725 & 47,913 & 15 \\
\hline NO PEOPLE & 159 & 207 & 290 & 110 & 11 & 40 & 64 & 881 & 58,178 & -3 \\
\hline No OSA** & 159 & 207 & 131 & 118 & 10 & 46 & 64 & 735 & 48,520 & 14 \\
\hline NO INFILTRATION & 159 & 207 & 202 & 126 & 10 & 45 & 64 & 814 & 53,746 & 4 \\
\hline NO PLUG & 0 & 207 & 330 & 104 & 11 & 37 & 64 & 752 & 49,676 & 12 \\
\hline
\end{tabular}




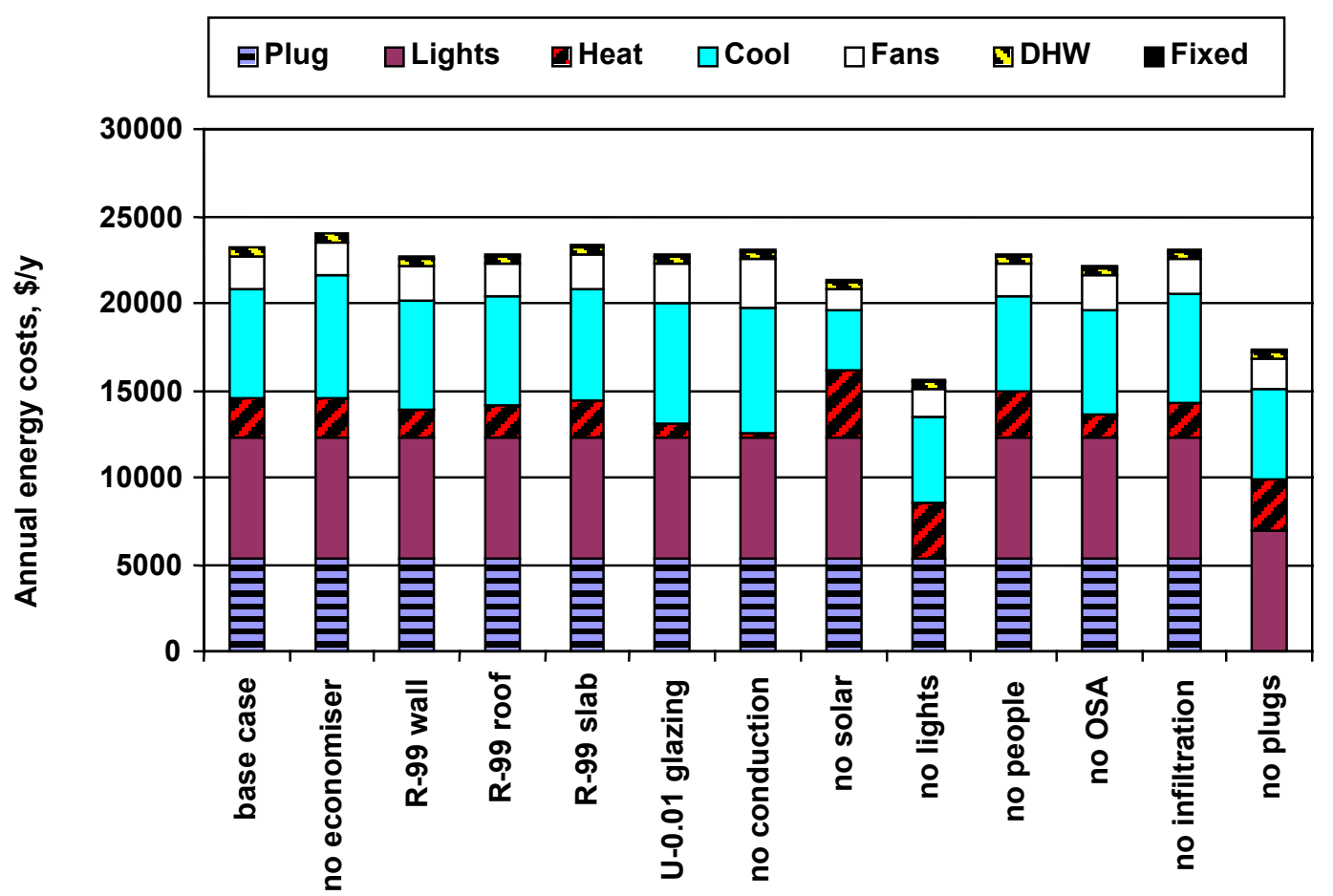

Figure 2-3. Parametric study results for energy cost for predesign dayshift offices

Table 2-4. Parametric Study Results for Energy Cost for Predesign Dayshift Offices

\begin{tabular}{|c|c|c|c|c|c|c|c|c|c|c|}
\hline & \multicolumn{8}{|c|}{ Energy Operating Costs } & \multirow{2}{*}{$\begin{array}{c}\$ I \\
\mathrm{ft}^{2} \cdot \mathrm{yr}\end{array}$} & \multirow{2}{*}{$\begin{array}{c}\% \\
\text { Difference } \\
\text { from } \\
\text { Base } \\
\text { Case }\end{array}$} \\
\hline & Plug & Lighting & Heating & Cooling & Pump & Fan & DHW & Total & & \\
\hline BASE CASE & 5346 & 6950 & 2238 & 6267 & 1928 & 421 & 115 & 23,265 & 1.54 & - \\
\hline $\begin{array}{l}\text { No } \\
\text { ECONOMIZER }\end{array}$ & 5346 & 6950 & 2249 & 7028 & 1944 & 421 & 115 & 24,053 & 1.59 & -3.4 \\
\hline R-99 WALL & 5346 & 6950 & 1629 & 6270 & 1902 & 421 & 115 & 22,633 & 1.50 & 2.7 \\
\hline R-99 Roof & 5346 & 6950 & 1856 & 6246 & 1905 & 421 & 115 & 22,839 & 1.51 & 1.8 \\
\hline R-99 SLAB & 5346 & 6950 & 2098 & 6454 & 1992 & 421 & 115 & 23,376 & 1.54 & -0.5 \\
\hline $\begin{array}{l}\text { U-0.01 } \\
\text { GLAZING }\end{array}$ & 5346 & 6950 & 768 & 6954 & 2215 & 421 & 115 & 22,769 & 1.50 & 2.1 \\
\hline $\begin{array}{l}\text { No } \\
\text { CONDUCTION }\end{array}$ & 5346 & 6950 & 211 & 7281 & 2692 & 421 & 115 & 23,016 & 1.52 & 1.1 \\
\hline $\begin{array}{l}\text { NO SOLAR } \\
(S C=0)\end{array}$ & 5346 & 6950 & 3883 & 3361 & 1268 & 421 & 115 & 21,344 & 1.41 & 8.3 \\
\hline NO LIGHTS & 5346 & 0 & 3134 & 5006 & 1583 & 421 & 115 & 15,605 & 1.03 & 32.9 \\
\hline NO PEOPLE & 5346 & 6950 & 2606 & 5559 & 1749 & 421 & 115 & 22,746 & 1.50 & 2.2 \\
\hline No OSA & 5346 & 6950 & 1342 & 5987 & 1952 & 421 & 115 & 22,113 & 1.46 & 5.0 \\
\hline $\begin{array}{l}\text { No } \\
\text { INFILTRATION }\end{array}$ & 5346 & 6950 & 1919 & 6342 & 1939 & 421 & 115 & 23,032 & 1.52 & 1.0 \\
\hline No PLugs & 0 & 6950 & 2921 & 5254 & 1648 & 421 & 115 & 17,309 & 1.14 & 25.6 \\
\hline
\end{tabular}

Variables examined for the predesign parametric elimination included: 
- Base case. ASHRAE Energy Standard 90.1-1999 compliant building. A solar-neutral box with equivalent floor area as building program description (day-shift office areas only).

- No economizer. Turn off the economizer and set outside air requirement to a fixed flow rate. This elimination increased the cooling loads by $16 \%$.

- $\quad$ R-99 wall. Increase the wall insulation to R-99.

- R-99 roof. Increase the roof insulation to R-99.

- R-99 slab. Increase the slab insulation to R-99.

- U-0.01 glazing. Decrease the glass conductance to U-0.01.

- No conduction. The cumulative effects of all R-99 envelope and U-0.01 glazing. These alternatives determine the building's sensitivity to the insulating value of the envelope components. Although eliminating heat flow through the building envelope all but eliminated the heating loads, the increase in cooling loads offset most of the potential savings. This indicates that cooling loads are present when the outdoor temperature is less than the inside temperature. Using better economizer controls strategies should minimize this impact. Heating energy costs are $10 \%$ of the total energy costs for the building. Occupant comfort is an important factor here, and consideration should be given to increasing envelope insulation to avoid cold spots around the perimeter. Increasing the thermal integrity of the envelope can potentially eliminate perimeter heating systems.

- No solar. Eliminate solar gain through the fenestration. This alternative resulted in an increase in energy use resulting from the increase in heating loads, but lowered energy costs because of the reduction in cooling energy required. This indicates that window shading will be an important factor, and that the shading coefficient of the glazing should be optimized by exposure to take advantage of passive solar applications without causing additional cooling loads. Overhangs may be useful for meeting this objective.

- No lights. Eliminate internal gains from the lighting system. This alternative significantly decreased the cooling energy requirement as well as the total energy use, but it had a negative impact on the building heating energy. Daylighting technologies will reduce the internal gains and electricity costs, and more efficient means of heating the building can be found. Additional heat for replacing that generated by lights is much smaller than the total lighting load, which makes daylighting a strong candidate for reducing energy consumption.

- No people. Eliminate internal gains that result from people. When the occupants were eliminated, the heating load increased and the cooling load decreased. The small change indicates minimal impact from internal latent and sensible people loads.

- No outside air. Eliminate the outside air intake. This alternative considerably reduced heating requirements, indicating that a heat recovery system may be a viable option for reducing energy use and costs.

- No infiltration. Eliminate the infiltration. Building infiltration is assumed to be low here because of pressurization, but it does affect the energy use and should be minimized. 
- No plugs. Eliminate plug loads. The equipment power density significantly increases the loads on the HVAC system. Minimizing power density by selecting energy efficient equipment will not only reduce the costs of running the equipment itself, but it will also greatly lower the HVAC energy costs.

\subsection{Energy Efficient Predesigns}

Initial review of the parametric elimination revealed some areas of focus for further energy analysis.

\subsubsection{Energy Efficient Predesign \#1}

Based on the initial review, we made the following changes to the base case for Energy Efficient Design \#1 (EE \#1):

- Increased the R-values of the walls and roof to $19.0 \mathrm{hr} \cdot \mathrm{ft}^{2} \cdot{ }^{\circ} \mathrm{F} / \mathrm{Btu}$ and $30.0 \mathrm{hr} \cdot \mathrm{ft}^{2} \cdot{ }^{\circ} \mathrm{F} / \mathrm{Btu}$, respectively.

- Added a $62 \%$ effective heat recovery system.

- Modeled night ventilation to try to reduce the peak demand on the building at initial startup.

- Added daylighting controls to a depth of 25 feet and added skylights to the second floor core office space.

Table 2-5 shows the individual effects of adding heat recovery, night ventilation, and daylighting, as well as the combined effects of all the component changes in EE \#1. The heat recovery system decreased heating energy costs by $19 \%$, and such a system would likely pay for itself in a short period of time. Adding night ventilation did not result in a significant net cost reduction because of increases in heating and fan energy costs, but the cooling costs were reduced by $18 \%$. Better control methods should make this a viable alternative, such that heating loads are not increased. Daylighting reduced lighting costs by $63 \%$ and total energy costs by $16 \%$. This area offers the most potential for energy reduction, and the building shape should be reviewed to maximize the daylighting potential.

Table 2-5. Heat Recovery, Night Ventilation, Daylighting, and EE \#1 Energy Cost Analysis for Predesign Dayshift Offices

\begin{tabular}{|c|c|c|c|c|c|c|c|c|c|c|}
\hline & \multicolumn{8}{|c|}{ Energy Operating Costs } & \multirow{2}{*}{$\begin{array}{c}\$ / \\
\mathrm{ft}^{2} \cdot \mathrm{yr}\end{array}$} & \multirow{2}{*}{$\begin{array}{c}\% \\
\text { Difference } \\
\text { from } \\
\text { Base } \\
\text { Case } \\
\end{array}$} \\
\hline & Plug & Lighting & Heating & Cooling & Pump & Fan & DHW & Total & & \\
\hline BASE CASE & 5346 & 6950 & 2238 & 6267 & 1928 & 421 & 115 & 23,265 & 1.54 & - \\
\hline $\begin{array}{l}\text { HEAT } \\
\text { RECOVERY }\end{array}$ & 5346 & 6950 & 1821 & 6267 & 1928 & 421 & 115 & 22,848 & 1.51 & 1.8 \\
\hline $\begin{array}{l}\text { NIGHT } \\
\text { VENTILATION }\end{array}$ & 5346 & 6950 & 2666 & 5151 & 2417 & 421 & 115 & 23,066 & 1.52 & 0.9 \\
\hline DAYLIGHTING & 5346 & 2594 & 3796 & 5469 & 1770 & 421 & 115 & 19,511 & 1.29 & 16.1 \\
\hline EE \#1 & 5346 & 2594 & 1941 & 4723 & 2023 & 421 & 115 & 17,163 & 1.13 & 26.2 \\
\hline
\end{tabular}

As indicated in the parametric elimination, solar gain through the glazing was the next most important cost savings factor after lighting and plug loads because of its effect on the building's cooling loads. The parametric elimination removed solar gains all year long, however, and even though cooling requirements are important, it is also important to maintain some solar gain for passive solar heating as well as to maintain the daylighting levels achieved in EE \#1. For that reason, we analyzed EE \#1 further in an 
attempt to optimize the window area, glazing type, and overhang depth. Generally, daylighting benefits on the north and south exposures allow for more glazing than the east and west exposures where increased cooling loads negate these benefits. Selecting a glass type with a low shading coefficient is important for the east and west exposures; a higher shading coefficient and low U-value are required on the north and south exposures. When overhangs are added to the model with improved glass types and optimized glazing areas, they do lower costs, but not drastically. Based on these simulations, we added the following characteristics to EE \#1 to generate Energy Efficient Design \#2 (EE \#2):

\subsubsection{Energy Efficient Predesign \#2}

- Optimized glazing area

- $\quad 38 \%$ of wall area on north and south exposures (4.5-foot window height)

- $\quad 25 \%$ of wall area on east and west exposures (3.0-foot window height)

- Optimized overhang depth

- $\quad 1.5$ feet

- Optimized glazing type

- $\quad$ South and north exposures: $\mathrm{U}=0.14, \mathrm{SC}=0.55$

- $\quad$ East and west exposures $\mathrm{U}:=0.23, \mathrm{SC}=0.32$.

To demonstrate additional potential, we simulated two more models. Energy Efficient Design \#3 added improved mechanical efficiencies to EE \#2, and Energy Efficient Design \#4 added an improved interior lighting density to EE \#3. These improvements are listed in the sections that follow.

\subsubsection{Energy Efficient Predesign \#3}

- Improved mechanical efficiencies

- $\quad 90 \%$ boiler efficiency

- $\quad 5.5$ COP chiller

- $\quad 75 \%$ efficient heat recovery.

\subsubsection{Energy Efficient Predesign \#4}

- Improved lighting watt density

$$
\text { - } \quad 0.7 \mathrm{~W} / \mathrm{ft}^{2}
$$

Table 2-6 shows the results of these energy efficient designs and their respective savings over the solarneutral base-case model. Figure 2-4 illustrates the lighting and HVAC energy costs of the energy efficient designs compared to the base-case model. Figure 2-5 shows the lighting and HVAC energy cost distribution of the base case, and Figure 2-6 shows the lighting and HVAC energy cost savings of EE \#4 over the base case. The results in Table 2-6 include plug/equipment energy use in differences; the results in Figures 2-4 through 2-6 do not.

Table 2-6. Base-Case Energy Costs Compared with Energy Efficient Predesigns

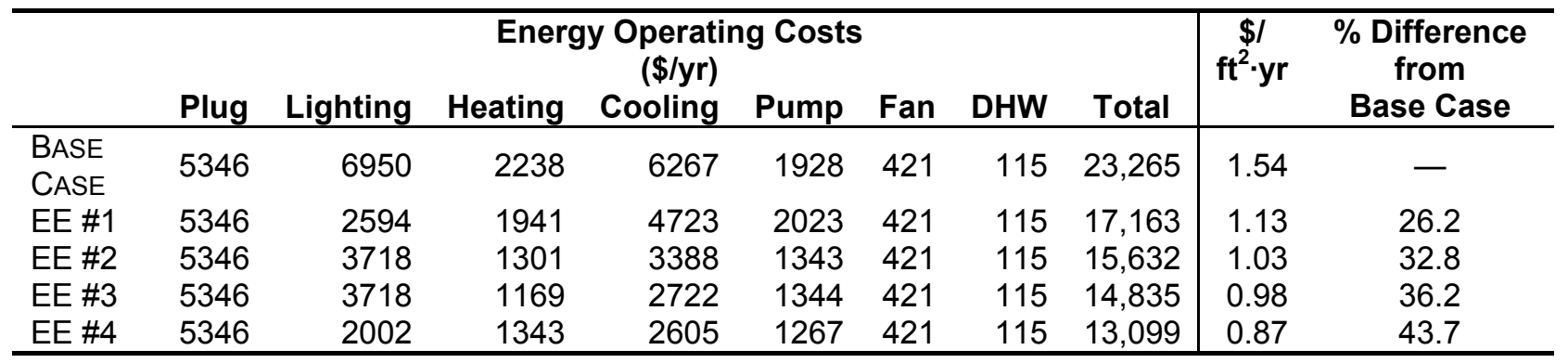




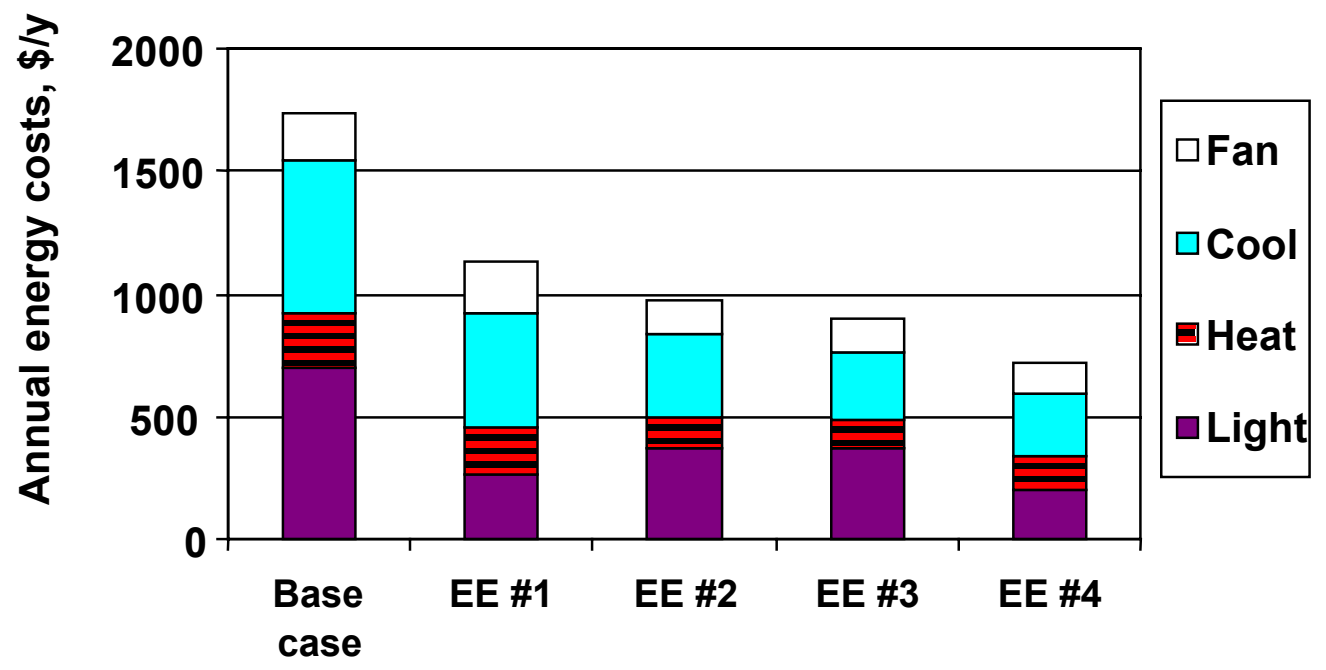

Figure 2-4. Lighting and HVAC energy cost comparison for base-case and energy efficient predesigns

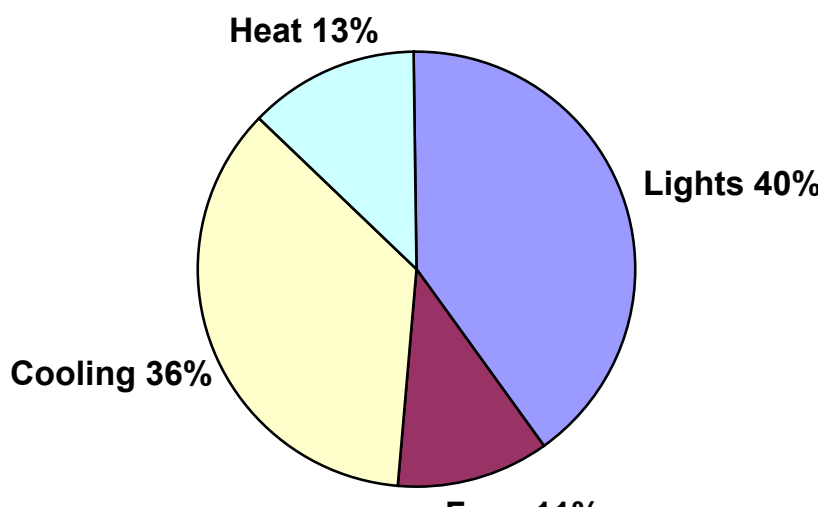

Fans $11 \%$

Figure 2-5. Base-case lighting and HVAC energy costs by category

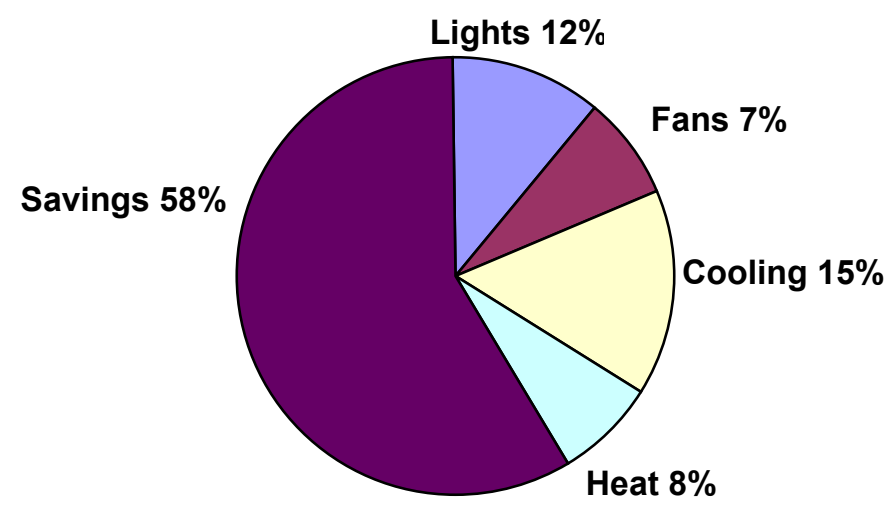

Figure 2-6. EE \#4 lighting and HVAC costs with savings from base case 


\subsection{Predesign Recommendations}

The alternatives simulated in the energy efficient design sufficiently reduced energy use and cost to warrant consideration and implementation in the final building design. These are only estimates based on preliminary program information without focusing on building form. They apply to the day-shift office areas.

- $\quad$ Lighting energy use should be minimized with extensive daylighting and efficient T-8 or better fluorescent lights with occupancy and daylighting controls where appropriate.

- Design occupancy rates determine ventilation air requirements and place significant loads on the heating system. A more detailed review of the building's occupancy schedule and rates should be completed to minimize these requirements. Ventilation air should be controlled with carbon dioxide $\left(\mathrm{CO}_{2}\right)$ sensors. A heat recovery system will significantly reduce the losses that result from the outside air ventilation requirements.

- The windows and the building mass are the main components of the building's passive solar design. Although solar gains during the winter can be stored in the building's mass, conduction losses through fenestration create higher heating loads. In addition, the increased fenestration area has a negative effect during the cooling season. Sizing the south exposure overhangs to shade the windows during the peak summer sun will limit these gains. Selecting double- or triple-paned windows with a low conductivity (U-value) and a high solar heat gain coefficient (SHGC) for the south will maximize gains and decrease conduction losses. Any east and west glass should have a low SHGC and a high visible transmittance, for daylighting. Note that there may be an energy penalty for east and west glazing.

- A reasonable analysis of the expected plug loads should be completed to reduce oversizing the mechanical equipment. Reducing plug loads can have a significant effect on equipment energy costs as well as HVAC initial costs, sizing, and energy costs. ENERGY STAR-rated equipment should be used, and wherever possible, desktop computers should be replaced with laptops and flat screen displays.

- Because mechanical equipment efficiencies have a significant impact on energy costs, decreased equipment size requirements should be used to offset the costs of purchasing higher efficiency units. Equipment choices should be made after the envelope has been established.

This section presented predesign energy analysis performed before a design for the building had been conceived. In the following sections, we present similar analyses, with the key difference that project architects have since proposed a building design. This allows the energy models to be based on an actual design. 


\subsection{Baseline Analysis}

The preceding section presented analysis to support predesign activity. In the rest of the report, we discuss analysis to support design development. For this reason, we repeated the analysis with a new base case, elimination parametrics, and energy efficient design variations. This phase of analysis also models the entire building with garage spaces and office areas on a 24-hour schedule; the analysis in Section 2.0 was for daytime occupancy office areas only.

The Stage One floor plan Scheme "A" with Enclosure Scheme "A-2" was used for base-case analysis conducted with the computer program EnergyPlus, Version 1.0.3 (Crawley 2001). EnergyPlus is a versatile calculation engine capable of modeling loads and annual energy use for entire buildings. The accuracy of EnergyPlus has been validated against other building energy programs using the BESTEST method (Henninger and Witte 2001).

All the simulations reported here are annual, which means that building models run from January 1 through December 31 and use a weather file. The hourly weather file is for Newark, New Jersey, and is based on typical meteorological year, updated format (TMY2) data. Two versions of models were used for base-case analysis - a "Baseline Building Performance Model" and a "Baseline Energy Model." These two models have the same building description and internal loads, but they differ in the HVAC systems used to condition the space. The Baseline Building Performance Model uses the ideal air system model, called Purchased Air in EnergyPlus. The Baseline Energy Model uses HVAC systems specified in proposed informational Appendix (g) for ASHRAE Standard 90.1-2001 (ASHRAE 2001). The proposed Appendix (g) (ASHRAE 2002) offers guidelines for creating a baseline building model to assess a particular building's performance in comparison to a building built to just meet Standard 90.1-2001.

There are several reasons to perform baseline analysis using an ideal HVAC air system (i.e., the Purchased Air model in EnergyPlus) in addition to a specific HVAC system. It is a natural part of the design process to first find solutions for building form, function, and fabric that minimize loads and energy use and then design a suitable HVAC system for the revised building. Using an HVAC system designed for the baseline building may leave the system oversized as a more energy efficient building takes form. A simulation-based analysis exercise should adjust the building form, envelope, and operating characteristics and ascertain the effects in such a manner that the effects of specific changes can be identified. If the HVAC system were to be continually changed, resized, or both, at the same time, elucidating the effects of specific form and fabric measures may be difficult. Practical difficulties also arise when using EnergyPlus because of the complexity of HVAC system models and the time required to create input for them.

Models with detailed HVAC systems may also show significant additional energy use because of nonideal (but perhaps realistic) control situations where cooling and heating components work against each other, as in terminal reheat units. Such energy use could lead to mistakes when interpreting the energy use inherent to the building form and fabric and its sensitivity to climate. Therefore, to better normalize the effect of energy efficiency improvements that are not part of the HVAC system, it is useful to use ideal HVAC air system models for a baseline analysis and a portion of the subsequent comparisons. This model, called Purchased Air in EnergyPlus, provides an essentially unlimited, and perfectly varying, flow of conditioned air at prescribed temperatures $\left(13^{\circ} \mathrm{C}\right.$ for cooling, $50^{\circ} \mathrm{C}$ for heating) and a prescribed humidity ratio (0.015). Because the term Purchased Air is somewhat confusing, we use the expression "ideal HVAC air system" to refer to this EnergyPlus modeling. Such modeling does not provide energy use data that incorporates equipment efficiencies and energy use of ancillary equipment like fans and pumps. An important drawback of using ideal air systems is that economizer cycles and 
return air streams are not modeled. Real HVAC systems may meet the load using economizer cycles and heat recovery systems, thereby requiring much less energy than indicated by the Purchased Air models. (It would be better if ideal models were able to discount cooling needs during periods when free cooling is readily available.) Therefore, building performance baseline modeling is used for only part of the analysis where building fabric (envelope materials, glazing), form (skylights, clerestories, and overhangs) and operation (daylighting and certain ventilation schemes) are varied. Once the building has been optimized, HVAC systems are incorporated back into the models to determine energy use and energy costs relative to the Baseline Energy Model. An ideal HVAC air system is similar to a load calculation, but uses an annual weather file rather than design-day conditions. For this reason, we report peak heating and cooling loads and air mass flow rates to show how maximum equipment loading might vary for designs considered.

Both the performance and energy baseline models are identical except for their HVAC systems. They have eight thermal zones (five office zones and three garage/maintenance zones as listed in Tables 3-1 and 3-2 and illustrated in Figure 3-1). The building envelope specifications, given in Table 3-3, correspond to the minimums provided in Table B-13 in ASHRAE Standard 90.1-2001. Table 3-3 also shows resulting performance levels computed by the EnergyPlus model because these are calculated from complete constructions (and are not given explicitly). Air ventilation requirements are per ASHRAE Standard 62-1999 (ASHRAE 1999) at $10 \mathrm{~L} / \mathrm{s} \cdot$ person for offices (following occupancy schedule) and 7.5 $\mathrm{l} / \mathrm{s} \cdot \mathrm{m}^{2}$ for workshops (on at all times). No skylights are included in these models and no reductions for daylighting are provided. Internal loads from equipment (plug loads) were included, but they are subtracted from the subsequent total energy use when improvements are compared to the baseline. We determined schedules from the architectural program. Figure 3-2 shows selected weekday schedules, and Table 3-4 lists zone air temperature set points for cooling, heating, and setup/setback.

Table 3-1. Thermal Zone Description: Internal Gains

\begin{tabular}{|c|c|c|c|c|c|}
\hline $\begin{array}{l}\text { Zone } \\
\text { Name }\end{array}$ & Usage & $\begin{array}{l}\text { Occupancy } \\
\text { Schedule }\end{array}$ & $\begin{array}{l}\text { Number of } \\
\text { Occupants }\end{array}$ & $\begin{array}{l}\text { Equipment } \\
\text { Loads } \\
\text { (W) }\end{array}$ & $\begin{array}{l}\text { Lighting } \\
\text { Loads } \\
\text { (W) }\end{array}$ \\
\hline$\overline{Z N 1}$ & CUSTOMS, OFFICE & $24 \mathrm{HR}$ & 9 & 1600 & 4160 \\
\hline ZN2 & SHOPS, GARAGE & $24 \mathrm{HR}$ & 7 & 810 & 4050 \\
\hline ZN3 & MAINTENANCE & $24 \mathrm{HR}$ & 10 & 2970 & 14850 \\
\hline & GARAGE & & & & \\
\hline ZN4 & ARFF GARAGE & $24 \mathrm{HR}$ & 10 & 600 & 3000 \\
\hline ZN5 & OFFICE & 7 A.M.-10 P.M & 20 & 6500 & 8450 \\
\hline ZN6 & OFFICE & 7 A.M -10 & 15 & 3200 & 4160 \\
\hline ZN7 & OfFICE & $\begin{array}{l}\text { P.M. } \\
7 \text { A.M -10 }\end{array}$ & 20 & 6500 & 8450 \\
\hline ZN8 & OFFICE & $\begin{array}{l}\text { P.M. } \\
24 \text { HR }\end{array}$ & 15 & 3200 & 4160 \\
\hline
\end{tabular}

Table 3-2. Thermal Zone Description: Geometry

\begin{tabular}{lccccc}
\hline $\begin{array}{c}\text { Zone } \\
\text { Name }\end{array}$ & $\begin{array}{c}\text { Floor Area } \\
\left(\mathbf{m}^{2}\right)\end{array}$ & $\begin{array}{c}\text { Ceiling } \\
\text { Height } \\
(\mathbf{m})\end{array}$ & $\begin{array}{c}\text { Glazed } \\
\text { Area } \\
\left(\mathbf{m}^{2}\right)\end{array}$ & \% Glazed & $\begin{array}{c}\text { Design } \\
\text { Ventilation } \\
\left(\mathbf{m}^{3} / \mathbf{s}\right)\end{array}$ \\
\hline ZN1 & 297 & 3.962 & 142.8 & 61 & 0.09 \\
ZN2 & 251 & 6.248 & 15.4 & 8 & 1.88 \\
ZN3 & 920 & 7.467 & 94.8 & 18 & 6.90
\end{tabular}




\begin{tabular}{llllll} 
ZN4 & 186 & 8.839 & 36.4 & 24 & 1.39 \\
ZN5 & 604 & 4.267 & 101.7 & 43 & 0.20 \\
ZN6 & 297 & 4.267 & 82.1 & 53 & 0.15 \\
ZN7 & 597 & 4.572 & 111.8 & 41 & 0.20 \\
ZN8 & 297 & 4.572 & 115.1 & 70 & 0.15 \\
\hline
\end{tabular}

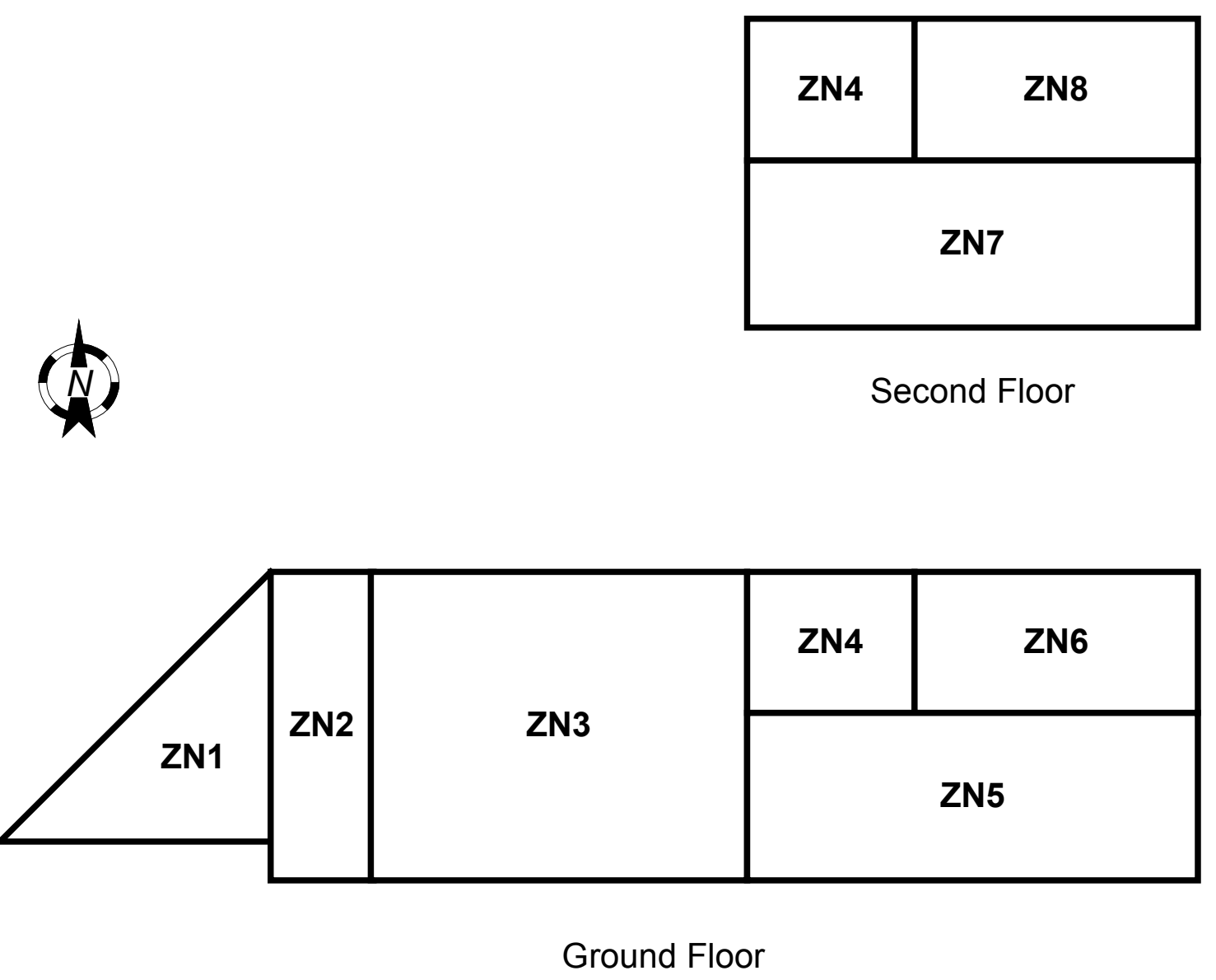

Figure 3-1. Thermal zones used in design development models

Table 3-3. Envelope Specifications for Baseline Models per ASHRAE 90.1-2001

\begin{tabular}{lll}
\hline \multicolumn{1}{c}{ Envelope Component } & \multicolumn{1}{c}{$\begin{array}{l}\mathbf{9 0 . 1} \text { Minimum } \\
\text { Requirements }\end{array}$} & $\begin{array}{r}\text { EnergyPlus } \\
\text { As-Modeled }\end{array}$ \\
\hline EXTERIOR WALLS $\left(\mathrm{M}^{2} \cdot \mathrm{K}\right) / \mathrm{W}$ & $\mathrm{R}_{\mathrm{SI}}-2.3$ & $\mathrm{R}_{\mathrm{SI}}-2.73$ \\
BUILT-UP ROOF $\left(\mathrm{M}^{2} \cdot \mathrm{K}\right) / \mathrm{W}$ & $\mathrm{R}_{\mathrm{SI}}-2.6$ & $\mathrm{R}_{\mathrm{SI}}-2.70$ \\
NORTH-FACING WINDOWS & $\mathrm{U}_{\mathrm{SI}}-3.24$ & $\mathrm{U}_{\mathrm{SI}}-3.14$ \\
W/(M $\left(\mathrm{M}^{2} \cdot \mathrm{K}\right)$ & $\mathrm{SHGC}-0.49$ & $\mathrm{SHGC}-0.488$ \\
OTHER-FACING WINDOWS & $\mathrm{U}_{\mathrm{SI}}-3.24$ & $\mathrm{U}_{\mathrm{SI}}-3.14$ \\
W/(M $\left.\mathrm{M}^{2} \cdot \mathrm{K}\right)$ & $\mathrm{SHGC}-0.39$ & $\mathrm{SHGC}-0.397$ \\
\hline
\end{tabular}




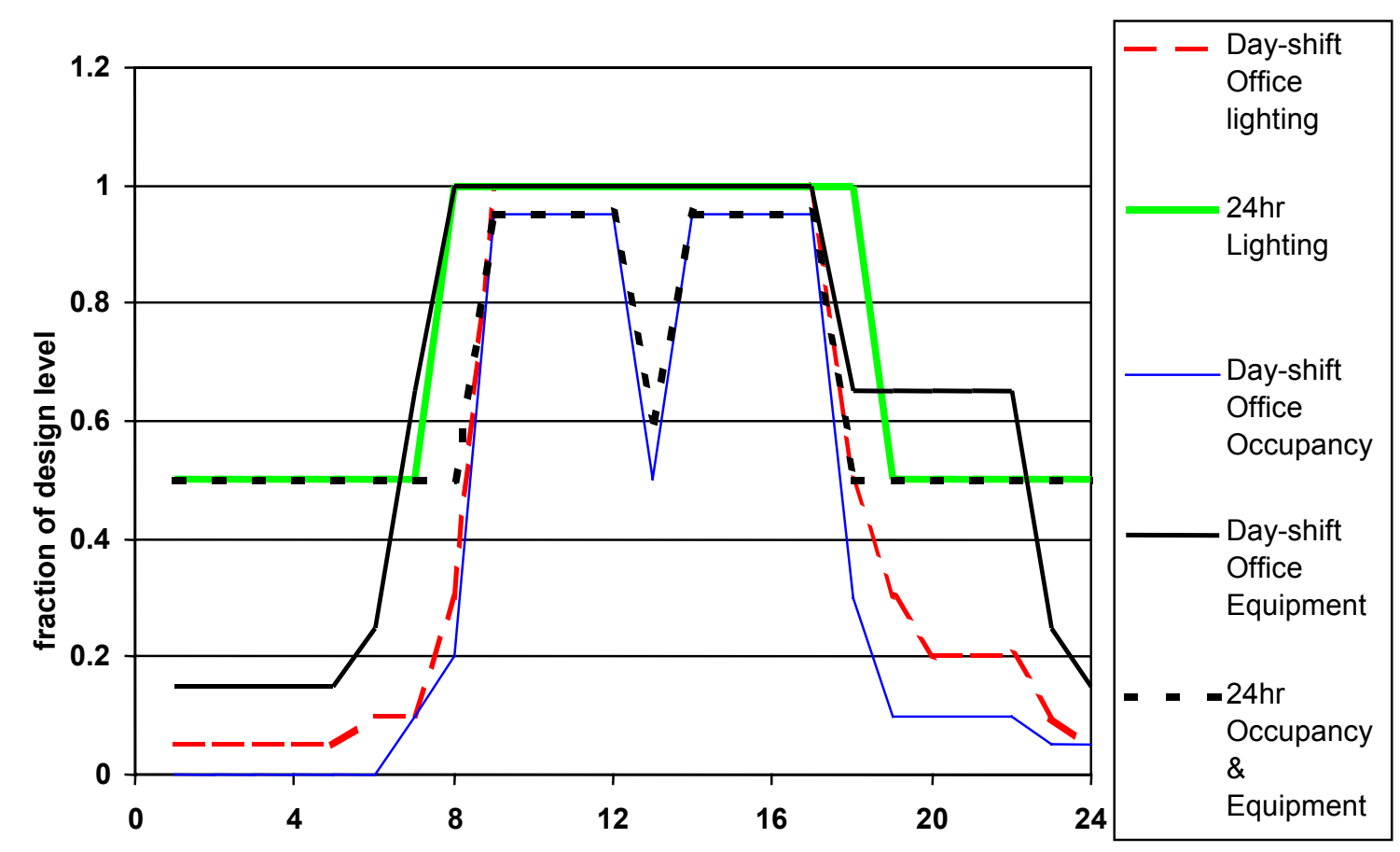

Hour of day

Figure 3-2. Weekday schedules for occupancy, lighting, and equipment

Table 3-4. Zone Air Temperature Set Points

\begin{tabular}{lcccc}
\hline Zone Name & $\begin{array}{c}\text { Heating Set } \\
\text { Point } \\
\left({ }^{\circ} \mathrm{C}\right)\end{array}$ & $\begin{array}{c}\text { Heating } \\
\text { Setback } \\
\left({ }^{\circ} \mathrm{C}\right)\end{array}$ & $\begin{array}{c}\text { Cooling Set } \\
\text { Point } \\
\left({ }^{\circ} \mathrm{C}\right)\end{array}$ & $\begin{array}{c}\text { Cooling Setup } \\
\left({ }^{\circ} \mathrm{C}\right)\end{array}$ \\
\hline ZN1 & 21.0 & $\mathrm{~N} / \mathrm{A}$ & 24.0 & $\mathrm{~N} / \mathrm{A}$ \\
ZN2 & 10.0 & $\mathrm{~N} / \mathrm{A}$ & 24.0 & $\mathrm{~N} / \mathrm{A}$ \\
ZN3 & 10.0 & $\mathrm{~N} / \mathrm{A}$ & 24.0 & $\mathrm{~N} / \mathrm{A}$ \\
ZN4 & 10.0 & $\mathrm{~N} / \mathrm{A}$ & 24.0 & $\mathrm{~N} / \mathrm{A}$ \\
ZN5 & 21.0 & 17.0 & 24.0 & 30.0 \\
ZN6 & 21.0 & 17.0 & 24.0 & 30.0 \\
ZN7 & 21.0 & 17.0 & 24.0 & 30.0 \\
ZN8 & 21.0 & $\mathrm{~N} / \mathrm{A}$ & 24.0 & $\mathrm{~N} / \mathrm{A}$ \\
\hline
\end{tabular}

The building has two distinctly different activity areas, office and garage. Because these two areas have very different ventilation and thermal conditioning requirements, it follows that building analysis should be separated into two groups. The Office group of zones in this report includes ZN1, ZN5, ZN6, ZN7, and ZN8. The Garage group of zones in this report includes ZN2, ZN3, and ZN4.

\subsection{Baseline Building Performance Model}

We used the Baseline Building Performance Model a reference for understanding improvements to the building's features that are not directly related to HVAC systems. The spaces are conditioned using an ideal HVAC air system. The proposed Addendum (e) to ASHRAE 90.1-2001 discusses situations where the baseline building should be rotated through the four cardinal directions and results averaged to obtain a baseline performance. Lighting, plug loads, and fan power did not change in this modeling. However, heating and cooling energy use is affected by how the building is exposed to the sun. Table 3-5 gives the 
results for the Baseline Building Performance Model. For actual energy use and costs, see Sections 3.2 and 3.3, respectively.

Table 3-5. Baseline Building Performance Model Results for Energy Use

\begin{tabular}{|c|c|c|c|c|c|c|c|}
\hline $\begin{array}{l}\text { Zone } \\
\text { Group }\end{array}$ & $\begin{array}{l}\text { Rotation } \\
\text { (degree) }\end{array}$ & $\begin{array}{l}\text { Lights } \\
\text { (MWh/yr) }\end{array}$ & $\begin{array}{c}\text { Equipment } \\
\text { (MWh/yr) }\end{array}$ & $\begin{array}{l}\text { Cooling } \\
\text { (MWh/yr) }\end{array}$ & $\begin{array}{l}\text { Heating } \\
\text { (MWh/yr) }\end{array}$ & $\begin{array}{l}\text { Total w/o } \\
\text { Equipment } \\
\text { (MWh/yr) }\end{array}$ & $\begin{array}{c}\text { Intensity } \\
\text { (kWh/ } \\
\left.\mathrm{m}^{2} \cdot \mathrm{yr}\right)\end{array}$ \\
\hline \multirow{5}{*}{ GARAGES } & 0 & 133.5 & 24.2 & 0.0 & 318.6 & 452.1 & 333.1 \\
\hline & 90 & 133.5 & 24.2 & 0.0 & 314.9 & 448.4 & 330.4 \\
\hline & 180 & 133.5 & 24.2 & 0.0 & 305.0 & 438.5 & 323.1 \\
\hline & 270 & 133.5 & 24.2 & 0.0 & 315.2 & 448.7 & 330.7 \\
\hline & AVERAGE & 133.5 & 24.2 & 0.0 & 313.4 & 446.9 & 329.4 \\
\hline \multirow{5}{*}{ OFFICES } & 0 & 117.5 & 95.1 & 163.5 & 38.7 & 319.7 & 152.3 \\
\hline & 90 & 117.5 & 95.1 & 178.1 & 38.0 & 333.6 & 158.9 \\
\hline & 180 & 117.5 & 95.1 & 169.3 & 37.8 & 324.6 & 154.6 \\
\hline & 270 & 117.5 & 95.1 & 169.0 & 40.7 & 327.2 & 155.9 \\
\hline & AVERAGE & 117.5 & 95.1 & 170.0 & 38.8 & 326.2 & 155.4 \\
\hline
\end{tabular}

The ideal HVAC air system also serves as an alternate method of sizing HVAC air systems. (The other method is to use automatic sizing models in energy programs like DOE-2.1E and EnergyPlus.) The drawback of using results from an ideal HVAC air system to size air handlers is that different capacities may be needed to overcome poor controlling and reheat situations in a real system. In addition, designday conditions are probably more severe. However, EnergyPlus routines for automatically sizing HVAC systems can be problematic, leading to the desirability of using the quite robust models for the ideal Purchased Air systems to check sizing. Table 3-6 gives the loads that the air system must meet, by zone, for the unrotated baseline building performance model.

Table 3-6. Baseline Building Performance Model Results for Peak Loads

\begin{tabular}{llll}
\hline Zone Name & $\begin{array}{c}\text { Peak heating } \\
\text { Load } \\
\text { (W) }\end{array}$ & $\begin{array}{c}\text { Peak Cooling } \\
\text { Load } \\
\text { (W) }\end{array}$ & $\begin{array}{c}\text { Peak Air Mass } \\
\text { Flow } \\
\text { (kg/s) }\end{array}$ \\
\hline ZN2 & 65,100 & 0 & 1.6 \\
ZN3 & 241,000 & 0 & 5.92 \\
ZN4 & 49,000 & 0 & 1.21 \\
\hline GARAGES & 355,000 & 0 & 8.73 \\
COINCIDENT & & & \\
& 15,400 & 26,200 & 2.33 \\
ZN1 & 16,100 & 30,400 & 2.70 \\
ZN5 & 12,100 & 16,000 & 1.42 \\
ZN6 & 25,000 & 35,500 & 3.15 \\
ZN7 & 14,000 & 20,900 & 1.85 \\
ZN8 & 73,100 & 121,000 & 10.7 \\
\hline OFFICES & & & \\
COINCIDENT & & &
\end{tabular}

\subsection{Baseline Energy Model}

For the Baseline Energy Model, each office zone has its own packaged direct expansion (DX) cooling systems with outside air economizers. The COP is 3.2 for the smaller units and 3.1 for the larger ones. The garage and maintenance zones have similar systems but without cooling coils. These systems have 
outdoor air mixers for supplying required ventilation air and implementing free cooling using an air-side economizer. Gas-fired heating coils provide heat for all the zones.

Table 3-7 summarizes the results from rotating the Baseline Energy Model, where results have been combined separately for garage zones and office zones.

Table 3-7. Baseline Energy Model Results for Energy Use

\begin{tabular}{|c|c|c|c|c|c|c|c|c|}
\hline & $\begin{array}{l}\text { Rotation } \\
\text { (degree) }\end{array}$ & $\begin{array}{l}\text { Lights } \\
\text { (MWh/yr) }\end{array}$ & $\begin{array}{c}\text { Equipment } \\
\text { (MWh/yr) }\end{array}$ & $\begin{array}{c}\text { Fans } \\
\text { (MWh/yr) }\end{array}$ & $\begin{array}{c}\text { Cooling } \\
\text { (MWh/yr) }\end{array}$ & $\begin{array}{l}\text { Heating } \\
\text { (MWh/yr) }\end{array}$ & $\begin{array}{l}\text { Total w/o } \\
\text { Equipment } \\
\text { (MWh/y)) }\end{array}$ & $\begin{array}{c}\text { Intensity } \\
(\mathrm{kWh} / \\
\left.\mathrm{m}^{2} \cdot \mathrm{yr}\right)\end{array}$ \\
\hline \multirow{5}{*}{ Garages } & 0 & 133.5 & 24.2 & 78.8 & 0 & 326.6 & 538.9 & 397.1 \\
\hline & 90 & 133.5 & 24.2 & 78.8 & 0 & 322.4 & 534.7 & 394.1 \\
\hline & 180 & 133.5 & 24.2 & 78.8 & 0 & 310.3 & 522.6 & 385.1 \\
\hline & 270 & 133.5 & 24.2 & 78.8 & 0 & 322.6 & 534.9 & 394.2 \\
\hline & AVERAGE & 133.5 & 24.2 & 78.8 & 0 & 320.5 & 532.8 & 392.6 \\
\hline \multirow{5}{*}{ Offices } & 0 & 117.5 & 95.1 & 61.0 & 49.2 & 85.5 & 313.2 & 149.2 \\
\hline & 90 & 117.5 & 95.1 & 61.0 & 52.4 & 84.8 & 315.7 & 150.4 \\
\hline & 180 & 117.5 & 95.1 & 61.0 & 50.4 & 86.3 & 315.2 & 150.2 \\
\hline & 270 & 117.5 & 95.1 & 61.0 & 51.8 & 89.7 & 320.1 & 152.5 \\
\hline & AVERAGE & 117.5 & 95.1 & 61.0 & 51.0 & 86.6 & 316.1 & 150.6 \\
\hline
\end{tabular}

The rotation study shows that simply rotating the building 180 degrees reduces heating energy in garage zones by $5 \%$ because there are more windows on the north side of the building. Going through the process of rotating and averaging results resulted in only a slight change $(0.4 \%)$ to the Baseline Energy Model results (with plug loads removed). The unrotated energy usage for the entire building is 852.1 $\mathrm{MWh} / \mathrm{yr}$. After averaging four rotations, this changed to $848.9 \mathrm{MWh} / \mathrm{yr}$.

\subsection{Baseline Energy Costs}

Although levels of energy usage are important metrics, energy cost is another useful metric that can be used to compare dissimilar types of energy. Energy cost can also be factored into important economic analysis. Appendix D summarizes how we used simulation results from EnergyPlus to compute cost data for this analysis. We had to compute these data using an ancillary program because EnergyPlus does not offer the economic analysis. Table 3-8 lists the results for energy cost from the Baseline Energy Model. Total energy cost (with plug loads removed) for the entire baseline building per ASHRAE 90.1-2001(g), averaged for the four rotations, is $\$ 86,545 / \mathrm{yr}$ or $\$ 25.0 / \mathrm{m}^{2} \cdot \mathrm{yr}\left(\$ 2.32 / \mathrm{ft}^{2} \cdot \mathrm{yr}\right)$. 
Table 3-8. Baseline Energy Model Results for Energy Costs

\begin{tabular}{|c|c|c|c|c|c|c|c|c|}
\hline & $\begin{array}{l}\text { Rotation } \\
\text { (degree) }\end{array}$ & $\begin{array}{c}\text { Lights } \\
\text { (\$/yr) }\end{array}$ & $\begin{array}{l}\text { Equipment } \\
\text { (\$/yr) }\end{array}$ & $\begin{array}{l}\text { Fans } \\
\text { (\$/yr) }\end{array}$ & $\begin{array}{c}\text { Cooling } \\
\text { (\$/yr) }\end{array}$ & $\begin{array}{c}\text { Heating } \\
\text { (\$/yr) }\end{array}$ & $\begin{array}{c}\text { Total w/o } \\
\text { Equipment } \\
\text { (\$/yr) }\end{array}$ & $\begin{array}{l}\text { Intensity } \\
\left(\$ / \mathrm{m}^{2} \cdot \mathrm{yr}\right)\end{array}$ \\
\hline \multirow{5}{*}{ Garages } & 0 & 22,260 & 4,032 & 13,030 & 0 & 10,040 & 45,330 & 33.40 \\
\hline & 90 & 22,260 & 4,032 & 13,030 & 0 & 9,914 & 45,204 & 33.31 \\
\hline & 180 & 22,260 & 4,032 & 13,030 & 0 & 9,544 & 44,834 & 33.04 \\
\hline & 270 & 22,260 & 4,032 & 13,030 & 0 & 9,920 & 45,210 & 33.32 \\
\hline & AVERAGE & 22,260 & 4,032 & 13,030 & 0 & 9,854 & 45,144 & 33.27 \\
\hline \multirow{5}{*}{ Offices } & 0 & 19,770 & 15,930 & 10,060 & 8,598 & 2,629 & 41,057 & 19.56 \\
\hline & 90 & 19,770 & 15,930 & 10,060 & 9,162 & 2,609 & 41,601 & 19.82 \\
\hline & 180 & 19,770 & 15,930 & 10,060 & 8,813 & 2,654 & 41,297 & 19.67 \\
\hline & 270 & 19,770 & 15,930 & 10,060 & 9,059 & 2,760 & 41,649 & 19.84 \\
\hline & AVERAGE & 19,770 & 15,930 & 10,060 & 8,908 & 2,663 & 41,401 & 19.72 \\
\hline
\end{tabular}

\subsection{Baseline Thermal Comfort}

Occupant thermal comfort is the main goal of conditioning the interior spaces of buildings, making it useful to compare comfort as well as energy use and cost. Historically, energy analysis studies of design implications have focused on energy use and cost and have not necessarily quantified how energy efficient designs affect occupant thermal comfort. This can be justifiable in situations where space loads are being completely met by HVAC equipment because little difference in air temperatures would be expected. However, because the maintenance and garage spaces in this project are not cooled, there is a danger of designing a building for reduced heating energy and costs that subsequently overheats in the summer. Because no energy is used for cooling, energy analysis would not capture any strategies that help or hinder occupant comfort in these spaces during the summer.

EnergyPlus yields results for several methods of predicting occupant thermal comfort. For this analysis, we selected the Fanger (1982) model for predicted mean vote (PMV) as implemented in EnergyPlus. PMV is in units of the ASHRAE Thermal Sensation Scale where +3 represents a "hot" sensation, +2 represents "warm," +1 is "slightly warm," 0 is "neutral," -1 is "slightly cool," -2 is "cool," and -3 is "cold." Hourly data for PMV are reduced to facilitate comparisons between different building models by summing the number of hours that PMV values are above or below certain thresholds. Table 3-9 presents results for the predictions of how occupants will sense garage spaces during the cooling season from the unrotated Baseline Building Performance Model.

Table 3-9. Summary of Baseline Performance Model Predictions for Occupant Thermal Comfort on ASHRAE Thermal Sensation Scale for Uncooled Garages and Shops

\begin{tabular}{|c|c|c|c|}
\hline Zone Name & $\begin{array}{l}\text { Hours per Year } \\
\text { Above }+1.5\end{array}$ & $\begin{array}{c}\text { Hours per Year } \\
\text { Above }+2.0\end{array}$ & $\begin{array}{l}\text { Hours per Year } \\
\text { Above }+2.5\end{array}$ \\
\hline ZN2 & 445 & 75 & 9 \\
\hline ZN3 & 489 & 89 & 17 \\
\hline ZN4 & 550 & 121 & 20 \\
\hline
\end{tabular}

More subtle reasons to quantify occupant thermal comfort arise because of arguments made in support of using building envelope components with high levels of thermal performance. Energy use and cost may not justify the highest levels of envelope thermal performance in commercial buildings where energy use characteristics are dominated by ventilation and internal loads. Therefore, comfort considerations are sometimes used to justify high-performance envelopes based on the economic benefits of worker 
productivity and increased usability of perimeter floor space. During the winter, inside surface temperatures are warmer for envelope components with higher thermal performance. This leads to improved comfort because occupants exchange thermal radiation with envelope surfaces regardless of the air temperature. Comfort models capture this effect by incorporating radiant temperatures. (Other issues surrounding the inside surface temperatures, such as natural-convection-induced drafts and condensation, are not as easily considered.) In preparation for arguing that comfort issues warrant high-performance envelope materials, we reduced the hourly PMV results for the 24-hour office zones. Table 3-10 gives these results for the Baseline Building Performance Model.

Table 3-10. Summary of Baseline Building Performance Model Predictions for Occupant Thermal Comfort on ASHRAE Thermal Sensation Scale for Heating in 24-Hour Offices

\begin{tabular}{llccc}
\hline Zone Name & $\begin{array}{c}\text { Hours per Year } \\
\text { Below } \\
-\mathbf{0 . 4}\end{array}$ & $\begin{array}{c}\text { Hours per Year } \\
\text { Below } \\
-\mathbf{0 . 3}\end{array}$ & $\begin{array}{c}\text { Hours per Year } \\
\text { Below } \\
-\mathbf{0 . 2}\end{array}$ \\
\hline ZN1 & 11 & 372 & 2051 & \\
ZN8 & 2 & 575 & 2614 & \\
\hline
\end{tabular}

The Baseline Energy Model may lead to different comfort conditions than those obtained with the Baseline Building Performance Model because HVAC system models and controls differ. Therefore, we also reduced comfort results for these models to arrive at a comfort baseline, which is given in Table 311. The garage zones are much less comfortable than the office zones because the heating set point is low and they are not actively cooled.

Table 3-11. Summary of Baseline Energy Model Predictions for Occupant Thermal Comfort on ASHRAE Thermal Sensation Scale for 24-Hour Office and Garage

\begin{tabular}{ccccccc}
\hline $\begin{array}{c}\text { Zone } \\
\text { Name }\end{array}$ & $\begin{array}{c}\text { Hours per } \\
\text { Year } \\
\text { Below }\end{array}$ & $\begin{array}{c}\text { Hours per } \\
\text { Year } \\
\text { Below }\end{array}$ & $\begin{array}{c}\text { Hours per } \\
\text { Year } \\
\text { Below }\end{array}$ & $\begin{array}{c}\text { Hours per } \\
\text { Year } \\
\text { Above }\end{array}$ & $\begin{array}{c}\text { Hours per } \\
\text { Year } \\
\text { Above }\end{array}$ & $\begin{array}{c}\text { Hours per } \\
\text { Year } \\
\text { Above }\end{array}$ \\
& $\mathbf{- 2 . 0}$ & $\mathbf{- 1 . 0}$ & $-\mathbf{0 . 5}$ & $\mathbf{+ 0 . 5}$ & $\mathbf{+ 1 . 0}$ & $\mathbf{+ 2 . 0}$ \\
\hline ZN1 & 0 & 0 & 1332 & 3584 & 293 & 0 \\
ZN3 & 3202 & 4639 & 5132 & 2229 & 1399 & 145 \\
\hline
\end{tabular}




\subsection{Elimination Parametric Study}

Using a customary approach where various factors are zeroed/negated in isolation, we performed a parametric analysis. This analysis differs from the one presented in Section 2.2 in that this analysis used the Baseline Energy Model, which corresponds to the Stage One proposed building rather than to a generic solar-neutral office building. Because of the significant differences between the office-type and garage-type zones, we split the study presented in this section into two groups with separate baseline performance levels for each. Table 4-1 summarizes how the different measures would rate compared to the ASHRAE 90.1-2001(e) baseline (where plug loads are removed).

Table 4-1. Summary of Baseline Parametric Study by Type of Zone

\begin{tabular}{lll}
\hline \multicolumn{1}{c}{ Case } & $\begin{array}{c}\text { Garage Zones } \\
\% \text { Change }\end{array}$ & $\begin{array}{c}\text { Office Zones } \\
\% \text { change }\end{array}$ \\
\hline R-100 WALLS & -1.2 & -2.2 \\
R-100 ROOF & -2.5 & -6.3 \\
R-100 FLOOR & +3.3 & +0.8 \\
U-0.01 GLAZING & -0.7 & -6.7 \\
ALL R-100/U-0.01 & -1.2 & -13.1 \\
NO SOLAR GLAZING & +0.46 & +1.9 \\
NO LIGHTS & -14.5 & -31.3 \\
NO PEOPLE & +1.4 & +1.0 \\
NO EQUIPMENT & +1.9 & +3.7 \\
NO OS AIR & -60.6 & -11.9 \\
NO INFILTRATION & -0.03 & -4.5 \\
\hline
\end{tabular}

The results show that envelope improvements offer only minor improvements in energy efficiency and that lighting and outdoor air ventilation are important. See Appendix F for additional results of a parametric elimination study where results for the entire building are presented together and compared to earlier simulations using the DOE-2.1E computer program. 


\subsection{Improved Energy Designs}

In this section, we present energy simulation results for improvements to the baseline building. The starting point is the proposed Stage One, Scheme A-2 building plan built to meet ASHRAE 90.1-2001 and modeled according to proposed informational Appendix (g). The baseline modeling (see Section 3.0) yields metrics for evaluating if the goal of reducing energy costs by $50 \%$ has been met. The elimination modeling (see Section 4.0) furnishes guidance on where to place focus when developing energy efficient designs. Quantitative predictions for how design measures will affect energy use are made possible through the extensive use of energy simulation. Although we recognize that whole-building analysis achieves the best results, it is useful to proceed in a step-by-step manner to organize documentation and gain insight into complex integration issues. This section presents the development of an improved energy efficient design (and EnergyPlus models and results) in the following stages and subsections:

1. Envelope Improvements-Section 5.1

2. Daylighting with Skylights-Section 5.2

3. Daylighting with Clerestories and Overhangs-Section 5.3

4. Demand-Controlled Ventilation-Section 5.4

5. HVAC systems-Section 5.5.

See Section 7.0 for a discussion of the results and Section 8.0 for design recommendations based on those results.

In general, such a study should also investigate modifications of the overall shape and layout, or "massing," of the building. However, no major reconfigurations of the floor plan were made for this building because it had already been elongated and given an advantageous east-west orientation (perhaps in response to predesign analysis). In addition, extensive efforts to do additional massing studies are not warranted at this time because the Teterboro Airport Building is currently on hold and its architectural program is expected to change.

\subsection{Envelope Constructions}

Increasing levels of thermal insulation and using glazing with improved thermal and optical properties are often the first and relatively simple methods used to improve the energy efficiency of a building. However, the relatively high levels of envelope thermal performance specified in ASHRAE 90.1-2001 make this measure less effective than when less stringent standards are followed. The elimination parametric study shows that even outrageous levels of thermal performance would have relatively minor effects on overall energy use. Nevertheless, the highest performance buildings will tend to use envelope components with levels of thermal performance that exceed code.

Wall and roof construction assemblies recommended by the architect appear adequate and were used in the "Improved Envelope Model." This exterior wall construction includes a metal panel rain screen, rigid foam insulation, cellulose cavity insulation, and gypsum wallboard. We selected glazing for the modeling based on Viracon's Azurlite ${ }^{\mathrm{TM}}$, but with a low-emittance coating in argon-filled, insulating glazing units. We modeled a second version of envelope modifications called "High-Mass Envelope" with tiled floors and slabs instead of carpet and exterior walls with concrete block adjacent to interior wall board and insulation on the outside. The interior walls were symmetric, composed of double layers of concrete block walls with a layer of foam insulation between them. Table 5-1 gives the performance levels of envelope components (as computed by EnergyPlus). 
The floor slab was not insulated underneath because model results showed that ground contact is beneficial. Vertical insulation should be installed around the perimeter of the slab as required in ASHRAE 90.1-2001. Note that ground temperature calculations were based on the presence of such insulation, but the whole building models do not account for vertical perimeter slab insulation. These results depend on the ground temperatures modeled by the preprocessor (slab.exe, provided with EnergyPlus) where temperatures were found to stay around $20^{\circ} \mathrm{C}$.

Table 5-1. Envelope Thermal Performance Levels

\begin{tabular}{llll}
\hline \multicolumn{1}{c}{ Item } & $\begin{array}{c}\text { Baseline } \\
\text { Model }\end{array}$ & $\begin{array}{c}\text { Improved } \\
\text { Envelope } \\
\text { Model }\end{array}$ & $\begin{array}{c}\text { High-Mass } \\
\text { Envelope }\end{array}$ \\
\hline EXTERIOR WALL CONDUCTANCE $\left(\mathrm{W} / \mathrm{M}^{2} \cdot \mathrm{K}\right)$ & 0.3664 & 0.2881 & 0.4067 \\
INTERIOR WALL CONDUCTANCE $\left(\mathrm{W} / \mathrm{M}^{2} \cdot \mathrm{K}\right)$ & 0.4088 & 0.4088 & 0.5064 \\
ROOF CONDUCTANCE $\left(\mathrm{W} / \mathrm{M}^{2} \cdot \mathrm{K}\right)$ & 0.3701 & 0.1939 & 0.1939 \\
SLAB + 0.3 M DIRT CONDUCTANCE & 0.5217 & 0.5217 & 0.5217 \\
$\left(\mathrm{~W} / \mathrm{M}^{2} \cdot \mathrm{K}\right)$ & & & 0.5191 \\
CARPETED SLAB + 0.3 M DIRT & 0.4687 & 0.4687 & $(\mathrm{TILED})$ \\
CONDUCTANCE $\left(\mathrm{W} / \mathrm{M}^{2} \cdot \mathrm{K}\right)$ & & & 0.3252 \\
INTERIOR FLOOR CONDUCTANCE $\left(\mathrm{W} / \mathrm{M}^{2} \cdot \mathrm{K}\right)$ & 0.6599 & 0.3046 & $($ TILED) \\
NORTH GLAZING CONDUCTANCE $\left(\mathrm{W} / \mathrm{M}^{2} \cdot \mathrm{K}\right)$ & 3.139 & 1.479 & 1.479 \\
NORTH GLAZING SHGC & 0.488 & 0.175 & 0.175 \\
NON-NORTH GLAZING CONDUCTANCE & 3.138 & 1.479 & 1.479 \\
(W/M 'K) & 0.397 & 0.175 & 0.175 \\
NON-NORTH GLAZING SHGC & & & \\
\hline
\end{tabular}

Table 5-2 summarizes results for energy use and peak load conditions, and Tables 5-3 and 5-4 give the occupant thermal comfort results.

Table 5-2. Summary of Results for Energy Use and Peak Loads: Envelope Change Models

\begin{tabular}{|c|c|c|c|c|c|c|}
\hline & \multicolumn{3}{|c|}{ Garages } & \multicolumn{3}{|c|}{ Offices } \\
\hline & $\begin{array}{c}\text { Baseline Rot. } 0 \\
\text { (unrotated) }\end{array}$ & $\begin{array}{l}\text { Improved } \\
\text { Envelope }\end{array}$ & $\begin{array}{l}\text { High- } \\
\text { Mass }\end{array}$ & Baseline & $\begin{array}{l}\text { Improved } \\
\text { Envelope }\end{array}$ & $\begin{array}{l}\text { High- } \\
\text { Mass }\end{array}$ \\
\hline $\begin{array}{l}\text { IDEAL HEATING } \\
\text { ENERGY (MWH/YR) }\end{array}$ & 318.6 & $\begin{array}{l}309.7 \\
(-2.8 \%)\end{array}$ & $\begin{array}{l}307.6 \\
(-3.5 \%)\end{array}$ & 38.7 & $\begin{array}{l}9.8 \\
(-74.7 \%)\end{array}$ & $\begin{array}{l}8.4 \\
(-78.3 \%)\end{array}$ \\
\hline $\begin{array}{l}\text { IDEAL COOLING } \\
\text { ENERGY }(\mathrm{MWH} / \mathrm{YR})\end{array}$ & 0 & 0.0 & 0.0 & 163.5 & $\begin{array}{l}140.0 \\
(-14.4 \%)\end{array}$ & $\begin{array}{l}131.6 \\
(-19.5 \%)\end{array}$ \\
\hline $\begin{array}{l}\text { PEAK HEATING LOAD } \\
\text { (W) }\end{array}$ & 355,000 & $\begin{array}{l}345,000 \\
(-2.8 \%)\end{array}$ & $\begin{array}{l}343,000 \\
(-3.4 \%)\end{array}$ & 73,100 & $\begin{array}{l}39,300 \\
(-46.2 \%)\end{array}$ & $\begin{array}{l}46,100 \\
(-36.9 \%)\end{array}$ \\
\hline $\begin{array}{l}\text { PEAK COOLING LOAD } \\
\text { (W) } \\
\text { PEAK AIR MASS }\end{array}$ & 0.0 & 0.0 & 0.0 & 121,00 & $\begin{array}{l}89,100 \\
(-26.4 \%)\end{array}$ & $\begin{array}{l}84,300 \\
(-30.3 \%)\end{array}$ \\
\hline $\begin{array}{l}\text { FLOW RATE } \\
\text { (KG/S) }\end{array}$ & 8.73 & 8.50 & 8.43 & 10.7 & 7.91 & 7.49 \\
\hline
\end{tabular}


Table 5-3. Summary of Occupant Thermal Comfort Predictions on ASHRAE Thermal Sensation Scale for Uncooled Garages and Shops: Envelope Change Models

\begin{tabular}{|c|c|c|c|c|}
\hline $\begin{array}{l}\text { Zone } \\
\text { Name }\end{array}$ & Scenario & $\begin{array}{c}\text { Hours per Year } \\
\text { Above } 1.5\end{array}$ & $\begin{array}{c}\text { Hours per Year } \\
\text { Above } 2.0\end{array}$ & $\begin{array}{l}\text { Hours per Year } \\
\text { Above } 2.5\end{array}$ \\
\hline \multirow{4}{*}{ ZN2 } & BASELINE & 445 & 75 & 9 \\
\hline & IMPROVED & 396 & 67 & 5 \\
\hline & ENVELOPE & & & \\
\hline & HIGH-MASS & 271 & 27 & 0 \\
\hline \multirow{4}{*}{ ZN3 } & BASELINE & 489 & 89 & 17 \\
\hline & IMPROVED & 399 & 67 & 7 \\
\hline & ENVELOPE & & & \\
\hline & HIGH-MASS & 321 & 38 & 0 \\
\hline \multirow{4}{*}{ ZN4 } & BASELINE & 550 & 121 & 20 \\
\hline & IMPROVED & 430 & 72 & 8 \\
\hline & ENVELOPE & & & \\
\hline & HIGH-MASS & 282 & 27 & 0 \\
\hline
\end{tabular}

Table 5-4. Summary of Occupant Thermal Comfort Predictions on ASHRAE Thermal Sensation Scale for Heating in 24-Hour Offices: Envelope Change Models

\begin{tabular}{|c|c|c|c|c|}
\hline $\begin{array}{l}\text { Zone } \\
\text { Name }\end{array}$ & Scenario & $\begin{array}{c}\text { Hours per Year } \\
\text { Below } \\
-0.4\end{array}$ & $\begin{array}{c}\text { Hours per Year } \\
\text { Below } \\
-0.3\end{array}$ & $\begin{array}{c}\text { Hours per Year } \\
\text { Below } \\
-0.2\end{array}$ \\
\hline \multirow{4}{*}{ ZN1 } & BASELINE & 11 & 372 & 2051 \\
\hline & IMPROVED & 0 & 49 & 871 \\
\hline & ENVELOPE & & & \\
\hline & HIGH-MASS & 0 & 64 & 911 \\
\hline \multirow{3}{*}{ ZN8 } & BASELINE & 2 & 575 & 2614 \\
\hline & IMPROVED & 0 & 69 & 1402 \\
\hline & HIGH-MASS & 0 & 87 & 1471 \\
\hline
\end{tabular}

\subsection{Daylighting with Skylights}

This section presents an analysis of daylighting opportunity without altering the geometry of the building enclosure. Lighting controls are implemented that dim electric lights in response to the availability of daylight in the spaces. In this section the overall shape of the enclosure is not altered but flush-mounted, and horizontal skylights are added to allow daylight into the building. In Section 5.3, we further develop daylighting opportunities using overhangs and clerestories that do alter the shape of the building envelope.

Skylights were installed horizontally in the roof as shown in Figure 5-1. The figure also shows where the table-height daylight control sensors were placed in the zones. The rows of skylights in the east end of the building are located over an atrium open to ZN5 and ZN7. The floor and ceiling surfaces separating ZN5 and ZN7 were shortened to allow daylight to enter ZN5. The northern row of skylights was associated with ZN5, located on the first floor, underneath ZN7. The skylights use double-pane insulated glazing units with a low-e coating and argon gas fill. The low-e coating is also on a glazing layer with a composition tint (Azurlite ${ }^{\mathrm{TM}}$ ). 


\section{$\phi \quad$ Daylight sensor locations}

Skylights added to building for daylighting

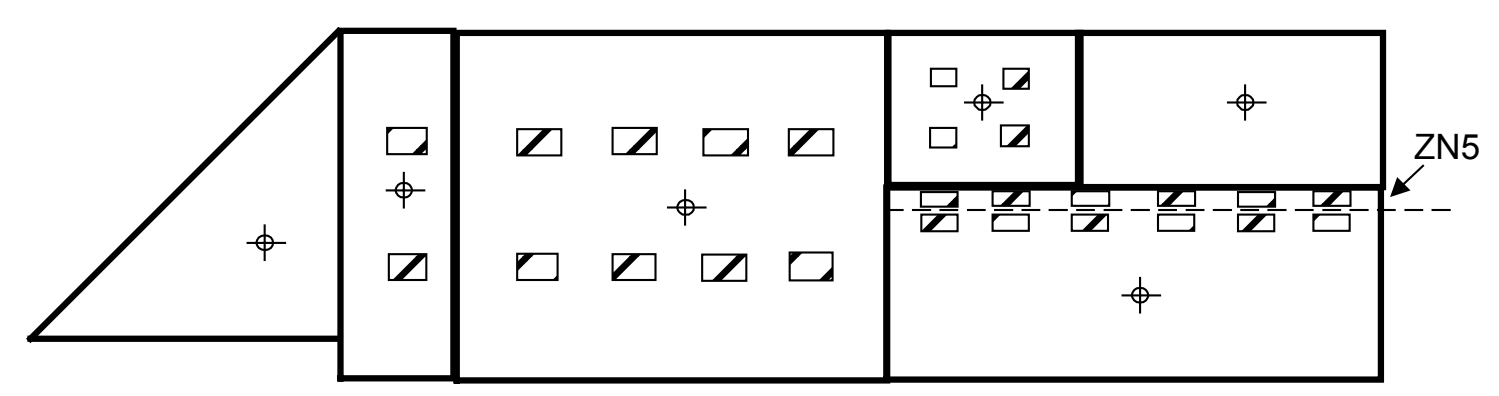

Figure 5-1. Roof plan: skylight layout

Implementing daylighting implies that electric lights are controlled to turn off when they are not needed. Table 5-5 lists the design lighting energy levels and fractions that we assumed to be dimmable for the daylighting models in this report. Table 5-6 summarizes energy-related results from the daylighting modeling with the added skylights. Table 5-7 gives the results for thermal comfort in the garage spaces, and Table 5-8 presents the results for thermal comfort in the 24-hour office spaces.

Table 5-5. Modeling of Lighting Controls for Daylighting

\begin{tabular}{llll}
\hline Zone Name & $\begin{array}{c}\text { Design Power Level } \\
\text { (W) }\end{array}$ & Fraction Replaceable & $\begin{array}{c}\text { Illuminance Threshold Set Point } \\
\text { (lux) }\end{array}$ \\
\hline ZN1 & 4160 & 0.8 & 500 \\
ZN2 & 4050 & 1.0 & 500 \\
ZN3 & 14850 & 1.0 & 500 \\
ZN4 & 3000 & 1.0 & 500 \\
ZN5 & 8450 & 0.8 & 500 \\
ZN6 & 4160 & 0.8 & 500 \\
ZN7 & 8450 & 0.8 & 500 \\
ZN8 & 4160 & 0.9 & 500 \\
\hline
\end{tabular}

Table 5-6. Summary of Results for Energy Use and Peak Loads: Daylighting with Skylights Models

\begin{tabular}{llll|lll}
\hline & Baseline & $\begin{array}{c}\text { Garages } \\
\text { Daylighting with } \\
\text { Skylights }\end{array}$ & \% & Baseline & $\begin{array}{c}\text { Offices } \\
\text { Daylighting with } \\
\text { Skylights }\end{array}$ & $\%$ \\
\hline $\begin{array}{l}\text { IDEAL HEATING } \\
\text { ENERGY (MWH/YR) }\end{array}$ & 318.6 & 336.1 & +5.5 & 38.7 & 19.5 & -49.6 \\
$\begin{array}{l}\text { IDEAL COOLING } \\
\begin{array}{l}\text { ENERGY (MWH/YR) } \\
\text { LIGHTING }\end{array}\end{array}$ & 0 & 0.0 & & 163.5 & 89.1 & -45.5 \\
$\begin{array}{l}\text { ELECTRICITY } \\
\text { (MWH/YR) }\end{array}$ & 133.5 & 50.6 & -62.1 & 117.5 & 69.1 & -41.2 \\
\hline $\begin{array}{l}\text { PEAK HEATING LOAD } \\
\text { (W) }\end{array}$ & 355,000 & 354,000 & -0.3 & 73,100 & 56,000 & -23.4 \\
$\begin{array}{l}\text { PEAK COOLING LOAD } \\
\text { (W) }\end{array}$ & 0.0 & 0 & & 121,00 & 72,800 & -39.8
\end{tabular}


PEAK AIR MASS

FLOW RATE

8.73

8.72

0.1

10.6

6.46

$-39.1$

Table 5-7. Summary of Occupant Thermal Comfort Predictions on ASHRAE Thermal Sensation Scale for Uncooled Garages and Shops: Daylighting with Skylights Model

\begin{tabular}{|c|c|c|c|c|}
\hline $\begin{array}{l}\text { Zone } \\
\text { Name }\end{array}$ & Scenario & $\begin{array}{l}\text { Hours per Year } \\
\text { Above } 1.5\end{array}$ & $\begin{array}{l}\text { Hours per Year } \\
\text { Above } 2.0\end{array}$ & $\begin{array}{l}\text { Hours per Year } \\
\text { Above } 2.5\end{array}$ \\
\hline & BASELINE & 445 & 75 & 9 \\
\hline ZN2 & $\begin{array}{l}\text { DAYLIGHTING WITH } \\
\text { SKYLIGHTS }\end{array}$ & 250 & 35 & 0 \\
\hline & BASELINE & 489 & 89 & 17 \\
\hline ZN3 & $\begin{array}{l}\text { DAYLIGHTING WITH } \\
\text { SKYLIGHTS }\end{array}$ & 260 & 40 & 0 \\
\hline & BASELINE & 550 & 121 & 20 \\
\hline ZN4 & $\begin{array}{l}\text { DAYLIGHTING WITH } \\
\text { SKYLIGHTS }\end{array}$ & 297 & 44 & 0 \\
\hline
\end{tabular}

Table 5-8. Summary of Occupant Thermal Comfort Predictions on ASHRAE Thermal Sensation Scale for Heating in 24-Hour Offices: Daylighting with Skylights Model

\begin{tabular}{lllll}
\hline Zone Name & \multicolumn{1}{c}{ Scenario } & $\begin{array}{c}\text { Hours per } \\
\text { Year Below } \\
-\mathbf{0 . 4}\end{array}$ & $\begin{array}{c}\text { Hours per Year } \\
\text { Below } \\
-\mathbf{0 . 3}\end{array}$ & $\begin{array}{c}\text { Hours per Year } \\
\text { Below } \\
\mathbf{0 . 2}\end{array}$ \\
\hline \multirow{2}{*}{ ZN1 } & BASELINE & 11 & 372 & 2051 \\
& DAYLIGHTING & 0 & 51 & 1047 \\
\hline \multirow{2}{*}{ ZN 8 } & WITH SKYLIGHTS & & & 2614 \\
& BASELINE & 2 & 575 & 1597 \\
\hline
\end{tabular}

\subsection{Overhangs and Clerestories}

Here we present results from models incorporating passive solar and daylighting strategies that use overhangs and clerestories. Overhangs are a well-known method of providing seasonally dependent shading and, therefore, solar heat gain. Modern glazing technologies offer products with low solar heat gain characteristics, quantified by the SHGC, that give the appearance of providing design solutions for reducing unwanted solar heat without overhangs. However, low-SHGC glazing does not guarantee that solar heat entering the building will not be excessive. The glazing means only that direct solar gains will be reduced by some percent. Overhangs can block that direct gain. Furthermore, low-SHGC glazing layers may absorb considerable solar heat, causing their interior surfaces to become warm, which leads to possible problems with occupant thermal comfort. Occupants sitting in direct sun are always likely to be uncomfortable. In buildings with heating load, such as the maintenance and garage areas for the Teterboro airport building, low-SHGC glazing will reduce solar heat gains that are actually desirable during the winter. A building that is designed to be sensitive to climate will allow heat gains in the winter but not in the summer, and overhangs on south-facing windows with high-SHGC windows are a good design solution. 
The latitude of the location can be used to determine appropriate dimensions for overhang design. Figure 5-2 shows recommended ratios for designing overhangs for windows facing south in Newark, New Jersey (Marion and Wilcox 1995). We used these ratios to design overhangs for south-facing windows in the energy simulations developed in this section.

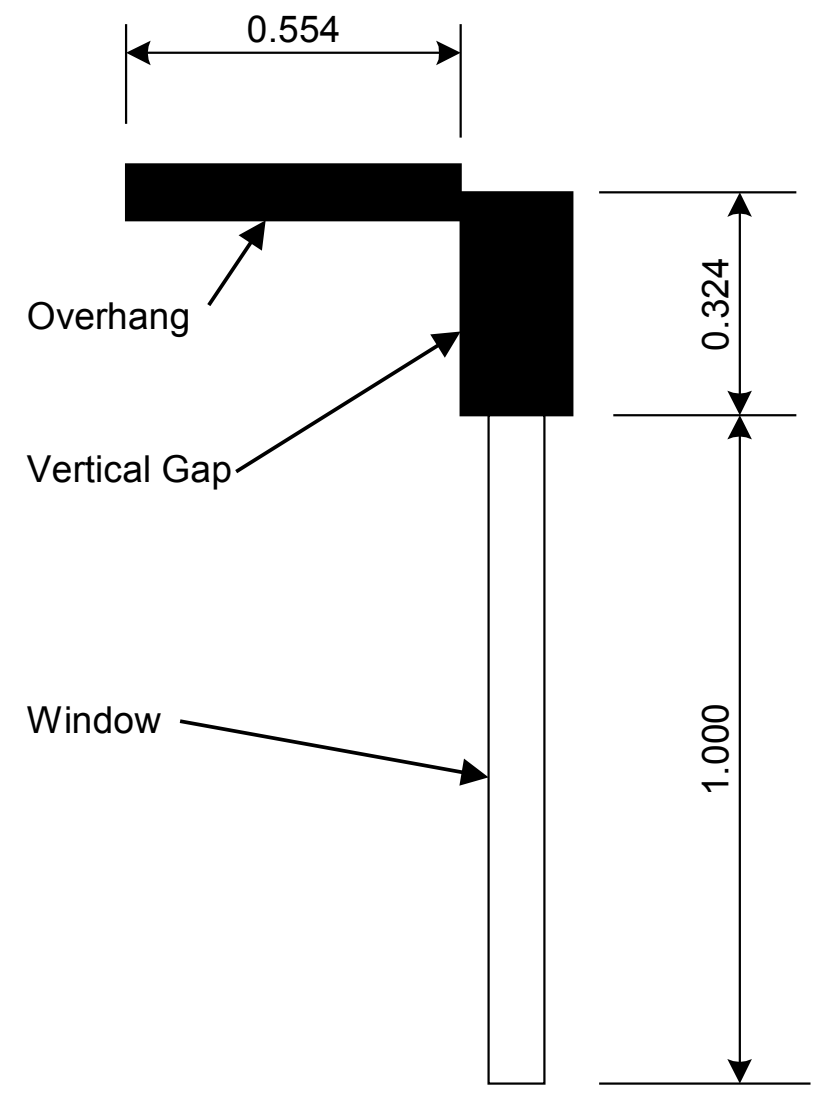

Figure 5-2. South-facing overhang design ratios, latitude $40.70 \mathrm{~N}$

To obtain good passive solar heating for zones that require significant heating, we increased south-facing glazing areas for garage zones and added overhangs to all south-facing glazing areas. Although offices still require cooling (after the morning warm-up), the garage and maintenance areas have high ventilation rates and low equipment loads. This makes using passive solar heating to meet heating loads desirable. The south-facing windows in these zones can use high-SHGC glazing $(\mathrm{SHGC}=0.55)$ as long as they are shaded from direct gains during the cooling season. Figure 5-3 diagrams the model with overhangs and clerestories. We added a long upper window and overhang to the southern exposure of the central garage area of ZN3, and altered the roofs of ZN2 and ZN3 to create large clerestories with south-facing glazing using crude sawtooth-shaped rooflines. Low-SHGC glazing $(\mathrm{SHGC}=0.175$ ) remains in use on office zones. Lighting levels and controls, given in Table 5-5, are the same as for the skylights. 


\section{\$ Daylight sensor locations}

ПП Sawtooth clerestories added to roof

OA Overhang added to south-facing windows

$\square \quad$ Skylights added to building for daylighting

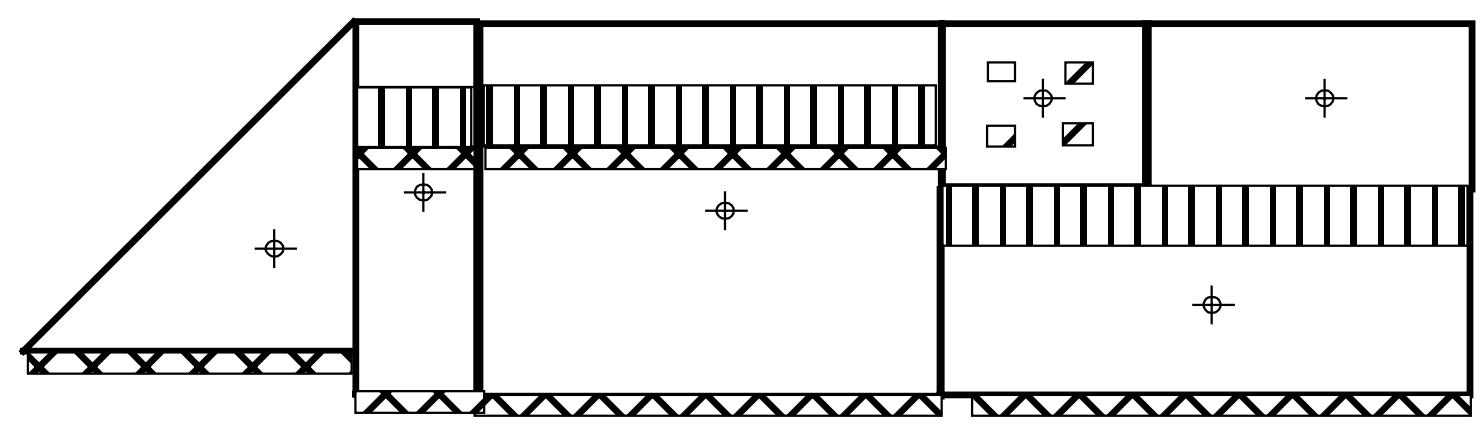

Roof plan schematic

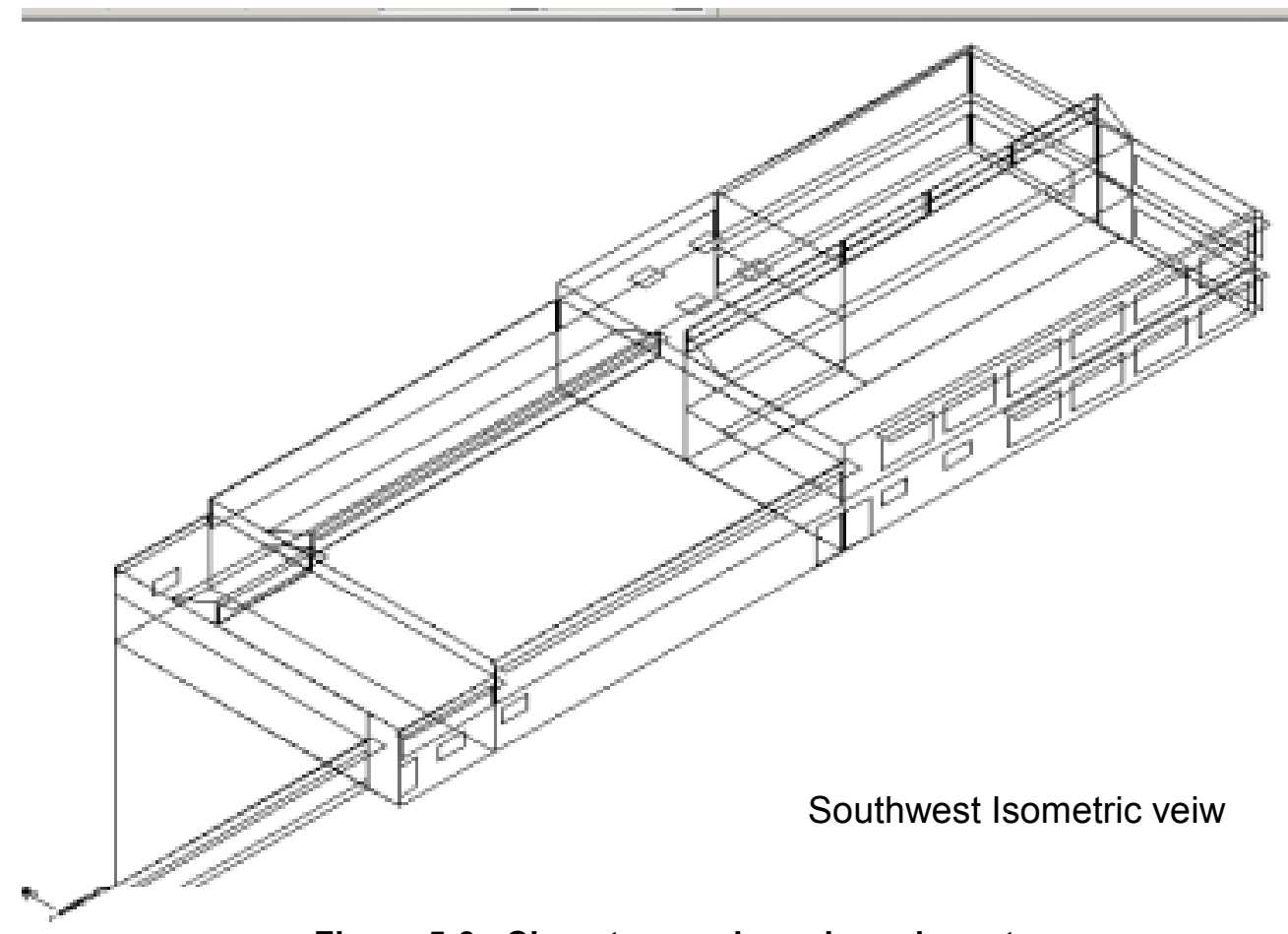

Figure 5-3. Clerestory and overhang layout

For the office zones, passive solar heating is not desirable because cooling is needed throughout the "heating" season. But because daylighting is advantageous, we added a north-facing clerestory above an atrium running along the center of the east end of the building office areas. A south-facing clerestory could be designed with overhangs to protect from direct solar gains, but north views may be desirable for this building because the airfield is that direction. A north-facing clerestory does not need an overhang. 
Figure 5-4 diagrams the north-facing clerestory and depicts how the atrium is modeled. EnergyPlus requires a one-to-one association between windows and zones for daylight calculations (but not solar thermal calculations). The clerestory glazing was subdivided and associated with different zones, as shown in Figure 5-4.

\begin{tabular}{|c|c|c|c|}
\hline ZN8 & ZN7 & ZN8 & ZN7 \\
\hline ZN6 & ZN5 & ZN6 & ZN5 \\
\hline
\end{tabular}

Front View (from North) of Clerestory Glazing Layout

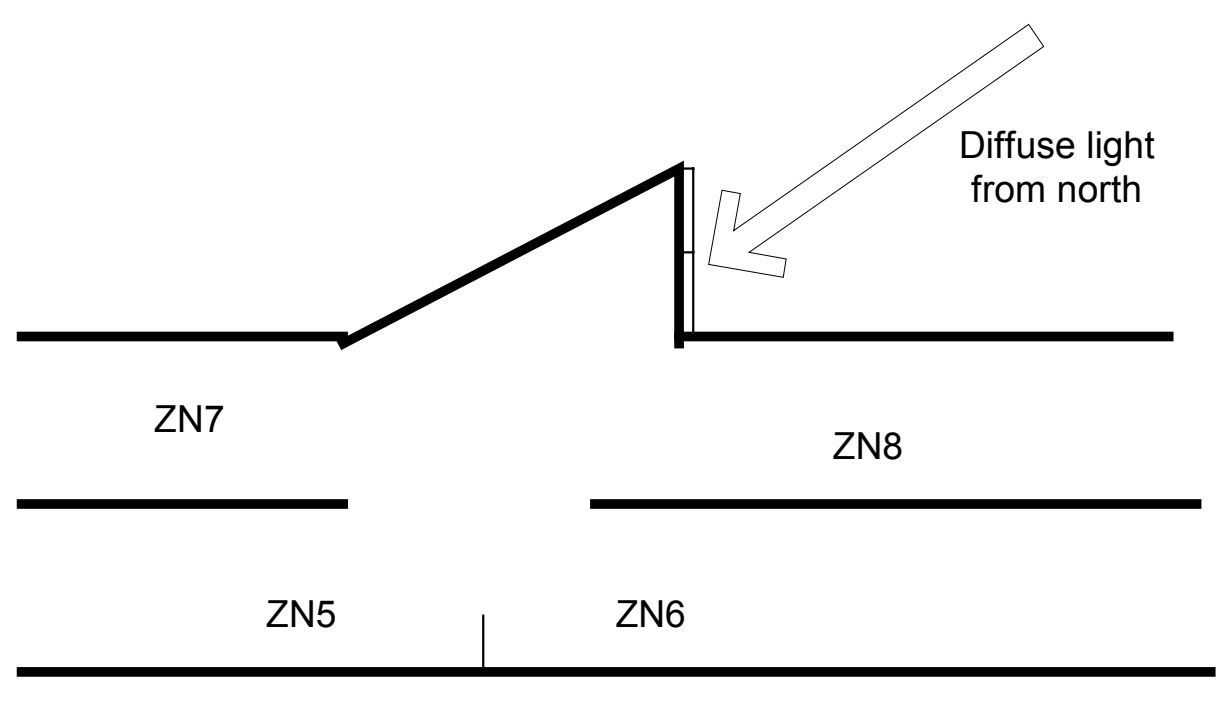

Section View (from East) of Zones and Clerestory

Figure 5-4. Atrium modeling for daylighting

Results for energy usage and peak system loads are given in Table 5-9, and Tables 5-10 and 5-11 show the results for predicted comfort levels. 
Table 5-9. Summary of Results for Energy Use and Peak Loads: Overhangs and Clerestories Model

\begin{tabular}{|c|c|c|c|c|c|c|}
\hline & Baseline & $\begin{array}{c}\text { Garages } \\
\text { Overhangs and } \\
\text { Clerestories }\end{array}$ & $\%$ & Baseline & $\begin{array}{c}\text { Offices } \\
\text { Overhangs and } \\
\text { Clerestories }\end{array}$ & $\%$ \\
\hline $\begin{array}{l}\text { IDEAL HEATING } \\
\text { ENERGY (MWH/YR) }\end{array}$ & 318.6 & 313.6 & -1.6 & 38.7 & 21.7 & -43.9 \\
\hline $\begin{array}{l}\text { IDEAL COOLING } \\
\text { ENERGY (MWH/YR) } \\
\text { LIGHTING }\end{array}$ & 0 & 0 & & 163.5 & 73.5 & -55.0 \\
\hline $\begin{array}{l}\text { ELECTRICITY } \\
(\mathrm{MWH} / \mathrm{YR})\end{array}$ & 133.5 & 64.6 & -51.6 & 117.5 & 57.9 & -50.7 \\
\hline $\begin{array}{l}\text { PEAK HEATING LOAD } \\
\text { (W) } \\
\text { PEAK COOLING }\end{array}$ & 355,000 & 346,000 & -2.5 & 73,100 & 55,600 & -23.9 \\
\hline $\begin{array}{l}\text { LOAD } \\
\text { (W) } \\
\text { PEAK AIR MASS }\end{array}$ & 0.0 & 0 & & 121,00 & 65,200 & -46.1 \\
\hline $\begin{array}{l}\text { FLOW RATE } \\
\text { (KG/S) }\end{array}$ & 8.73 & 8.52 & -2.4 & 10.7 & 5.78 & -46.0 \\
\hline
\end{tabular}

Table 5-10. Summary of Occupant Thermal Comfort Predictions on ASHRAE Thermal Sensation Scale for Uncooled Garages and Shops: Overhangs and Clerestories Model

\begin{tabular}{llllll}
\hline $\begin{array}{c}\text { Zone } \\
\text { Name }\end{array}$ & \multicolumn{1}{c}{ Scenario } & $\begin{array}{c}\text { Hours per } \\
\text { Year Above } \\
\mathbf{1 . 5}\end{array}$ & $\begin{array}{c}\text { Hours per } \\
\text { Year Above } \\
\mathbf{2 . 0}\end{array}$ & $\begin{array}{c}\text { Hours per Year } \\
\text { Above 2.5 }\end{array}$ \\
\hline \multirow{2}{*}{ ZN2 } & BASELINE & 445 & 75 & 9 & 0 \\
& OVERHANGS AND & 334 & 46 & 17 \\
& CLERESTORIES & & 49 & 0 \\
\multirow{2}{*}{ ZN3 } & BASELINE & 489 & 46 & 20 \\
& OVERHANGS AND & 311 & 46 & 0 \\
\hline \multirow{2}{*}{ ZN4 } & CLERESTORIES & BASELINE & 550 & 121 & 0 \\
& OVERHANGS AND & 299 & 44 & 0 \\
\hline
\end{tabular}


Table 5-11. Summary of Occupant Thermal Comfort Predictions on ASHRAE Thermal Sensation Scale for Heating in 24-Hour Offices: Overhangs and Clerestories Model

\begin{tabular}{|c|c|c|c|c|}
\hline $\begin{array}{l}\text { Zone } \\
\text { Name }\end{array}$ & Scenario & $\begin{array}{c}\text { Hours per } \\
\text { Year Below } \\
-0.4\end{array}$ & $\begin{array}{c}\text { Hours per Year } \\
\text { Below } \\
-0.3\end{array}$ & $\begin{array}{c}\text { Hours per Year } \\
\text { Below } \\
-0.2\end{array}$ \\
\hline \multirow[b]{2}{*}{$\mathrm{ZN} 1$} & BASELINE & 11 & 373 & 2051 \\
\hline & $\begin{array}{l}\text { OVERHANGS AND } \\
\text { CLERESTORIES }\end{array}$ & 0 & 47 & 1032 \\
\hline \multirow[b]{2}{*}{ ZN8 } & BASELINE & 2 & 572 & 2604 \\
\hline & $\begin{array}{l}\text { OVERHANGS AND } \\
\text { CLERESTORIES }\end{array}$ & 0 & 132 & 2213 \\
\hline
\end{tabular}

\subsection{Demand-Controlled Ventilation}

ASHRAE Standard 62-1999 (ASHRAE 1999) specifies ventilation requirements for commercial buildings. The prescriptive requirements for the garage/maintenance areas of the Teterboro Airport building are assumed to correspond to those of an automotive workshop at $7.5 \mathrm{~L} / \mathrm{s} \cdot \mathrm{m}^{2}$. This is a great deal of outdoor ventilation air that must be heated during winter months, using considerable fan power. As with other standards, ASHRAE 62-1999 allows for two methods of meeting requirements, a performance method and a prescriptive method. The prescriptive method in this case is maintaining a constant minimum ventilation rate at all times (because these areas operate 24 hours). Although the prescriptive method should ensure adequate indoor air quality (IAQ) in a well-mixed zone, it entails considerable energy use.

To meet the energy performance goals and ensure good IAQ, we recommend a performance method for ventilation. In this method, sensors are used to continuously monitor IAQ and adjust ventilation rates as needed. In addition, air delivery should be of the type known as "displacement ventilation," where fresh air is introduced low to the ground and subsequently leaves the space at or near the ceiling. This technique avoids complete mixing and results in good IAQ in industrial spaces. Displacement ventilation cannot be modeled well in current whole-building energy simulation programs. With detailed information on the configuration of sources of heat and pollutants, the effectiveness of displacement ventilation designs could be further analyzed with computational fluid dynamics. However, we present no further analysis of displacement ventilation in this report.

Incorporating sensors to control ventilation rates is referred to as "demand-controlled ventilation." With sensors to detect $\mathrm{CO}_{2}$, carbon monoxide, volatile organic compounds, and particulates, for example, the ventilation rates will vary depending on the activities occurring in the garages and shops. Because these activities and sources of air pollutants are not yet known for this specific project, we made the following assumptions to allow the energy implications of demand-controlled ventilation to be modeled at this early stage of the design process:

- Pollutant production varies directly with occupancy rates.

- Pollutant production is uniformly random.

- A minimum threshold of $25 \%$ of the prescriptive level of ventilation air is appropriate.

Based on these assumptions, we formulated new schedules for controlling the rates of introducing outdoor air into the garage and shop zones (ZN2, ZN3, and ZN4). Each zone is given a schedule for ventilation rates for every hour of the year based on Equation 5-1. The schedule yields a value for the fraction of 
design level that is to be used for a given hour. This design outdoor air rate is the prescriptive amount of ventilation air from ASHRAE 62-1999.

$f_{O A, i}=\operatorname{MAX}\left[0.25, f_{O C C P, i} * r_{u, i}\right]$

where

$f_{O A, i}$ is the fraction of design outdoor air at hour $i$

$f_{\text {OCCP,i }}$ is the fraction of design occupancy at hour $i$

$r_{u, i} \quad$ is the uniform pseudorandom number on [0..1] for hour $i$

$i \quad$ is hour of year.

$M A X[\quad]$ is the operator selecting higher of two parameters

We generated three independent, randomized schedules for the garage-type zones and added them to the model from Section 5.3 (overhangs and clerestories). This new model is termed "Demand-Controlled Ventilation." Table 5-12 summarizes the energy and load results for this model, and comfort results are summarized in Table 5-13.

Table 5-12. Summary of Results for Energy and Load in Demand-Controlled Garage/Shop/ARFF Spaces

\begin{tabular}{llll}
\hline & Baseline & $\begin{array}{c}\text { Demand- } \\
\text { Controlled } \\
\text { Ventilation }\end{array}$ & $\begin{array}{c}\% \\
\text { Change }\end{array}$ \\
\hline $\begin{array}{l}\text { IDEAL HEATING ENERGY } \\
\text { (MWH/YR) }\end{array}$ & 318.6 & 69.2 & -78.3 \\
$\begin{array}{l}\text { PEAK HEATING LOAD } \\
(\text { W) }\end{array}$ & 355,000 & 258,000 & -27.3 \\
$\begin{array}{l}\text { PEAK AIR MASS FLOW RATE } \\
(\text { KG/S })\end{array}$ & 8.73 & 6.35 & -27.3 \\
\hline
\end{tabular}

Table 5-13. Summary of Predictions for Occupant Thermal Comfort on ASHRAE Thermal Sensation Scale for Uncooled Garages and Shops: Demand-Controlled Ventilation and Baseline Performance Model

\begin{tabular}{|c|c|c|c|c|}
\hline $\begin{array}{l}\text { Zone } \\
\text { Name }\end{array}$ & Model & $\begin{array}{l}\text { Hours per Year } \\
\text { Above } 1.5\end{array}$ & $\begin{array}{l}\text { Hours per Year } \\
\text { Above } 2.0\end{array}$ & $\begin{array}{l}\text { Hours per Year } \\
\text { Above } 2.5\end{array}$ \\
\hline \multirow[b]{2}{*}{ ZN2 } & BASELINE & 445 & 75 & 9 \\
\hline & $\begin{array}{l}\text { DEMAND-CONTROLLED } \\
\text { VENTILATION }\end{array}$ & 638 & 82 & 1 \\
\hline \multirow[b]{2}{*}{ ZN3 } & BASELINE & 489 & 89 & 17 \\
\hline & $\begin{array}{l}\text { DEMAND-CONTROLLED } \\
\text { VENTILATION }\end{array}$ & 517 & 57 & 0 \\
\hline \multirow[b]{2}{*}{ ZN4 } & BASELINE & 550 & 121 & 20 \\
\hline & $\begin{array}{l}\text { DEMAND-CONTROLLED } \\
\text { VENTILATION }\end{array}$ & 500 & 52 & 0 \\
\hline
\end{tabular}




\subsection{HVAC Systems}

This section presents modeling results where we specified HVAC systems so that we can predict the building's energy use and cost. The first subsection focuses on office zones that are conditioned using rooftop-packaged units, and the second subsection discusses heating and ventilating garage zones.

\subsubsection{Office Zone DX Equipment}

Rooftop-packaged units offer economic advantages for smaller commercial buildings. The units we considered here are mid-sized industrial rooftop-packaged units with cooling provided by DX cooling coils. The Baseline Energy Model presented in Section 3.0 uses five separate constant-volume, rooftoppackaged units, one for each zone. This system serves as a starting point.

EnergyPlus allows performance details of particular HVAC systems and components to be specified. More often than not, DX equipment is operating under conditions that differ from conditions under which the equipment was rated. EnergyPlus allows using performance curves that are input explicitly rather than relying on defaults hard-coded into the program's models. Each DX cooling coil uses four performance curves and a fifth part-load curve. Because equipment-specific data for generating part-load curve are difficult to obtain, we used a single curve recommended by a manufacturer for a separate modeling exercise (Neymark and Judkoff 2002) for all of the DX system models. Two of the performance curves are biquadratic curves, one for capacity and one for energy input ratio (EIR), as a function of two different air temperatures, one entering the evaporator and the other entering the condenser. EIR is the inverse of COP. The other two performance curves are second-order quadratic curves for capacity and EIR, as a function of airflow rate through the coil. The performance curves were generated from manufacturer performance data tables (Carrier Corporation, Syracuse, New York; 2002) using function-fitting routines from a commercial mathematics program (Wolfram 1999). The curves are documented and available in the EnergyPlus input files. See Appendix E for more information on how we generated the performance curves.

The first step in developing energy use and cost results is to attach the same DX system used in the Baseline Energy Model to the building form, function, and fabric developed through the Overhangs and Clerestories Model discussed in Section 5.3. This model includes envelope improvements, daylighting via clerestories, and overhangs over south-facing glazing. All four of the modeling steps in this section use this building description with different HVAC systems. Table 5-14 shows energy use and Table 5-15 presents energy cost results for these simulations. Table 5-16 compares comfort predictions for the different systems.

Table 5-14. Summary of Results for Energy Use for Office Zones with Constant-Volume DX Rooftop-Packaged Units

\begin{tabular}{|c|c|c|c|c|c|c|c|}
\hline & $\begin{array}{l}\text { Lights } \\
\text { (MWh/yr) }\end{array}$ & $\begin{array}{c}\text { Equipment } \\
\text { (MWh/yr) }\end{array}$ & $\begin{array}{c}\text { Fans } \\
\text { (MWh/yr) }\end{array}$ & $\begin{array}{l}\text { Cooling } \\
\text { (MWh/yr) }\end{array}$ & $\begin{array}{l}\text { Heating } \\
\text { (MWh/yr) }\end{array}$ & $\begin{array}{l}\text { Total w/o } \\
\text { equipment } \\
\text { (MWh/yr) }\end{array}$ & $\begin{array}{c}\text { Intensity } \\
(\mathrm{kWh} / \\
\left.\mathrm{m}^{2} \cdot \mathrm{yr}\right) \\
\end{array}$ \\
\hline $\begin{array}{l}\text { BASELINE } \\
\text { AVERAGE }\end{array}$ & 117.5 & 95.1 & 61.0 & 51.0 & 86.6 & 316.1 & 150.6 \\
\hline OVERSIZED DX & 57.9 & 95.1 & 61.0 & $\begin{array}{l}33.3 \\
(-34.7 \%)\end{array}$ & $\begin{array}{l}58.8 \\
(-32.1 \%)\end{array}$ & $\begin{array}{l}211.1 \\
(-33.2 \%)\end{array}$ & 100.6 \\
\hline DOWNSIZED DX & 57.9 & 95.1 & 35.3 & $\begin{array}{l}29.7 \\
(-41.8 \%)\end{array}$ & $\begin{array}{l}75.1 \\
(-13.3 \%)\end{array}$ & $\begin{array}{l}198.0 \\
(-37.4 \%)\end{array}$ & 94.3 \\
\hline $\begin{array}{l}\text { DOWNSIZED DX + } \\
\text { HRV }^{*}\end{array}$ & 57.9 & 95.1 & 35.3 & $\begin{array}{l}30.5 \\
(-40.2 \%)\end{array}$ & $\begin{array}{l}26.4 \\
(-69.5 \%)\end{array}$ & $\begin{array}{l}150.1 \\
(-52.5 \%)\end{array}$ & 71.5 \\
\hline $\begin{array}{l}\text { HIGH-EFFICIENCY } \\
\text { DOWNSIZED DX + } \\
\text { HRV* }^{*}\end{array}$ & 57.9 & 95.1 & 35.3 & $\begin{array}{l}23.1 \\
(-54.7 \%)\end{array}$ & $\begin{array}{l}12.6 \\
(-85.5 \%)\end{array}$ & $\begin{array}{l}129 \\
(-59.2 \%)\end{array}$ & 61.4 \\
\hline
\end{tabular}

${ }^{*} \mathrm{HRV}$ : heat recovery ventilators. 
Table 5-15. Summary of Results for Energy Cost for Office Zones with Constant-Volume DX Rooftop-Packaged Units

\begin{tabular}{|c|c|c|c|c|c|c|c|}
\hline & $\begin{array}{c}\text { Lights } \\
\text { (\$/yr) }\end{array}$ & $\begin{array}{l}\text { Equipment } \\
\text { (\$/yr) }\end{array}$ & $\begin{array}{l}\text { Fans } \\
(\$ / y r)\end{array}$ & $\begin{array}{l}\text { Cooling } \\
\text { (\$/yr) }\end{array}$ & $\begin{array}{l}\text { Heating } \\
\text { (\$/yr) }\end{array}$ & $\begin{array}{c}\text { Total w/o } \\
\text { Equipment } \\
\text { (\$/yr) }\end{array}$ & $\begin{array}{l}\text { Intensity } \\
\left(\$ / m^{2} \cdot y r\right)\end{array}$ \\
\hline BASELINE AVERAGE & 19,770 & 15,934 & 10,065 & 8,565 & 2,588 & 40,983 & 19.72 \\
\hline OVERSIZED DX & 9,577 & 15,934 & 10,065 & 5,821 & 1,809 & $\begin{array}{l}27,267 \\
(-33.5 \%)\end{array}$ & 12.99 \\
\hline DOWNSIZED DX & 9,577 & 15,934 & 5,827 & 5,185 & 2,309 & $\begin{array}{l}22,898 \\
(-44.1 \%)\end{array}$ & 10.91 \\
\hline DOWNSIZED DX + HRV & 9,577 & 15,934 & 5,827 & 5,314 & 812 & $\begin{array}{l}21,530 \\
(-47.5 \%)\end{array}$ & 10.26 \\
\hline $\begin{array}{l}\text { HIGH-EFFICIENCY } \\
\text { DOWNSIZED DX + HRV }\end{array}$ & 9,577 & 15,934 & 5,827 & 4,069 & 812 & $\begin{array}{l}20,285 \\
(--50.5 \%)\end{array}$ & 9.66 \\
\hline
\end{tabular}

The Oversized DX Model uses the same DX equipment as the Baseline Energy Model except that the DX coil models were based on actual 90.1-compliant products. For the Baseline Energy Model, we used the lower rated COPs of 3.1 and 3.2 as the specified minimums from 90.1-2001(g). For the standardefficiency systems, we selected specific units (Carrier models 48TM008 and 48TM014) that have rated COPs of 3.76 and 3.48, respectively. The capacity and efficiency performance curves in the Baseline Energy Model were those that correspond to these specific models. The standard-efficiency DX units were suitable for the Baseline Energy Model but become "oversized" once other building improvements are made.

The Downsized DX Model uses smaller, standard-efficiency DX equipment based on the results of separate, design-day sizing simulations using EnergyPlus. The improved envelope and daylighting controls allow the size of installed HVAC equipment to be reduced. The sizing runs (not presented) showed that the two nominal 14-ton units can be replaced with 12-ton units and the three nominal 7-1/2ton units could be replaced by 4-ton units. We selected specific downsized DX units (Carrier models 48TM005 and 48TM012) with rated COPs of 3.2 and 3.76, respectively. Capacity and efficiency curves were changed as well to match published performance data for these systems.

The Downsized DX + HRV Model uses the same DX equipment but adds heat recovery equipment to the outdoor air system. The recovery systems are modeled as $62 \%$ effective, counterflow, flat-plate, air-to-air heat exchangers. These heat exchangers exchange only sensible heat and are always on. (No enthalpy wheel models are currently available in EnergyPlus).

The High-Efficiency Downsized DX + HRV Model uses the same configuration as the previous model, but replaces the standard-efficiency DX equipment with higher efficiency equipment. We selected specific new DX units (Carrier models 48HJ005 and 48HJ012) with rated COPs of 3.92 and 3.97, respectively. Capacity and efficiency curves were changed as well to match published performance data for these systems.

Table 5-16. Summary of Predictions for Occupant Thermal Comfort on ASHRAE Thermal Sensation Scale for 24-Hour Office: ZN1

\begin{tabular}{|c|c|c|c|c|c|}
\hline Model & $\begin{array}{c}\text { Hours per } \\
\text { Year Below } \\
-1.0\end{array}$ & $\begin{array}{c}\text { Hours per } \\
\text { Year Below } \\
-0.5\end{array}$ & $\begin{array}{c}\text { Hours per } \\
\text { Year Above } \\
+0.5\end{array}$ & $\begin{array}{c}\text { Hours per } \\
\text { Year Above } \\
+1.0\end{array}$ & $\begin{array}{c}\text { Hours per } \\
\text { Year Above } \\
+2.0 \\
\end{array}$ \\
\hline BASELINE & 0 & 1332 & 3584 & 293 & 0 \\
\hline OVERSIZED DX & 0 & 269 & 3261 & 0 & 0 \\
\hline
\end{tabular}




\begin{tabular}{llllll} 
DOWNSIZED DX & 0 & 274 & 3254 & 0 & 0 \\
DOWNSIZED DX + HRV & 0 & 273 & 3264 & 0 & 0 \\
HIGH-EFFICIENCY & 0 & 237 & 3519 & 2 & 0 \\
DOWNSIZED DX + HRV & 0 & & 279 \\
\hline
\end{tabular}

\subsubsection{Garage Zone Heater/Ventilators}

The garage spaces are heated and ventilated by three separate rooftop-packaged units. The Baseline Energy Model presented in Section 3.0 uses constant-volume, gas-fired heaters with outdoor air economizers. Because the airflow rates are dictated by ventilation requirements rather than air system requirements for space thermal conditioning, air systems are not downsized. The EnergyPlus models of these systems were built up from components in a similar manner as the rooftop DX systems but without the cooling coils. Efforts to model the systems using unit ventilator heater models were unsuccessful because these models are implemented for space conditioning rather than ventilation for IAQ.

The first step in developing energy use and cost results is to attach the same heater/ventilator system used in the Baseline Energy Model to the building form, function, and fabric developed through the Overhangs and Clerestories Model discussed in Section 5.3. This model includes envelope improvements, daylighting via clerestories, and passive solar heating with high-SHGC glazing underneath overhangs. All three of the modeling steps in this section use this building description and substitute in different HVAC systems. Table 5-17 shows energy use and Table 5-18 presents the energy cost results for these simulations. Table 5-19 compares comfort predictions for the different systems.

Table 5-17. Summary of Results for Energy Use in Garage Zones

\begin{tabular}{|c|c|c|c|c|c|c|}
\hline & $\begin{array}{l}\text { Lights } \\
\text { (MWh/yr) }\end{array}$ & $\begin{array}{c}\text { Equipment } \\
\text { (MWh/yr) }\end{array}$ & $\begin{array}{c}\text { Fans } \\
\text { (MWh/yr) }\end{array}$ & $\begin{array}{c}\text { Heating } \\
\text { (MWh/yr) }\end{array}$ & $\begin{array}{c}\text { Total w/o } \\
\text { Equipment } \\
\text { (MWh/yr) }\end{array}$ & $\begin{array}{c}\text { Intensity } \\
\left(\mathrm{kWh} / \mathrm{m}^{2} \cdot \mathrm{yr}\right)\end{array}$ \\
\hline BASELINE AVERAGE & 133.5 & 24.2 & 78.8 & 320.5 & 532.8 & 392.6 \\
\hline $\begin{array}{l}\text { IMPROVED BUILDING } \\
\text { PRESCRIPTIVE VENTILATION }\end{array}$ & 64.6 & 24.2 & 78.8 & 319.4 & $\begin{array}{l}462.8 \\
(-13.1 \%)\end{array}$ & 314.1 \\
\hline $\begin{array}{l}\text { DEMAND-CONTROLLED } \\
\text { VENTILATION }\end{array}$ & 64.6 & 24.2 & 78.8 & 50.3 & $\begin{array}{l}193.7 \\
(-63.6 \%)\end{array}$ & 142.8 \\
\hline $\begin{array}{l}\text { DEMAND-CONTROLLED } \\
+ \text { HEAT RECOVERY }\end{array}$ & 64.6 & 24.2 & 78.8 & 1.7 & $\begin{array}{l}144.3 \\
(-72.9 \%)\end{array}$ & 106.3 \\
\hline
\end{tabular}

Table 5-18. Summary of Energy Cost Results for Garage Zones

\begin{tabular}{|c|c|c|c|c|c|c|}
\hline & $\begin{array}{c}\text { Lights } \\
\text { (\$/yr) }\end{array}$ & $\begin{array}{l}\text { Equipment } \\
\text { (\$/yr) }\end{array}$ & $\begin{array}{l}\text { Fans } \\
\text { (\$/yr) }\end{array}$ & $\begin{array}{l}\text { Heating } \\
\text { (\$/yr) }\end{array}$ & $\begin{array}{c}\text { Total w/o } \\
\text { Equipment } \\
\text { (\$/yr) }\end{array}$ & $\begin{array}{l}\text { Intensity } \\
\left(\$ / \mathrm{m}^{2} \cdot \mathrm{yr}\right)\end{array}$ \\
\hline BASELINE AVERAGE & 22,260 & 4,032 & 13,030 & 9,854 & \multirow{4}{*}{$\begin{array}{l}45,330 \\
33,363 \\
(-26.4 \%) \\
25,265 \\
(-44.3 \%) \\
23,454 \\
(-48.3 \%) \\
\end{array}$} & 33.40 \\
\hline $\begin{array}{l}\text { IMPROVED BUILDING PRESCRIPTIVE } \\
\text { VENTILATION }\end{array}$ & 10,510 & 4,032 & 13,030 & 9,823 & & 24.60 \\
\hline DEMAND-Controlled VENTILATION & 10,510 & 4,032 & 13,030 & 1,739 & & 18.62 \\
\hline $\begin{array}{l}\text { DEMAND-CONTROLLED } \\
+ \text { HEAT RECOVERY }\end{array}$ & 10,510 & 4,032 & 12,895 & 51 & & 17.30 \\
\hline
\end{tabular}

The Improved Building Prescriptive Ventilation Model uses the same HVAC system as the Baseline Energy Model but with the improved building described in Section 5.3. This model includes daylighting and passive solar designs. 
The Demand-Controlled Ventilation Model uses the same HVAC system but reduces outdoor ventilation rates in an effort to simulate how a sensor-based ventilation system might perform, as discussed in Section 5.4.

The Demand-Controlled + HRV Model adds air-to-air heat recovery ventilation equipment. These systems are modeled as $62 \%$ effective, counterflow, flat-plate, air-to-air heat exchangers. These heat exchangers exchange only sensible heat, and have much larger nominal flow rates than the units for the offices.

Table 5-19. Summary of Predictions for Occupant Thermal Comfort on ASHRAE Thermal Sensation Scale for 24-Hour Garages: ZN3

\begin{tabular}{lllllll}
\hline \multicolumn{1}{c}{ Model } & $\begin{array}{c}\text { Hours per } \\
\text { Year } \\
\text { Below } \\
\mathbf{- 2 . 0}\end{array}$ & $\begin{array}{c}\text { Hours per } \\
\text { Year } \\
\text { Below } \\
\mathbf{- 1 . 0}\end{array}$ & $\begin{array}{c}\text { Hours per } \\
\text { Year } \\
\text { Below } \\
\mathbf{- 0 . 5}\end{array}$ & $\begin{array}{c}\text { Hours per } \\
\text { Year } \\
\text { Above } \\
\mathbf{+ 0 . 5}\end{array}$ & $\begin{array}{c}\text { Hours per } \\
\text { Year } \\
\text { Above } \\
\mathbf{+ 1 . 0}\end{array}$ & $\begin{array}{c}\text { Hours per } \\
\text { Year } \\
\text { Above } \\
\mathbf{+ 2 . 0}\end{array}$ \\
\hline $\begin{array}{l}\text { BASELINE } \\
\text { IMPROVED BUILDING }\end{array}$ & 3202 & 4639 & 5132 & 2229 & 1399 & 145 \\
$\begin{array}{l}\text { PRESCRIPTIVE } \\
\text { VENTILATION }\end{array}$ & 3114 & 4643 & 5167 & 2051 & 1202 & 71 \\
$\begin{array}{l}\text { DEMAND-CONTROLLED } \\
\text { VENTILATION }\end{array}$ & 3119 & 4641 & 5144 & 2423 & 1765 & 195 \\
$\begin{array}{l}\text { DEMAND- CONTROLLED } \\
+ \text { HEAT RECOVERY }\end{array}$ & 2162 & 4438 & 4733 & 3501 & 3317 & 1483 \\
\hline
\end{tabular}




\subsection{Renewable Electricity Production}

Generating electricity using clean, renewable solar electric panels may be desirable for this project. This section presents an analysis of the amount of electricity that could be produced by a photovoltaic (PV) system at the Teterboro site.

\subsection{Photovoltaic Modeling in PVSyst}

We predicted the annual energy production from a PV system for the Teterboro site using a model of the entire PV system with the simulation program PVSYST Version 3.2 (Mermond 2002). Inputs to this model include PV panel size and manufacturer, array wiring configuration and associated losses, array tilt and azimuth, hourly weather data, and inverter size and type. The model also simulates system-specific inputs, such as isolation transformer losses and array wiring losses.

The PV system modeled in PVSyst was a 20-kWp, 3-phase grid-tied system with no battery storage. The modules used for this system were monocrystalline BP Solar 80-Wp panels (BP Solar, Linthicum, Maryland; 2001). With 16 modules in series and 16 strings in parallel, the entire array is rated at 20.5$\mathrm{kWp}(393$ volts direct current [DC] and $81 \mathrm{amps}$ ) at the peak output under standard test conditions. An $18-\mathrm{kW}$, grid-tied, inverter was selected along with an energy efficient isolation transformer. This inverter/transformer model includes a maximum power point tracker and the $97 \%$ efficient isolation transformer. Figure 6-1 is a diagram of the proposed system.

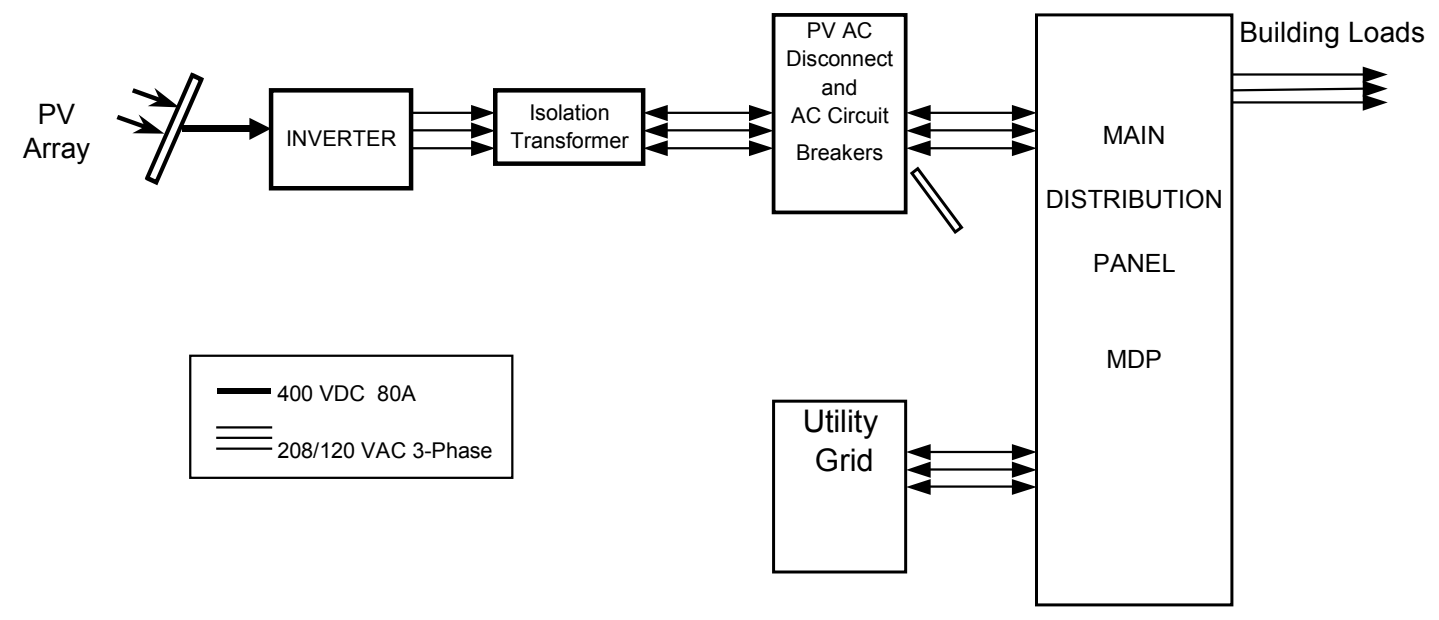

Figure 6-1. 20-kWp PV system schematic

This PV model includes associated system losses that are summarized in Figure 6-2. At an insolation level of $800 \mathrm{~W} / \mathrm{m}^{2}$ and an ambient temperature of $20^{\circ} \mathrm{C}$, the largest system degradation from theoretical results from module thermal losses. Under these operating conditions, the model predicts cell temperatures of $45^{\circ} \mathrm{C}$. As the cell temperature increases, the module output decreases. These thermal losses are $9.3 \%$ of the theoretical maximum. 


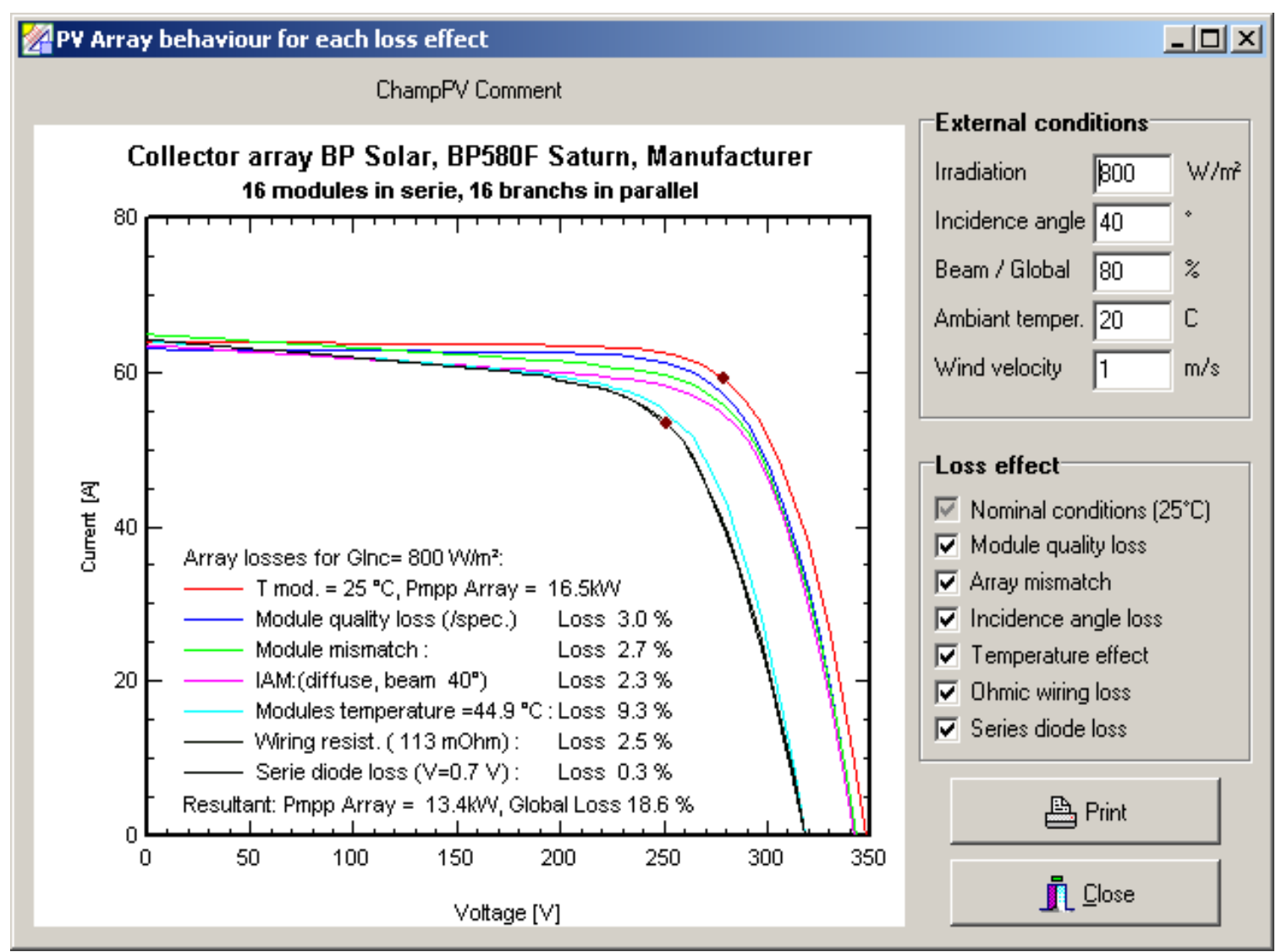

Figure 6-2. Current-voltage curves of system losses and performance at expected environmental conditions

Typical meteorological year (TMY) weather data for New York City (Newark would have been a better choice because the building is closer to it, but the building location is almost between the two cities.) were used to model the expected annual performance. To determine the optimal angle, we simulated the described PV system at an azimuth of 0.0 (array facing south) and at varying tilt angles. As shown in Figure 6-3, the annual alternating current (AC) PV output is plotted versus a range of tilt angles from $0.0^{\circ}$ to $90.0^{\circ}$. The results indicate that the optimal tilt angle is $32^{\circ}$. At this angle, the PV system is predicted to produce $26,285 \mathrm{kWh} / \mathrm{yr}$. For tilt angles between $10^{\circ}$ and $50^{\circ}$, the annual performance is degraded by less than $6.0 \%$ as compared to the optimal tilt performance. Table 6-1 summarizes the monthly performance at an array tilt of $32^{\circ}$ for a $20-\mathrm{kWp}$ PV system. The difference in seasonal insolation is the primary reason for an optimal array tilt that is less than the site latitude. As shown in Figure 6-4, the distribution of insolation for the summer months between the equinoxes is at higher bins of global horizontal insolation, and the total insolation distribution for the winter months between the equinoxes is at the lower end of the insolation bins. Because the summer months have higher solar altitude angles, the PV array tilt is optimized to take full advantage of the high summer insolation by reducing tilt to $32^{\circ}$ from the latitude tilt of $41^{\circ}$. 


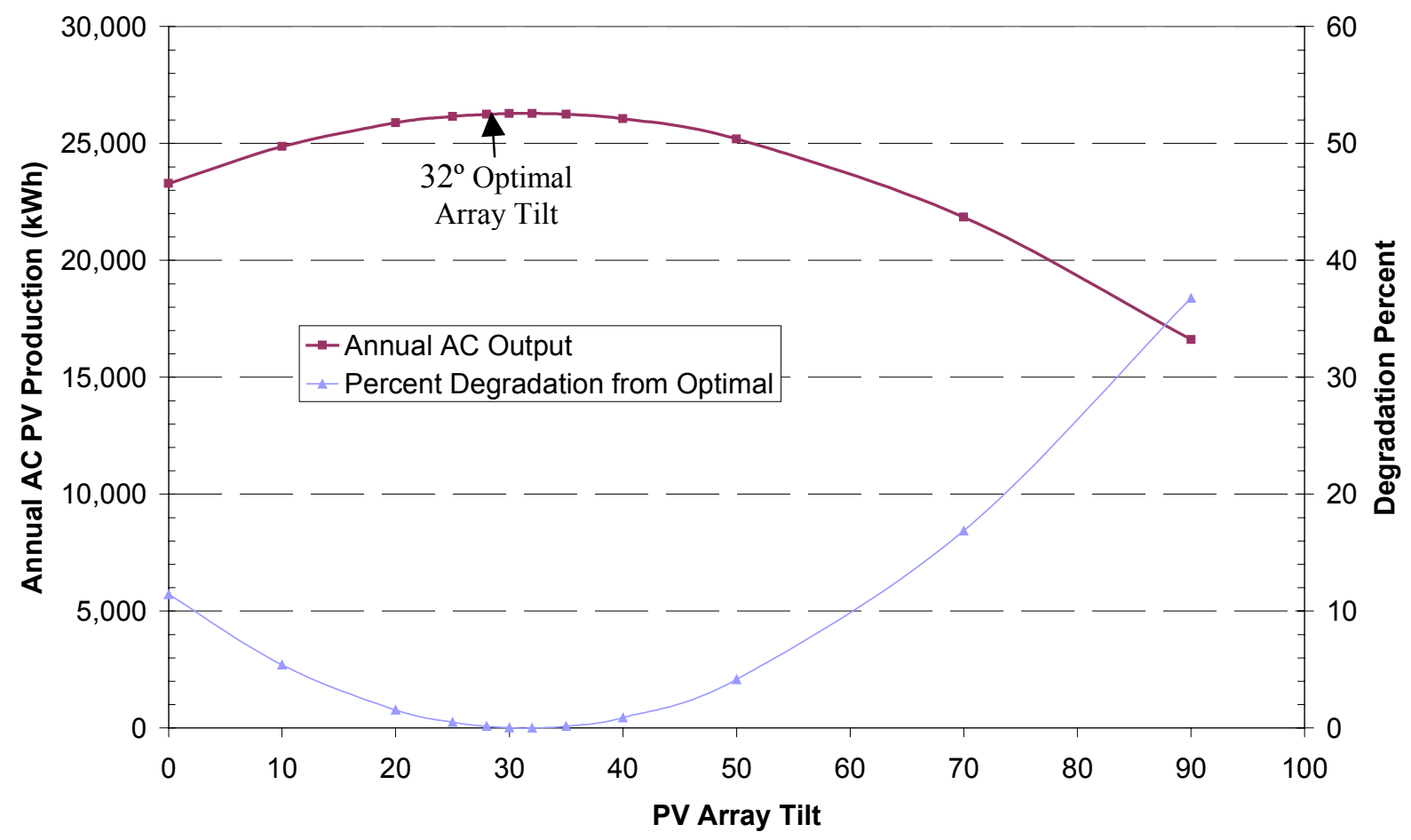

Figure 6-3. PV array tilt optimization

Table 6-1. Summary of Predicted PV Performance by Month: $32^{\circ}$ Tilt

\begin{tabular}{llllll}
\hline & $\begin{array}{c}\text { Total Horizontal } \\
\text { Insolation } \\
\left(\mathbf{k W h} / \mathbf{m}^{2}\right)\end{array}$ & $\begin{array}{c}\text { Total Insolation on } \\
\mathbf{C o l l e c t o r} \\
\left(\mathbf{k W h} / \mathbf{m}^{\mathbf{2}}\right)\end{array}$ & $\begin{array}{c}\text { DC PV } \\
\text { Energy } \\
\mathbf{( k W h )}\end{array}$ & $\begin{array}{c}\text { AC PV } \\
\text { Energy } \\
\mathbf{( k W h )}\end{array}$ & $\begin{array}{c}\text { System Conversion } \\
\text { Efficiency } \\
\mathbf{( \% )}\end{array}$ \\
\hline JANUARY & 58 & 87.2 & 1686 & 1553 & 11.1 \\
FEBRUARY & 76 & 100.5 & 1945 & 1794 & 11.1 \\
MARCH & 116 & 140.6 & 2669 & 2462 & 10.9 \\
APRIL & 142 & 148.9 & 2745 & 2534 & 10.6 \\
MAY & 176 & 170.4 & 3019 & 2786 & 10.1 \\
JUNE & 180 & 168.4 & 2922 & 2697 & 9.9 \\
JULY & 181 & 170.5 & 2886 & 2662 & 9.7 \\
AUGUST & 168 & 169.9 & 2907 & 2685 & 9.8 \\
SEPTEMBER & 130 & 146.0 & 2552 & 2356 & 10.0 \\
OCTOBER & 99 & 131.1 & 2380 & 2196 & 10.4 \\
NOVEMBER & 56 & 81.7 & 1515 & 1395 & 10.6 \\
DECEMBER & 46 & 66.6 & 1269 & 1165 & 10.9 \\
\hline TOTAL & 1428 & 1581.8 & 28495 & 26285 & 10.3 \\
\hline
\end{tabular}




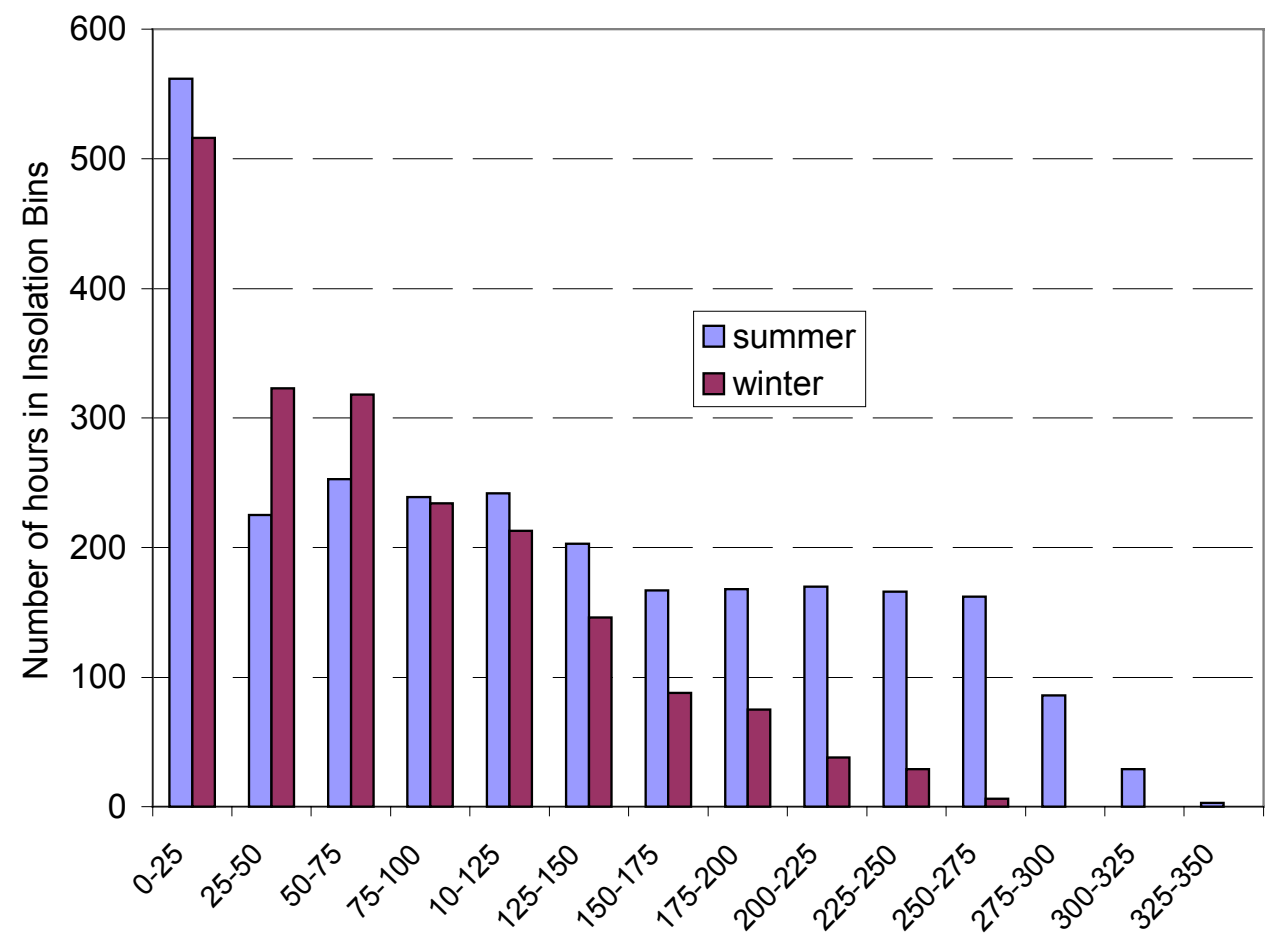

Daytime Global Horizontal Insolation Bins (Btu/hrft2)

Figure 6-4. Global horizontal insolation histogram by season

\subsection{Photovoltaic Modeling in EnergyPlus}

EnergyPlus includes a link to TRNSYS for modeling PV systems that allows the same weather file to be used and the results to be reported in combination. We modeled a PV system that corresponds to the system modeled above; however, the results were obviously erroneous and are not presented. This may be related to known problems in EnergyPlus that have since been corrected. 


\subsection{Discussion of Modeling Results}

This section discusses results presented in Sections 5.0 and 6.0. To compute energy savings from design measures, we used results from the baseline analyses discussed in Section 3.0. The baseline average results are the average of four results obtained by rotating the model's north axis through the four cardinal directions. When discussing reductions and savings using percent values, we used Equation 7-1 to compute percentages. Electricity for equipment, or plug loads, is not included in totals when comparing overall energy usage and reductions. However, these internal loads are included in the energy models.

$$
\frac{[(\text { Baseline Avg.value })-(\text { New value })]}{(\text { Baseline Avg. value })} / 100
$$

\subsection{Envelope}

Section 5.1 presented modeling results related to improving the thermal envelope. Envelope improvements analyzed included increasing the thermal insulation and mass for opaque elements and utilizing higher performance glazing systems with lower U-factors and SHGCs. We modeled two versions of envelope improvement. The improved envelope version did not significantly change the exposure of the interior air to thermal mass. The high-mass model exposed thermal mass by using tiled floors instead of carpet and using walls with concrete block adjacent to interior spaces with foam insulation situated on the outside of exterior walls and in the middle of interior walls. Results showed that increasing the thermal performance of envelope components could reduce energy use and the peak loads that equipment must meet.

For the garage spaces, the amount of heating energy the air system needs to deliver to the spaces decreased by $2.8 \%$ for the improved envelope and $3.5 \%$ for the high-mass model. Maximum heating load was also reduced by $2.8 \%$ for the improved envelope and by $3.4 \%$ for the high-mass model. Results show that the envelope improvements enhance thermal comfort compared to the Baseline Building Performance Model. The high-mass model would be expected to be considerably more comfortable than the low-mass model.

For the office spaces, the amount of cooling energy the air system needs to deliver to the spaces decreased by $14.4 \%$ for the improved envelope and by $19.5 \%$ for the high-mass envelope. Similarly, the amount of heating energy the air system needs to deliver to the spaces decreased by $74.7 \%$ and $78.3 \%$, respectively. The heating requirements are so low because the lights, fans, and equipment generate heat. Maximum cooling load was reduced by $26.4 \%$ for the improved envelope, and by $30.3 \%$ for the high-mass model. The maximum heating load was reduced by $46.2 \%$ for the improved envelope and by only $36.9 \%$ for the high-mass model. Results show that improved thermal comfort can be expected with improved thermal envelopes. For the office spaces, the high-mass model predictions indicate slightly less thermal comfort than the more conventional improved envelope model.

The results for the high-mass model show lower energy usage than those for the improved envelope model. This shows that exposing thermal mass offers good potential for improving the energy performance. However, because of the noise absorption provided by carpet, tiled floors may not be practical to implement in office spaces. The double concrete block walls may also be impractical. For these reasons, we dropped the high-mass option from the modeling exercise to reduce the number of cases 
in the study. However, results show that any design efforts that increase the exposure of thermal mass to the interior air space would be expected to result in energy savings.

\subsection{Daylighting with Skylights}

Section 5.2 presented results from modeling daylighting and lighting controls and adding skylights to the improved envelope. Allowing natural daylight to enter occupied spaces and turning off electric lights are important ways to save energy in commercial buildings. Results show that for the garage spaces, lighting electricity could be reduced by $62 \%$ and for the office spaces, by $41 \%$. The garages are lit using half of the design level during the night because they are partially occupied 24 hours a day. Similarly, the office areas ZN1 and ZN8 are 24-hour operations.

The reduced electric lighting results in significant cooling savings for office spaces because of the reduced heat gain. The model results show that the amount of cooling energy required by the offices decreased by $45.5 \%$ with the daylighting and improved thermal envelope. Heating loads and energy use for offices are increased somewhat compared to the improved envelope model, but remain lower than the baseline by $23.4 \%$ for load and $49.6 \%$ for energy. For the garage spaces, heat loads were reduced by just $0.3 \%$ and heating energy use actually increased by $5.5 \%$ because the electric lights do less heating. Results show that thermal comfort is not adversely affected by the design measures in the model compared to the baseline.

Results will depend on skylight glazing properties. Although skylights do a good job of bringing in a lot of daylight, they are often considered problematic because of the high heat gains during summer and glare problems. To counter this, the model used relatively high-performance glazing with a low SHGC of 0.175 and a $\mathrm{U}$-factor of $1.479\left(\mathrm{~W} / \mathrm{m}^{2} \cdot \mathrm{K}\right)$.

\subsection{Overhangs and Clerestories}

Section 5.3 presented modeling and results for altering the shape of the building's enclosure to provide overhangs on south-facing windows and adding sawtooth clerestories rather than skylights for daylighting. Results show that lighting savings were increased to $50.7 \%$ for the office spaces by carefully modeling the atrium to introduce daylight into ZN6 and ZN8, as well as into ZN5 and ZN7. Savings were somewhat less in the garage spaces, compared to the skylight model, at a $51.6 \%$ reduction.

The model results show that the amount of cooling energy the air system needs to deliver to the office spaces decreased by $55.0 \%$ with the north-facing clerestory and open atrium. Heating loads and energy use for office spaces are lower than the baseline by $23.9 \%$ for load and $43.9 \%$ for energy. For the garage spaces, the heating load was reduced by $2.5 \%$ and the heating energy by $1.6 \%$. The passive solar heating modestly reduces the heating requirements. Results show that thermal comfort is not adversely affected by the design measures in the model compared to the baseline.

\subsection{Ventilation}

Section 5.4 presented modeling and results for garage zones where the quantity of outdoor ventilation air was varied to simulate demand-controlled ventilation. Results indicate that significant energy could be saved if sensor-based, demand-controlled ventilation is implemented and pollutant production can be modeled. Model results showed a 78.3\% reduction in energy use and a 27.3\% reduction in load for the air system to control garage temperatures. Occupant thermal comfort is slightly degraded because the outdoor air provides helpful cooling in some situations.

\subsection{HVAC Systems}

Section 5.5 presented modeling and results for the improved building with detailed HVAC system models. These results allow energy use and cost implications of design improvements to be compared 
because the HVAC systems account for system efficiency and control situations. The Baseline Energy Model results are used for comparisons. Results for office zones are discussed first, followed by the garage zones.

\subsubsection{Office Zones}

Section 5.5.1 presented results for office zones cooled by rooftop-packaged DX systems in four stages.

The first stage attached the HVAC system used in the Baseline Energy Model to the improved building fabric, form, and operation developed in Section 5.3. The HVAC system was the same except that it had actual product COPs that were higher than the minimum COP specified in ASHRAE 90.1-2001(e). The improved building and realistic COP resulted in energy savings of $33.2 \%$ and energy cost savings of $33.5 \%$.

The second stage downsized the HVAC system because the original baseline system's capacity became excessive with the building improvements. The smaller HVAC systems reduced fan energy and cost by $42 \%$. In addition, the smaller systems reduced cooling electricity and raised heating energy (because fan heat is lowered). Overall, this step resulted in energy savings of $37.4 \%$ and energy cost savings of $44.1 \%$.

The third stage added HRVs that helped heating energy and hurt cooling energy. The cooling energy increases occur because the HRVs were operating during periods of free cooling when indoor air is warmer than outdoor air. This problem could be avoided in practice by bypassing the equipment during economizer cycles, but this could not be modeled. Overall, this step resulted in energy savings of 52.5\% and energy cost savings of $47.5 \%$.

The fourth stage changed the electric DX cooling equipment to higher efficiency units. This yielded energy savings of $59.2 \%$ and energy cost savings of $50.5 \%$.

In all cases, results show that thermal comfort in the office areas was improved compared to the baseline.

\subsubsection{Garage Zones}

Section 5.5.2 presented results for garage zones heated and ventilated by gas-fired unit ventilators in three stages.

The first stage attached the same HVAC system used in the Baseline Energy Model to the improved building fabric, form, and operation developed through Section 5.3. The improved building reduced energy use by $13.1 \%$ and energy cost by $26.4 \%$. The cost savings accrue from reduced lighting electricity and the passive solar design avoided increasing heating costs to offset the reduced heat from the lights.

The second stage was to reduce outdoor ventilation air by simulating a demand-controlled ventilation system. These results depend strongly on the modeling assumptions made in Section 5.4. Because ventilation requirements dominate the garage heating loads, reducing the outdoor air lowered heating energy by $84 \%$ and overall energy use by $63.6 \%$. Because natural gas is inexpensive, energy cost savings are not as high at $44.3 \%$.

The third stage was to add HRVs, a measure that was very effective at further reducing heating energy. Overall, this step resulted in garage space energy savings of $72.9 \%$ and energy cost savings of $48.3 \%$. The extremely low heating energy use shows that the building is being heated largely by fan energy. 
Results for fan energy did not change because the air systems were modeled as constant volume. Because air system flow rates in the garages are dictated by ventilation requirements, they do not decrease with improved design as they would if airflow rates were determined by heating and cooling needs. Fan energy should go down for the demand-controlled ventilation situation but it was not possible to model the fans as variable speed in EnergyPlus. This could be accomplished if EnergyPlus implemented a simple "flow" set point manager that works off a schedule.

Results for predictions of occupant thermal comfort in the garage spaces showed important effects of ventilation. The first-stage building improvements showed improved thermal comfort compared to the baseline. The demand-controlled ventilation scheme showed slightly poorer thermal comfort during hot weather because of reduced cooling from ventilation air. The HRV showed a significant shift in comfort where the spaces are generally warmer, increasing comfort in the winter and decreasing comfort in the summer. This highlights the need to bypass heat recovery equipment for garages in the summer.

\subsection{Photovoltaics}

Section 6.0 presented results for electricity production from solar electric systems. The results from the PVSyst model predicted total electricity production of $26.2 \mathrm{MWh}$ per year from a PV array rated at a 20$\mathrm{kW}$ peak production and tilted at $32^{\circ}$. If PV panels were flat, as for a roof-paver system, annual production would be about $11 \%$ lower. The facility electricity demand for the most efficient design modeled is $379 \mathrm{MWh}$ per year (including equipment), so such an array might provide as much as $6.9 \%$ of the electricity demand. This array would deploy $256 \mathrm{PV}$ modules with a total module surface area of about $165 \mathrm{~m}^{2}$. Attempting to generate the same amount of electricity as consumed by the energy efficient building would require about 15 such PV system(s) with a combined rated peak power of about $310 \mathrm{~kW}$. If the building were not as energy efficient and used the same electricity as the Baseline Energy Model, the $20.5-\mathrm{kW}$ PV system would generate $4.7 \%$ of the building's electricity. Attempting to generate the electricity consumed by the baseline building would require about 22 such systems to match consumption.

\subsection{Results Summary}

Tables 7-1 and 7-2 summarize the results for the entire building, combining the results for garages and offices. Previously, we had separated the results of the garage and office zones because of the differences between the two spaces. 
Table 7-1. Summary of Results for Energy Use for Entire Building

\begin{tabular}{|c|c|c|c|c|c|c|c|c|}
\hline & $\begin{array}{l}\text { Lights } \\
\text { (MWh/yr) }\end{array}$ & $\begin{array}{c}\text { Equipment } \\
\text { (MWh/yr) }\end{array}$ & $\begin{array}{c}\text { Fan } \\
\text { (MWh/yr) }\end{array}$ & $\begin{array}{c}\text { Cooling } \\
\text { (MWh/yr) }\end{array}$ & $\begin{array}{l}\text { Heating } \\
\text { (gas; } \\
\text { MWh/yr) }\end{array}$ & $\begin{array}{l}\text { Total w/o } \\
\text { equipment } \\
\text { (MWh/yr) }\end{array}$ & $\begin{array}{c}\text { Intensity } \\
\left(\mathrm{kWh} / \mathrm{m}^{2} \cdot \mathrm{yr}\right)\end{array}$ & $\begin{array}{c}\text { Intensity } \\
\left(k B T U / \mathrm{ft}^{2} \cdot \mathrm{yr}\right)\end{array}$ \\
\hline $\begin{array}{l}\text { BASELINE } \\
\text { AVERAGE } \\
\text { IMPROVED } \\
\text { BUILDING }\end{array}$ & 251 & 119 & 140 & 51 & 407 & 849 & 245 & 77.7 \\
\hline $\begin{array}{l}\text { OVERSIZED } \\
\text { DX } \\
\text { PRESCRIPTIVE } \\
\text { VENT } \\
\text { DOWNSIZED }\end{array}$ & 123 & 119 & 140 & 33 & 378 & 674 & 195 & 61.8 \\
\hline $\begin{array}{l}\text { DX } \\
\text { DEMAND- } \\
\text { VENT } \\
\text { HIGH- } \\
\text { EFFICIENCY }\end{array}$ & 123 & 119 & 114 & 30 & 125 & 392 & 113 & 35.8 \\
\hline $\begin{array}{l}\text { DX } \\
\text { HEAT } \\
\text { RECOVERY }\end{array}$ & 123 & 119 & 114 & 23 & 14 & 274 & 79 & 25.0 \\
\hline
\end{tabular}

Table 7-2. Summary of Results for Energy Cost for Entire Building

\begin{tabular}{|c|c|c|c|c|c|c|c|c|}
\hline & $\begin{array}{c}\text { Lights } \\
\text { (\$/yr) }\end{array}$ & $\begin{array}{l}\text { Equipment } \\
(\$ / y r)\end{array}$ & $\begin{array}{l}\text { Fans } \\
\text { (\$/yr) }\end{array}$ & $\begin{array}{c}\text { Cooling } \\
\text { (\$/yr) }\end{array}$ & $\begin{array}{l}\text { Heat } \\
\text { (gas; } \\
\text { \$/yr) } \\
\end{array}$ & $\begin{array}{c}\text { Total w/o } \\
\text { equipment } \\
(\$ / y r)\end{array}$ & $\begin{array}{l}\text { Intensity } \\
\left(\$ / \mathrm{m}^{2} \cdot \mathrm{yr}\right)\end{array}$ & $\begin{array}{r}\text { Intensity } \\
\left(\$ / \mathrm{ft}^{2} \cdot \mathrm{yr}\right)\end{array}$ \\
\hline $\begin{array}{l}\text { BASELINE } \\
\text { AVERAGE } \\
\text { IMPROVED } \\
\text { BUIING }\end{array}$ & 42,030 & 19,962 & 23,095 & 8,908 & 12,517 & 86,550 & 25.0 & 2.32 \\
\hline $\begin{array}{l}\text { BUILDING } \\
\text { OVERSIZED DX } \\
\text { PRESCRIPTIVE } \\
\text { VENT }\end{array}$ & 20,087 & 19,962 & 23,095 & 5,821 & 11,632 & $\begin{array}{l}60,635 \\
(-29.9 \%)\end{array}$ & 17.5 & 1.63 \\
\hline $\begin{array}{l}\text { DOWNSIZED DX } \\
\text { DEMAND-VENT }\end{array}$ & 20,087 & 19,962 & 18,857 & 5,185 & 4,048 & $\begin{array}{l}48,177 \\
(-44.3 \%)\end{array}$ & 13.9 & 1.29 \\
\hline $\begin{array}{l}\text { HIGH-EFFICIENCY } \\
\text { DX } \\
\text { HEAT RECOVERY }\end{array}$ & 20,087 & 19,962 & 18,722 & 4,069 & 863 & $\begin{array}{l}43,741 \\
(-49.5 \%)\end{array}$ & 12.7 & 1.18 \\
\hline
\end{tabular}

The modeling results indicate that, compared to a building that is barely in compliance with code, incorporating all the design measures evaluated can reduce energy costs by $\$ 42,809 / \mathrm{yr}$, or a savings of about $50 \%$. This goal could be exceeded by reducing fan energy through variable speed drives with VAV air systems, passive ventilation of garage spaces, or both. The overall energy use on an area basis could be decreased from a baseline intensity of $245 \mathrm{kWh} / \mathrm{m}^{2} \cdot \mathrm{yr}\left(77.7 \mathrm{kBtu} / \mathrm{ft}^{2} \cdot \mathrm{yr}\right)$ to $79 \mathrm{kWh} / \mathrm{m}^{2} \cdot \mathrm{yr}(25$ $\left.\mathrm{kBtu} / \mathrm{ft}^{2} \cdot \mathrm{yr}\right)$. Energy cost intensity could be reduced from $\$ 25.0 / \mathrm{m}^{2} \cdot \mathrm{yr}\left(\$ 2.32 / \mathrm{ft}^{2} \cdot \mathrm{yr}\right)$ to $12.7 \$ / \mathrm{m}^{2} \cdot \mathrm{yr}(1.18$ $\left.\$ / \mathrm{ft}^{2} \cdot \mathrm{yr}\right)$. 


\subsection{Design Recommendations}

Based on the Stage One schematics of December 14, 2001, and the results of modeling presented in this report, we can make the design recommendations outlined in the sections that follow.

\subsection{Floor Plan Issues}

One important aspect of designing for good utilization of daylight is to identify spaces that do not always need light and locate them deep inside the building plan, reserving perimeter areas for spaces that can benefit from availability of daylight. Because perimeter and atria areas are easier to daylight, spaces that need only intermittent light, such as storage rooms, should be placed away from these areas where daylight is plentiful. For the proposed Teterboro Airport building, rooms along the south side designated for oil storage, tool storage, and as the mechanic's tool room should be moved inward and replaced with shop spaces, such as the carpenter's shop. On the first floor, in the northeast, rooms designated as pantry and toilet should be moved inward and replaced with office type space. Similarly, in the customs area in the southwest corner of the building, there is a large storage room that should be moved inward (unless there is a programmatic reason for the contents to be visible).

\subsection{Building Envelope Issues}

Insulation levels recommended by the architect appear adequate and should help to reduce energy use and improve thermal comfort. Higher levels of insulation are not warranted, but increasing the amount of thermal mass exposed to interior air should be encouraged. This can be accomplished by using floor coverings with high thermal conductivity, by moving insulation outward, and by locating massive components of walls next to occupied spaces.

For glazing, we recommend using at least low-e dual-pane insulated glazing units. Airport noise concerns alone necessitate dual glazing (triple-layer glazing would be even better). The architect's selection of Viracon's Azurlite ${ }^{\mathrm{TM}}$ is good as long as this outer glazing is used with a low-e coating applied and assembled into insulated glazing units (IGUs). For noise abatement, IGUs with different thickness glazing layers on the inside and outside and heavy gas fills could be used. The glazing modeled for the improved envelope used argon gas fill and low-e coatings on surface 2. Well-insulating frames (e.g., thermally broken) should be used and warm-edge glazing systems considered. Once these design details are available, energy models should be updated to include the thermal performance of the window frame and edge of glass regions.

\subsection{Daylighting Issues}

Daylighting results showed that reducing electric lighting yields significant energy savings $(\$ 11,750 / \mathrm{yr}$ in the garage zones and $\$ 10,193 / \mathrm{yr}$ in the office zones). This level of daylighting is very aggressive and achieving this level of savings will require a concerted effort. Adding architectural elements such as atria, skylights, translucent panels, and clerestories is the first step. The next step is to design open and shallow floor plans so that light can move into and across zones. Furniture and interior finishes need to be carefully selected and situated to facilitate light penetration and reflection. The design team responsible for the interior must be apprised of the unique needs for daylighting. Daylight sensors need to be carefully selected, placed, and calibrated. Lighting controls need to be carefully specified, commissioned, and programmed so as to actually dim or turn off lights when sufficient natural daylight is available. This will require additional commissioning costs and visits at different times of the year. Additional modeling 
and analysis of daylighting should be performed using the appropriate computer programs once design details are available for interior floor plan, furniture, and finishes.

If skylights are used, care should be taken to use highly shading, low-SHGC glazing systems. Once designs are available and glazing units selected, additional energy simulations should be performed to understand how cooling loads are affected. The glazing configurations modeled may or may not be available in practice because of a need for tempered glass in skylights. Moving the low-e coating to surface 3 or using suspended film products rather than not using a low-e coating should be considered. Although view glazing may be appropriate for an airport situation, designers should also consider using translucent/diffuse panel systems based on glass fiber reinforced plastic in garage and shop areas for highquality daylight with minimal glare and heat gain problems. However, EnergyPlus cannot model translucent panel systems well because glazing systems with translucent mass insulation in "gaps" are not covered by the window algorithms (nor are they calculable using the Window 5 computer program).

Because most product lines have standardized on low-SHGC glazing, high-SHGC windows for clerestories might be more difficult to obtain and custom-built glazing may be required. Designers should not necessarily expect to be able to obtain the two different types of glazing (high- and low-SHGC) with matching visual appearance and color.

\subsection{HVAC System Design}

The design analysis presented in this report focused on rooftop-packaged systems using DX cooling and gas-fired heating. We modeled these systems because they are common in small commercial buildings and offer advantages in terms of construction scheduling and simplicity of control and maintenance. Centralized HVAC systems with water-based cooling and heating are also worth considering, but time did not allow developing EnergyPlus models of these systems. The high groundwater at the Teterboro Airport location may make using GSHPs rather than air-cooled DX equipment attractive. As HVAC equipment specifications are developed, additional building energy modeling should be performed. HRV systems should be considered to save heating energy but should generally be bypassed during the cooling season. An enthalpy heat recovery system may be useful for office spaces, but our modeling evaluated only sensible heat recovery.

Further reductions in energy use and cost could be obtained by reducing fan electricity. This can be accomplished in two ways - with VAV air systems and with passive/natural ventilation. The HVAC models presented here were constant-volume air systems. Despite considerable effort, using EnergyPlus to model VAV air systems proved unsuccessful for the single-package DX and ventilator/heater systems. However, such systems are available.

Because processes conducted in the garage spaces would be expected to create pollution, ventilating these spaces is very important for ensuring a healthy indoor environment. Using variable speed drives for ventilation fans in the garage spaces is especially attractive for use with demand-controlled ventilation. A passive ventilation strategy should be considered for the garage spaces where the large garage doors in these spaces are simply left open rather than running air system fans. The annual weather data used for modeling indicates that the outdoor dry bulb is above the heating set point of $10^{\circ} \mathrm{C}\left(50^{\circ} \mathrm{F}\right)$ for about $57 \%$ of the hours in the year. Operating the air system for heating, then, would be unnecessary much of the time. Once designs are finalized for garage and shop spaces and their access doors, additional modeling using a multizone airflow program should be performed to predict air change rates for passive ventilation schemes. If air change rates are high enough with natural movement of outdoor air through large doorways, considerable fan energy could be saved by not running the main supply and/or return fans. Real-time sensors for measuring IAQ are important for both passive and demand-controlled ventilation schemes. Designers should consider deploying IAQ sensors for $\mathrm{CO}_{2}$, carbon monoxide, volatile organic 
compounds, and particulates in the garage and shop spaces. Sensors should be carefully selected and integrated with the building energy monitoring and control system. Provisions should be made for additional commissioning and long-term maintenance of IAQ monitoring equipment. Localized exhaust systems should be installed where specific pollution sources are located (e.g., near vehicle tailpipes, paint booths, and wood saws). For office spaces, at least $\mathrm{CO}_{2}$ sensors should be deployed to ensure that sufficient quantities of outdoor air are being introduced. 


\subsection{Conclusions and Future Research}

In this section, we present general conclusions and discuss potential future research topics.

\subsection{General Conclusions}

Conducting the design analysis exercise described in this report led to the following general conclusions:

- The goal of reducing energy cost in small commercial buildings by $50 \%$ compared to ASHRAE 90.1-2001(e) is attainable in a climate typical of the East Coast of the United States.

- Proposed Addendum (e) for ASHRAE Energy Standard 90.1-2001 is useful for calculating baseline energy use for determining energy savings.

- EnergyPlus has been developed to the point where it can be used to analyze building energy design for some, but not all, HVAC systems.

- The versatile capabilities of EnergyPlus for specifying schedules facilitate modeling demandcontrolled ventilation schemes.

\subsection{Future Research}

We have identified additional research and analysis opportunities as outlined in this section. In some cases, we attempted modeling with EnergyPlus that was unsuccessful either because of input errors or program problems. In other cases, modeling would probably have succeeded with sufficient time to fully develop model input and document new methods. Other types of modeling require that the building design and usage characteristics be more fully known.

- As designs evolve for the Teterboro Airport building, energy models should be continually updated to ensure that the impact on energy efficiency is understood.

- As designs evolve for interior layout, furniture, and finishes, accurate daylighting models should be developed to predict levels and quality of natural lighting, to assist in properly locating daylight sensors, and to better estimate the fraction of lighting that can be replaced with daylight.

- Many efforts to model VAV HVAC systems in EnergyPlus were unsuccessful. Further efforts to model VAV packaged systems are warranted for the Teterboro project because of the potential to reduce high fan energy and costs. EnergyPlus appears to be able to model a VAV system only for centralized, chilled-water-based HVAC systems. Demand-ventilation schemes could be modeled with VAV if EnergyPlus's set point managers were extended to allow setting flow variables.

- Modeling a centralized GSHP is warranted for the Teterboro Airport building. Although initial results appeared promising, we abandoned GSHP modeling after considerable effort because of controlling difficulties and limited time availability. 
- We attempted nighttime ventilation precooling modeling using EnergyPlus schedules for outdoor air ventilation. Although initial results appeared promising, this was abandoned because of limited availability of time.

- Passive ventilation of the garage and shop spaces may be possible by leaving garage doors open. This mode of building operation could save considerable fan power by switching off ventilation fans. Airflow models of the type known as multi-zone could be developed. Developing an EnergyPlus model that uses the multi-zone air-modeling link to predict air changes would also allow modeling space thermal conditions.

- HRV equipment, when modeled, is currently on all the time. Implementing EnergyPlus modeling of lockout/bypassing is needed because the heat recovery is detrimental during free-cooling modes. 


\section{References}

ASHRAE. 1999. ASHRAE Standard 62-1999, Ventilation for Acceptable Indoor Air Quality. Atlanta, GA: ASHRAE.

ASHRAE. 2001. ASHRAE Standard 90.1-2001, Energy Standard for Buildings Except Low-Rise Residential Buildings. Atlanta, GA: ASHRAE.

ASHRAE. 2002. Addendum 90.1 (e), ASHRAE Standard 90.1-2001, Energy Standard for Buildings Except Low-Rise Residential Buildings. Submitted for public review July 2002. Atlanta, GA: ASHRAE.

BP Solar. 2001. "BP 585F 85-Watt High-Efficiency Monocrystalline PV Module” (product data sheet). Linthicum, MD: BP Solar International LLC. Available on line at http://www.bpsolar.com/pdf/BP 585F Data Sheet.pdf.

Carrier Corporation. 2002. "Product Data 48TM004-028 48HJ004-017 Single-Package Rooftop Units Gas Heating/Electric Cooling ASHRAE 90.1 Compliant.” Syracuse, NY: Carrier Corporation.

Crawley, D.B., L.K. Lawrie, F.C. Winkelmann, W.F. Buhl, Y.J. Huang, C.O. Pedersen, R.K. Strand, R.J. Liesen, D.E. Fisher, M.J. Witte, and J. Glazer. 2001. "EnergyPlus: Creating a New-Generation Building Energy Simulation Program.” Energy and Buildings 33(2001): 319-331.

Fanger, P.O. 1982. Thermal Comfort. Malabar, FL: Robert E Krieger Publishing Company.

Hayter, S.J., P.A. Torcellini, R. Judkoff, R.C. Snead, and R.B. Hayter. 2000. “Designing for Sustainability.” NREL/CP-550-27797. Golden, CO: NREL.

Henninger, R.H., and M.J. Witte. 2001. EnergyPlus Testing with ANSI/ASHRAE Standard 140-2001 (BESTEST). Park Ridge, IL: Gard Analytics.

Marion, W., and S. Wilcox. 1995. Solar Radiation Data Manual for Buildings. Golden, CO: NREL.

Mermond, A. 2002. PVSYST V 3.2. CUEPE. University of Geneva, Switzerland. Available on line at http://www.unige.ch/cuepe/pvsyst/pvsyst/index.htm.

Neymark, J., and R. Judkoff. 2002. International Energy Agency Building Energy Simulation Test and Diagnostic Method for Heating, Ventilating, and Air-conditioning Equipment Models (HVAC BESTEST) Volume 1: Cases E100-E200. Golden, CO: NREL.

Winkelmann, F.C., B.E. Birdsall, W.F. Buhl, K.L Ellington, A.E. Erdem, J.J. Hirsch, and S. Gates. 1993. DOE-2 BDL Summary Version 2.1E. LBNL-34946. Berkeley, CA: Lawrence Berkeley National Laboratory.

Wolfram Research. 1999. Mathematica 4.0. Champaign, IL: Wolfram Research, Inc. 


\section{Appendix A. Predesign Program Summary}

\section{Table A-1. Administration/ARFF Building Program}

\begin{tabular}{|c|c|c|c|c|c|c|c|c|c|c|c|c|}
\hline Department & Division & Space Use & Type & Sqft & $\begin{array}{l}\text { Circ. } \\
\text { Sqft }\end{array}$ & $\begin{array}{c}\text { Heating } \\
(\operatorname{deg} F)\end{array}$ & $\begin{array}{l}\text { Cooling } \\
(\operatorname{deg} \text { F) }\end{array}$ & Ventilation & $\begin{array}{l}\text { Occupancy } \\
\text { Schedule }\end{array}$ & $\begin{array}{c}\text { No. of } \\
\text { people* }\end{array}$ & $\begin{array}{c}\text { Day- } \\
\text { lighting }\end{array}$ & Special Requirements \\
\hline \multirow[t]{4}{*}{ Common } & & Vestibule & & 150 & 195 & 70 & 75 & $15 \mathrm{cfm} /$ person & & & yes & "front façade w/exterior visibility, two story \\
\hline & & Lobby & & 400 & 520 & 70 & 75 & $15 \mathrm{cfm} /$ person & & & yes & display lighting, two story \\
\hline & & Core & & 1200 & 1560 & 70 & 75 & $15 \mathrm{cfm} /$ person & & & no & \\
\hline & & & & 1,750 & 2,275 & & & & & & & \\
\hline \multirow[t]{17}{*}{ Adminstration } & PA admin & Office & enclosed & 270 & 351 & 70 & 75 & $15 \mathrm{cfm} /$ person & $8: 00-5: 00$ & 1 & yes & view of tarmac \\
\hline & & Office & enclosed & 195 & 254 & 70 & 75 & $15 \mathrm{cfm} /$ person & $8: 00-5: 00$ & 1 & yes & \\
\hline & & Office & open & 80 & 104 & 70 & 75 & $15 \mathrm{cfm} /$ person & $8: 00-5: 00$ & 1 & yes & \\
\hline & & Office & open & 120 & 156 & 70 & 75 & $15 \mathrm{cfm} /$ person & $8: 00-5: 00$ & 6 & yes & \\
\hline & & Office & enclosed & 650 & 845 & 70 & 75 & $15 \mathrm{cfm} /$ person & $8: 00-5: 00$ & 50 & yes & \\
\hline & & Conference & & 195 & 254 & 70 & 75 & $15 \mathrm{cfm} /$ person & $8: 00$ - 5:00 & 10 & yes & \\
\hline & & File & active & 80 & 104 & 70 & 75 & $15 \mathrm{cfm} /$ person & $8: 00-5: 00$ & & no & \\
\hline & & Office & future & 120 & 156 & 70 & 75 & $15 \mathrm{cfm} /$ person & $8: 00-5: 00$ & 1 & yes & \\
\hline & & Office & future & 64 & 83 & 70 & 75 & $15 \mathrm{cfm} /$ person & $8: 00-5: 00$ & 1 & yes & \\
\hline & Air. Serv./PM & Office & enclosed & 195 & 254 & 70 & 75 & $15 \mathrm{cfm} /$ person & $8: 00-5: 00$ & 1 & yes & view of tarmac \\
\hline & & Office & enclosed & 0 & 0 & 70 & 75 & $15 \mathrm{cfm} /$ person & $8: 00-5: 00$ & 1 & yes & \\
\hline & & Office & open & 80 & 104 & 70 & 75 & $15 \mathrm{cfm} /$ person & $8: 00$ - 5:00 & 1 & yes & \\
\hline & & Office & open & 64 & 83 & 70 & 75 & $15 \mathrm{cfm} /$ person & $8: 00-5: 00$ & 4 & yes & \\
\hline & & File & active & 48 & 62 & 70 & 75 & $15 \mathrm{cfm} /$ person & $8: 00-5: 00$ & & no & \\
\hline & & Office & enclosed & 108 & 140 & 70 & 75 & $15 \mathrm{cfm} /$ person & $8: 00-5: 00$ & & yes & \\
\hline & & Kitchen & & 63 & 82 & 70 & 75 & demand exh. & $8: 00-5: 00$ & & no & \\
\hline & & File & inactive & 400 & 520 & 70 & 75 & $15 \mathrm{cfm} /$ person & $8: 00-5: 00$ & & no & \\
\hline
\end{tabular}




\begin{tabular}{|c|c|c|c|c|c|c|c|c|c|c|c|c|}
\hline \multicolumn{13}{|c|}{ Table A-1. Administration/ARFF Building- } \\
\hline \multicolumn{13}{|c|}{ Teterboro Airport } \\
\hline \multirow[t]{10}{*}{ Department } & Division & Space Use & Type & Sqft & $\begin{array}{l}\text { Circ. } \\
\text { Sqft }\end{array}$ & $\begin{array}{r}\text { Heating } \\
\text { (deg F) }\end{array}$ & $\begin{array}{r}\text { Cooling } \\
\text { (deg F) }\end{array}$ & Ventilation & $\begin{array}{c}\text { Occupancy } \\
\text { Schedule }\end{array}$ & $\begin{array}{c}\begin{array}{c}\text { No. of } \\
\text { people* }\end{array} \\
\end{array}$ & $\begin{array}{c}\text { Day- } \\
\text { lighting }\end{array}$ & Special Requirements \\
\hline & Air. Fac. & Office & enclosed & 80 & 104 & 70 & 75 & $15 \mathrm{cfm} /$ person & $8: 00-5: 00$ & 1 & yes & \\
\hline & & Office & 6 engineers & 480 & 624 & 70 & 75 & $15 \mathrm{cfm} /$ person & $8: 00-5: 00$ & 6 & yes & \\
\hline & & Conference & & 192 & 250 & 70 & 75 & $15 \mathrm{cfm} /$ person & $8: 00-5: 00$ & & yes & \\
\hline & Prop. Dev. & Office & enclosed & 80 & 104 & 70 & 75 & $15 \mathrm{cfm} /$ person & $8: 00-5: 00$ & 1 & yes & \\
\hline & Oper./ARFF & Office & enclosed & 165 & 215 & 70 & 75 & $15 \mathrm{cfm} /$ person & $8: 00-5: 00$ & 1 & yes & \\
\hline & & Office & enclosed & 120 & 156 & 70 & 75 & $15 \mathrm{cfm} /$ person & $8: 00-5: 00$ & 1 & yes & \\
\hline & & File & active & 48 & 62 & 70 & 75 & $15 \mathrm{cfm} /$ person & $8: 00-5: 00$ & & no & \\
\hline & Maint. & Office & enclosed & 165 & 215 & 70 & 75 & $15 \mathrm{cfm} /$ person & $8: 00-5: 00$ & 1 & yes & \\
\hline & & & & 1,330 & 1,729 & & & & & & & \\
\hline \multirow{18}{*}{ Operations/ARFF } & & & & & & & & & & & & \\
\hline & & Office & enclosed & 320 & 416 & 70 & 75 & $15 \mathrm{cfm} /$ person & $24 \mathrm{hr}$ & 4 & yes & \\
\hline & & Office & enclosed & 320 & 416 & 70 & 75 & $15 \mathrm{cfm} /$ person & $24 \mathrm{hr}$ & 4 & yes & \\
\hline & & Office & open & 400 & 520 & 70 & 75 & $15 \mathrm{cfm} /$ person & $24 \mathrm{hr}$ & 10 & yes & \\
\hline & & Green House & & 200 & 260 & 70 & 75 & $15 \mathrm{cfm} /$ person & $24 \mathrm{hr}$ & 5 & yes & view of runway/no glare \\
\hline & & Conference & & 240 & 312 & 70 & 75 & $15 \mathrm{cfm} /$ person & $24 \mathrm{hr}$ & 15 & yes & \\
\hline & & File & active & 60 & 78 & 70 & 75 & $15 \mathrm{cfm} /$ person & $24 \mathrm{hr}$ & & no & \\
\hline & & Lounge & & 180 & 234 & 70 & 75 & $15 \mathrm{cfm} /$ person & $24 \mathrm{hr}$ & & yes & \\
\hline & & Restrooms & shower/locker & 1200 & 1560 & 70 & 75 & $24 \mathrm{hr}$. exhaust & $24 \mathrm{hr}$ & & no & \\
\hline & & Kitchen & & 156 & 203 & 70 & 75 & demand exh. & $24 \mathrm{hr}$ & & no & \\
\hline & & Vending & vending/recyc. & 60 & 78 & 70 & 75 & $15 \mathrm{cfm} /$ person & $24 \mathrm{hr}$ & & no & overhead clearance req. ( 7 ' above truck) \\
\hline & & Garage & & 2250 & 2925 & 70 & 75 & vehicle exhaus: & $24 \mathrm{hr}$ & & yes & \\
\hline & & & air tank fill & 100 & 130 & 50 & none & $15 \mathrm{cfm} /$ person & $24 \mathrm{hr}$ & & no & \\
\hline & & & eye wash/shwr & 100 & 130 & 70 & 75 & $15 \mathrm{cfm} /$ person & $24 \mathrm{hr}$ & & no & temperature control \\
\hline & & & canine shelter & 150 & 195 & none & none & demand exh. & $24 \mathrm{hr}$ & 1 canine & no & \\
\hline & & & wildlife storage & 24 & 31 & none & none & demand exh. & $24 \mathrm{hr}$ & & no & \\
\hline & & & & 5,760 & 7,488 & & & & & & & \\
\hline & & & & & & & & & & & & \\
\hline
\end{tabular}


Table A-1. Administration/ARFF Building-

\begin{tabular}{|c|c|c|c|c|c|c|c|c|c|c|c|c|}
\hline \multicolumn{13}{|c|}{ Table A-1. Administration/ARFF Building- } \\
\hline \multicolumn{13}{|c|}{ Teterboro Airport } \\
\hline & & & & & & & & & & & & \\
\hline Department & Division & Space Use & Type & Sqft & $\begin{array}{l}\text { Circ. } \\
\text { Sqft }\end{array}$ & $\begin{array}{l}\text { Heating } \\
\text { (deg F) }\end{array}$ & $\begin{array}{l}\text { Cooling } \\
\text { (deg F) }\end{array}$ & Ventilation & $\begin{array}{c}\text { Occupancy } \\
\text { Schedule } \\
\end{array}$ & $\begin{array}{c}\begin{array}{c}\text { No. of } \\
\text { people* }^{*}\end{array} \\
\end{array}$ & $\begin{array}{c}\begin{array}{c}\text { Day- } \\
\text { lighting }\end{array} \\
\end{array}$ & Special Requirements \\
\hline \multirow[t]{16}{*}{ Maintenance } & & Office & lead mech. & 80 & 104 & 70 & 75 & $15 \mathrm{cfm} /$ persor & $8: 00-5: 00$ & $\begin{array}{ll}\quad 1 \\
\end{array}$ & yes & \\
\hline & & Shop & maintenance & 9500 & 12350 & 65 & none & vehicle exhaus: & $24 \mathrm{hr}$ & 6 & yes & \\
\hline & & Shop & carpenter & 468 & 608 & 65 & none & $15 \mathrm{cfm} /$ person & $24 \mathrm{hr}$ & & yes & equipment may require additional ventilatior \\
\hline & & Shop & electrical & 320 & 416 & 65 & none & $15 \mathrm{cfm} /$ person & $24 \mathrm{hr}$ & & yes & \\
\hline & & Office & work station & 36 & 47 & 70 & 75 & $15 \mathrm{cfm} /$ person & $24 \mathrm{hr}$ & & yes & \\
\hline & & Kitchen & lounge & 195 & 254 & 70 & 75 & demand exh. & $24 \mathrm{hr}$ & & no & \\
\hline & & Restrooms & shower/locker & 432 & 562 & 70 & 75 & $24 \mathrm{hr}$. exhaust & $24 \mathrm{hr}$ & & no & \\
\hline & & Shop & mech. tools & 272 & 354 & 65 & none & $15 \mathrm{cfm} /$ person & $24 \mathrm{hr}$ & & no & \\
\hline & & Storage & bulk/tools & 272 & 354 & 50 & none & $15 \mathrm{cfm} /$ person & $24 \mathrm{hr}$ & & no & \\
\hline & & Storage & oil & 98 & 127 & 50 & none & none & & & no & \\
\hline & & Storage & tool & 221 & 287 & 50 & none & none & & & no & \\
\hline & & Storage & plumb./elec. & 221 & 287 & 50 & none & none & & & no & \\
\hline & & Shop & paint & 240 & 312 & 50 & none & none & & & no & \\
\hline & & Storage & ext. vehicle & 200 & & none & none & none & & & yes & \\
\hline & & Storage & sand/chemical & 2704 & & none & none & none & & & yes & \\
\hline & & & & 15,259 & 16,062 & & & & & & & \\
\hline & & & & & & & & & & & & \\
\hline \multirow[t]{6}{*}{ Noise Abatement } & & Office & enclosed & 120 & 156 & 70 & 75 & $15 \mathrm{cfm} /$ person & $8: 00-5: 00$ & 1 & yes & \\
\hline & & Office & enclosed & 80 & 104 & 70 & 75 & $15 \mathrm{cfm} /$ person & $8: 00-5: 00$ & 1 & yes & \\
\hline & & Office & open & 384 & 499 & 70 & 75 & $15 \mathrm{cfm} /$ person & $24 \mathrm{hr}$ & 6 & yes & \\
\hline & & Office & open & 288 & 374 & 70 & 75 & $15 \mathrm{cfm} /$ person & $8: 00-5: 00$ & & yes & 9' ceiling \\
\hline & & File & & 30 & 39 & 70 & 75 & $15 \mathrm{cfm} /$ person & $8: 00-5: 00$ & & no & \\
\hline & & & & 902 & 1,173 & & & & & & & \\
\hline
\end{tabular}




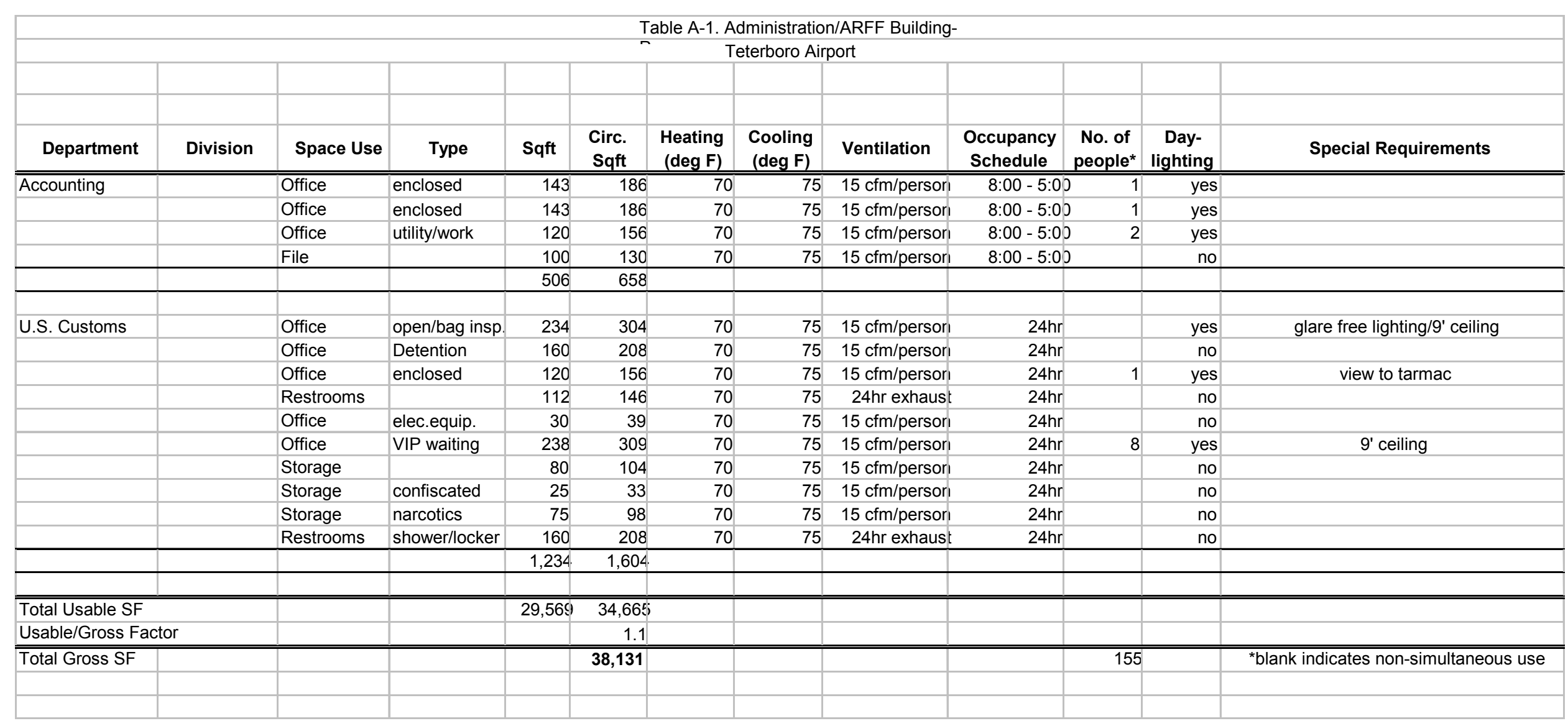


Appendix B. Outdoor Temperature Histogram

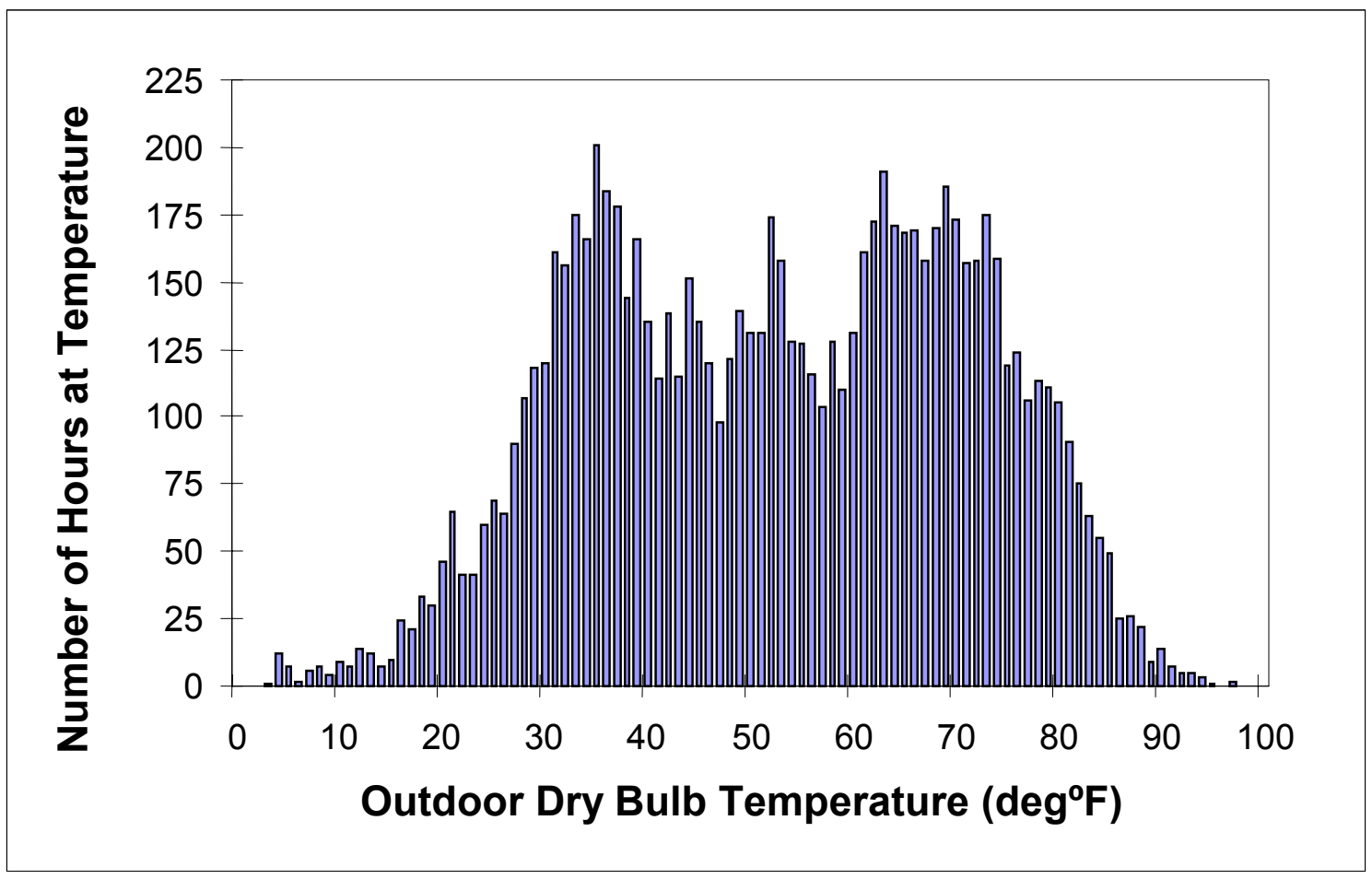

Figure B-1. Typical year outdoor temperature histogram 


\section{Appendix C. EnergyPlus Input Files}

Selected input files used to generate the final results presented in this report are listed in Table C-1. These EnergyPlus computer files are available from the authors of this report.

Table C-1. Selected EnergyPlus Input Files Available from Modeling Effort

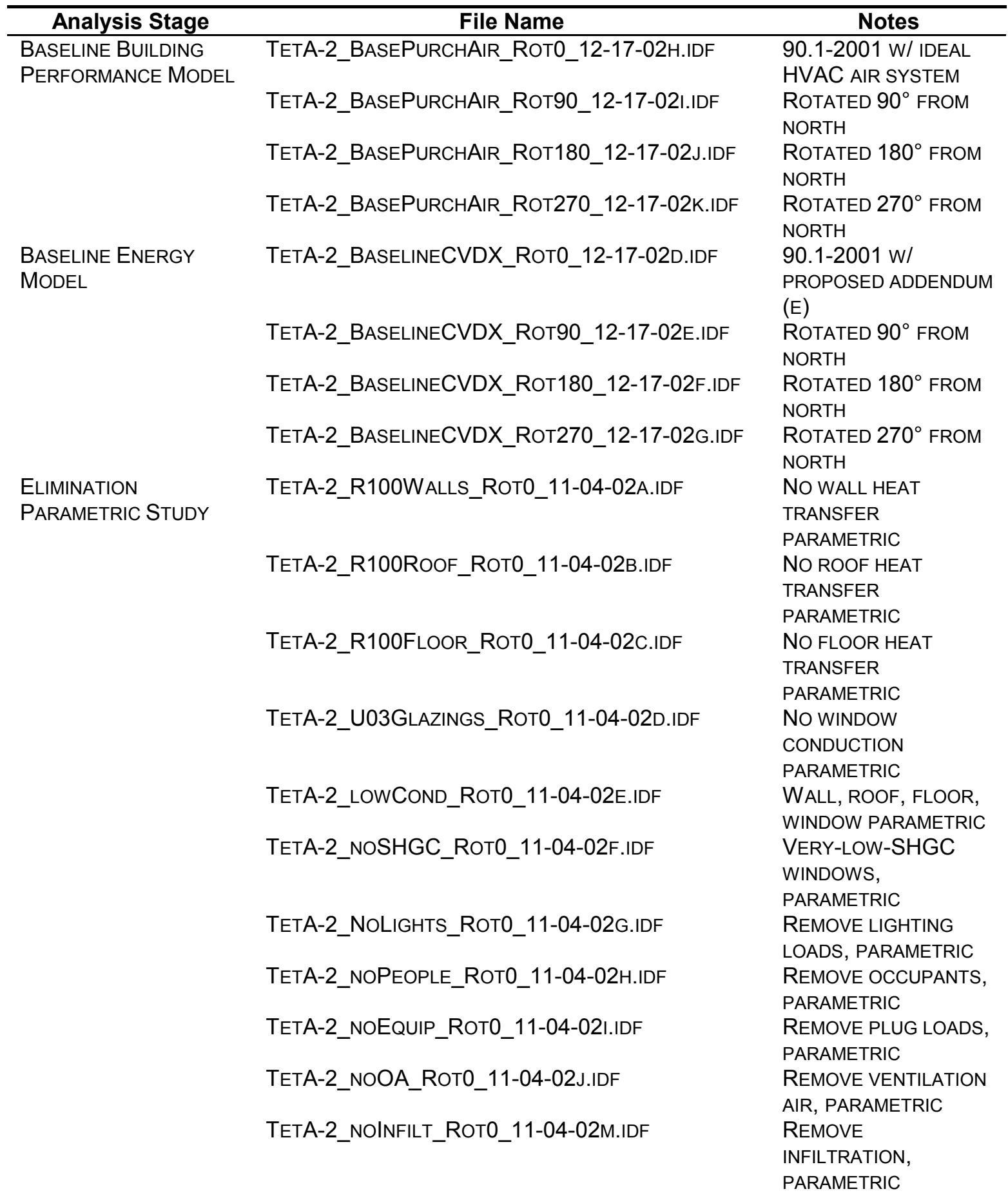




\begin{tabular}{|c|c|c|}
\hline ENVELOPE & TETA-2_PURCHAIR_ENVEL_AZURLITE_ROT0_12- & \\
\hline IMPROVEMENTS & 17-02L.IDF & \\
\hline HIGH-MASS ENVELOPE & TETA- & \\
\hline IMPROVEMENTS & $\begin{array}{l}\text { 2_PURCHAIR_HIMASSENVEL_AZURLITE_ROT0_12- } \\
\text { 17-02P.IDF }\end{array}$ & \\
\hline DAYLIGHTING WITH & TETA-2 SKYLIGHTSPURCHAIR ROT0 12-17- & \\
\hline SKYLIGHTS & 02M.IDF & \\
\hline DAYLIGHTING WITH & TET_OVERHNG_CLERE_PURCHAIR_ROT0_12-17- & \\
\hline OVERHANGS AND & 020.IDF & \\
\hline \multicolumn{3}{|l|}{ CLERESTORIES } \\
\hline DEMAND-CONTROLLED & TET_DEMANDVENT_PURCHAIR_ROT0_12-17- & \\
\hline VENTILATION & 02N.IDF & \\
\hline NIGHT OA & (ABORTED) & \\
\hline \multicolumn{3}{|l|}{ PRECOOLING } \\
\hline OVERSIZED DX & TET_DEMANDVENT_CVDX_ROT0_12-17-02Q.IDF * & OFFICE STAGE 1 \\
\hline DOWNSIZED DX & $\begin{array}{l}\text { TET_DMNDVENT_CVDX_DOWNSIZED_ROT0_12- } \\
\text { 17-02R.IDF }\end{array}$ & OFFICE STAGE 2 \\
\hline DOWNSIZED DX + HRV & $\begin{array}{l}\text { TET_DMNDVENT_CVDX_HRV_ROT0_12-17- } \\
02 \text { S.IDF }^{\star}\end{array}$ & OFFICE STAGE 3 \\
\hline $\begin{array}{l}\text { HIGH EFFICIENCY DX + } \\
\text { HRV }\end{array}$ & $\begin{array}{l}\text { TET_DMNDVENT_CVDX_HRV_HIEFFIC_ROT0_12- } \\
\text { 17-02T.IDF * }\end{array}$ & OfFICE STAGE 4 \\
\hline $\begin{array}{l}\text { PRESCRIPTIVE } \\
\text { MINIMUM VENTILATION }\end{array}$ & $\begin{array}{l}\text { TET_FIXEDVENT_CVDX_HRV_EIEFFIC_ROT0_12- } \\
\text { 18-02C.IDF }\end{array}$ & GARAGE STAGE 1 \\
\hline DEMAND-CONTROLLED & TET_VAVGARAGE_CVDX-HRV_HIEFFIC- & GARAGE STAGE 2, \\
\hline VENTILATION & ROT0_12-20-02A.IDF & NOT REALLY VAV \\
\hline $\begin{array}{l}\text { DEMAND-CONTROLLED } \\
\text { VENTILATION + HRV }\end{array}$ & TET_V̄AVGARAGE+HRV_ROT0_12-20-02D.IDF & $\begin{array}{l}\text { GARAGE STAGE } 3 \text {, } \\
\text { NOT REALLY VAV }\end{array}$ \\
\hline RENEWABLE & TETA-2_AlLEFFs_PV_10-25-02A.IDF & + SMALL PV MODULE \\
\hline PRODUCTION & & (SLIGHT DAYLIGHTING) \\
\hline
\end{tabular}

* A minor bug was introduced in EnergyPlus Version 1.0.3 that causes minimum outdoor air rates to not use the schedules defined in the input object for the Outdoor Air Controller. This had to be corrected in a unique build of EnergyPlus to run the demand-ventilation models with an outside air mixer. Therefore these models do not work properly with the official release Version 1.0.3 of EnergyPlus. Demandventilation schemes functioned in Version 1.0.2 and should work in future EnergyPlus releases. The nonofficial version of EnergyPlus.exe with the bug fixed will be made available along with the input files. 


\section{Appendix D. Economic Modeling of EnergyPlus Results}

EnergyPlus, as a building energy calculation engine, does not include economic analysis. Because the cost of energy is at least as important as the quantity used, using EnergyPlus for design analysis requires computing economic indicators from simulation results for energy consumption. We conducted all analysis of results from EnergyPlus using a custom postprocessing application called HPBAnalyzer. HPBAnalyzer was expanded to allow energy costs to be computed. This appendix documents how energy costs are computed from the results of EnergyPlus simulations.

The cost computations currently assume that utility pricing depends only on the hour of the year and not on volume. Fixed monthly charges are neglected. To provide appropriate hourly data for all energyconsuming equipment, appropriate reporting must be requested in EnergyPlus input files.

Because HPBAnalyzer could already read EnergyPlus schedules from input files, we used these schedule objects to formulate input for utility rates. EnergyPlus simply ignores the presence of these schedules because they are not associated with any other input object in the model. Once the EnergyPlus schedules are read into HPBAnalyzer, they are stored in a floating-point array of dimension $24 \times 365 \times$ number of schedules. Thus electric and gas rates are input in convenient units as for any other EnergyPlus schedule. These schedules use a combination of the input objects "Schedule," "Week Schedule," and "Day Schedule" (see EnergyPlus user documentation an InputOutputReference.pdf). For electricity rates, input is in units of cents per kilowatt-hour and should be for the total charge per kilowatt-hour. Electricity pricing based on time of day and year can be easily handled using EnergyPlus schedules. HPBAnalzyer currently expects the schedule for electricity to be named "ElectricityRateSchedule" (exact string, case sensitive). Gas rates are in units of cents per therm and are also totals without volume-based price ratcheting. HPBAnalzyer currently expects the schedule for gas to be named "GasRateSchedule" (exact string, case sensitive).

In using HPBAnalyzer, different zones can be selected for grouping together to collect results for similar zones. This requires using naming conventions for zone names and variables that allow the HPBAnalyzer routines to associate energy consumption variables appropriately. The routines also search through certain variables to organize variables by end-use type. Array mathematics is used to preserve the hourly nature of the data as results are summed for different zones and common end-use types (e.g., all the fans from $\mathrm{ZN} 2, \mathrm{ZN} 3$, and ZN4 are combined into one array of hourly results). The base rates from schedules are then applied to hourly values for energy consumption with the appropriate conversions (e.g., joules to kilowatt-hours, joules to therms, cents to dollar). These hourly cost data are plotted and summed to result in simple annual totals for end-use energy cost.

We obtained the energy prices used for computing costs for the Teterboro Airport building from "rate schedule GSG," published by the local utility, Public Service Electric and Gas Company, in December 2002. The rates for gas and electricity are listed in Table D-1 for both the predesign analysis presented in Section 2.0 and the higher rates used for the design analysis in the remainder of the report (using EnergyPlus).

Table D-1. Energy Prices

\begin{tabular}{|c|c|c|c|}
\hline Analysis Phase & Fuel & $\begin{array}{c}\text { Daytime } \\
8 \text { A.M. to } 8 \text { P.M. }\end{array}$ & $\begin{array}{c}\text { Nighttime } \\
9 \text { P.M. to } 7 \text { A. M. }\end{array}$ \\
\hline $\begin{array}{l}\text { PREDESIGN } \\
\text { (DOE-2.1E) }\end{array}$ & $\begin{array}{l}\text { ELECTRICITY, WINTER } \\
(\phi / \mathrm{KWH})\end{array}$ & 16.595 & 15.465 \\
\hline
\end{tabular}




\begin{tabular}{llll} 
SPRING 2001 & $\begin{array}{l}\text { ELECTRICITY, SUMMER } \\
(\phi / K W H)\end{array}$ & 17.725 & 16.595 \\
& GAS $(\phi /$ THERM $)$ & 65.84 & 65.84 \\
\hline $\begin{array}{l}\text { DESIGN DEVELOPMENT } \\
\text { (ENERGYPLUS) }\end{array}$ & $\begin{array}{l}\text { ELECTRICITY, WINTER } \\
(\phi / \text { KWH })\end{array}$ & 16.665 & 15.535 \\
DECEMBER 2002 & $\begin{array}{l}\text { ELECTRICITY, SUMMER } \\
(\phi / \text { KWH })\end{array}$ & 17.795 & 16.665 \\
& \begin{tabular}{l} 
GAS $(\phi /$ THERM $)$ \\
\hline
\end{tabular} & 90.1295 & 90.1295 \\
\hline
\end{tabular}




\section{Appendix E. DX Coil Performance Curves}

This appendix documents how DX coil performance curves were generated for use with EnergyPlus from manufacturer's published data tables. Although a modeler could assume that accuracy will not suffer significantly if performance curves from some other DX system are used, the fact that EnergyPlus allows/requires inputting performance curves that are specific to the DX coil being modeled warrants using accurate curves for research-level analysis. The performance curves allow determining capacities and efficiencies of DX cooling coils when they are not operating at the conditions specified for rating. An example is very useful for this discussion, so a specific model of a rooftop package system was selected and its performance data are reproduced in Table E-1 (Carrier 2002).

Table E-1. Example DX Coil Performance Data Table

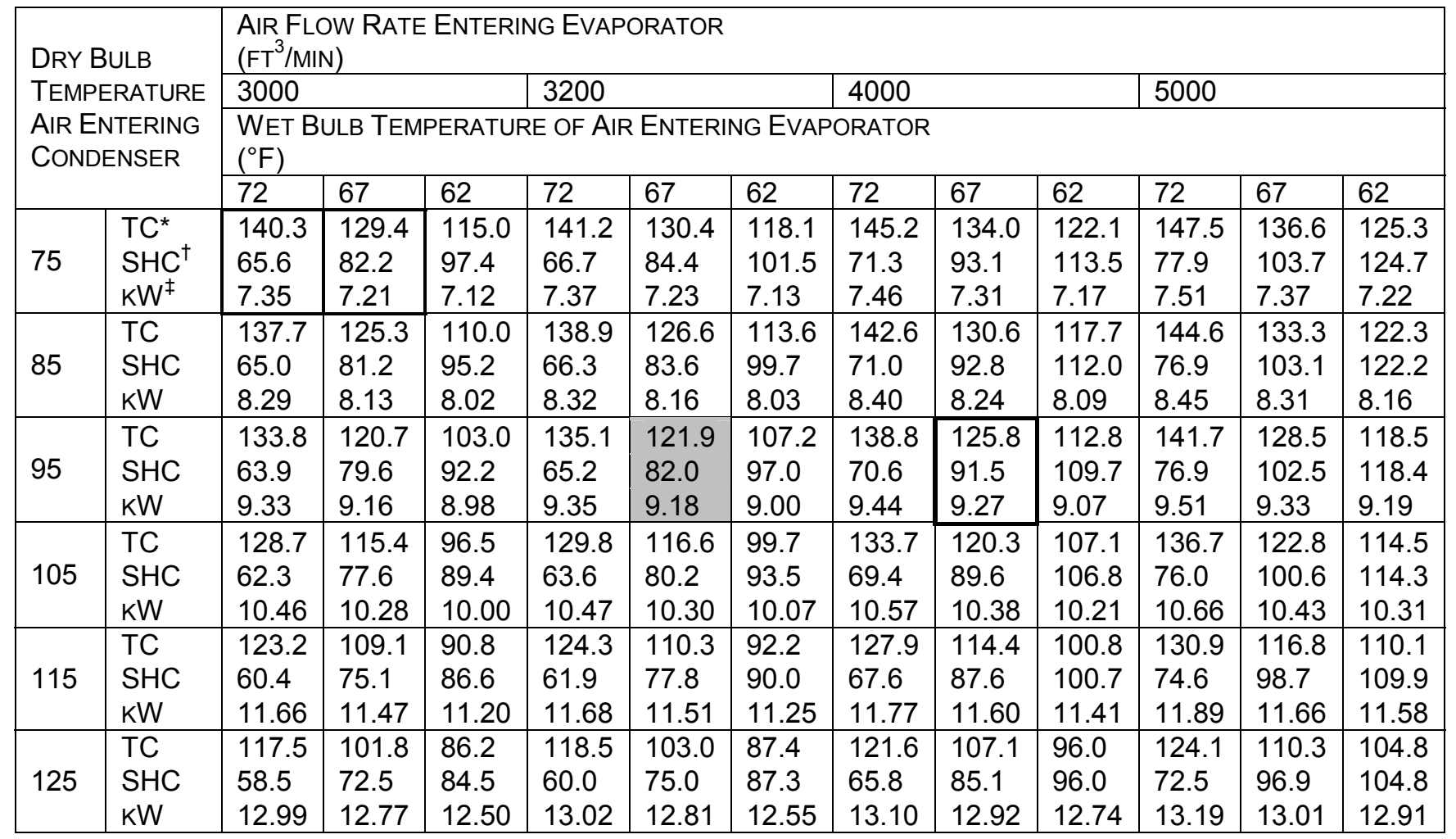

*TC: total or gross cooling capacity in $1000 \mathrm{~s}$ of Btu/hr.

'SHC: sensible cooling capacity in 1000 s of Btu/hr.

${ }^{\dagger} \mathrm{kW}$ : electrical power drawn by coil.

The first step in processing performance data is to convert to EnergyPlus units. Cooling capacities need to be in watts $(\mathrm{W})$, airflow rates need to be in cubic meters per second $\left(\mathrm{m}^{3} / \mathrm{s}\right)$, and temperatures need to be in degrees Centigrade $\left({ }^{\circ} \mathrm{C}\right)$.

The performance levels at a "rating point" are used to normalize the resulting performance curves. The rating point should have an outdoor dry bulb of $35^{\circ} \mathrm{C}\left(95^{\circ} \mathrm{F}\right)$ and air entering the evaporator with a wet bulb of $19.4^{\circ} \mathrm{C}\left(67^{\circ} \mathrm{F}\right)$ and a dry bulb of $26.7^{\circ} \mathrm{C}\left(80^{\circ} \mathrm{F}\right)$. However, the user may need to select an appropriate flow rate for the rating point. In Table E-1, the table entries highlighted with a gray background identify the rating point selected by the manufacturer. However, this rating point does not 
satisfy the ranges accepted by EnergyPlus. EnergyPlus screens input by dividing rated volume flow rate by rated gross capacity, and if they do not fall in a specific range, the DX coil model reports an error and will not work. To check, divide the value for TC (converted to [W]), by the airflow rate (converted to $\left[\mathrm{m}^{3} / \mathrm{s}\right]$ ) and check that values lie between $4.7 \times 10^{-5}$ and $6.04 \times 10^{-5}$. For this example, the rating point selected for EnergyPlus modeling should be for the higher flow rate identified by the heavier outlined box in Table E-1.

Two biquadratic performance curves need to be generated, one for capacity and another for efficiency. The capacity function, $f_{\text {cap }}(x, y)$, is a function of the air wet bulb entering the evaporator coil, $x$, and the air dry bulb entering the condenser, $y$. The capacity function is modeled using a biquadratic equation of the form,

$$
f_{\text {cap }}(x, y)=C_{0}+C_{1} x+C_{2} x^{2}+C_{3} y+C_{4} x y+C_{5} y^{2}
$$

A function fitting routine is then used to find the coefficients in Equation E-1 by processing data sets/points of the form,

$$
\left\{x_{i}, y_{i}, f_{\text {cap }}\left(x_{i}, y_{i}\right)\right\}
$$

where

$x_{i}$ is the evaporator inlet temperature $(16.5,19.3,22.1)$ in degrees Centigrade,

$y_{i}$ is the condenser inlet temperature $(23.8,29.3,34.9,40.4,46.0,51.6)$ in degrees Celsius, and $f_{c a p, i}$ is the normalized value for cooling capacity (at the rated airflow) that are obtained by dividing values for total cooling capacity (TC) from Table E-1 by the value for TC at the rating point.

Figure E-1 shows a plot of a capacity biquadratic curve for the data in Table E-1.

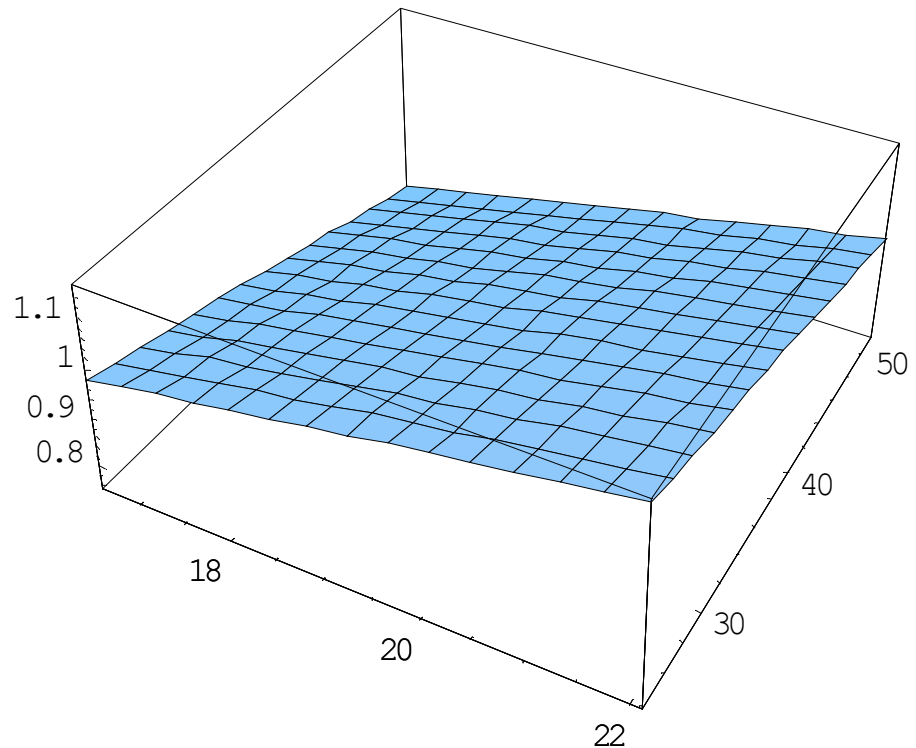

Figure E-1. Plot of example of biquadratic curve for capacity as a function of temperatures 
Similarly, a biquadratic function for the EIR is obtained by fitting data sets of the form shown in Equation E-3 to a function of the form shown in Equation E-1,

$$
\left\{x_{i}, y_{i}, f_{E I R}\left(x_{i}, y_{i}\right)\right\}
$$

where

$x_{i}$ is the evaporator inlet temperature $(16.5,19.3,22.1)$ in degrees Celsius,

$y_{i}$ is the condenser inlet temperature $(23.8,29.3,34.9,40.4,46.0,51.6)$ in degrees Celsius, and $f_{E I R, i}$ is normalized value(s) for EIR (at the rated airflow) that are obtained by dividing values for EIR, computed from data in Table E-1, by the value for EIR at the rating point. EIR is computed using Equation E-4:

$$
\operatorname{EIR}_{i}=\frac{(\text { Compressor power }(W))_{i}}{(\text { Total Cooling Capacity }(W))_{i}}
$$

Figure E-2 is a plot of an energy input ratio biquadratic curve for the data in Table E-1.

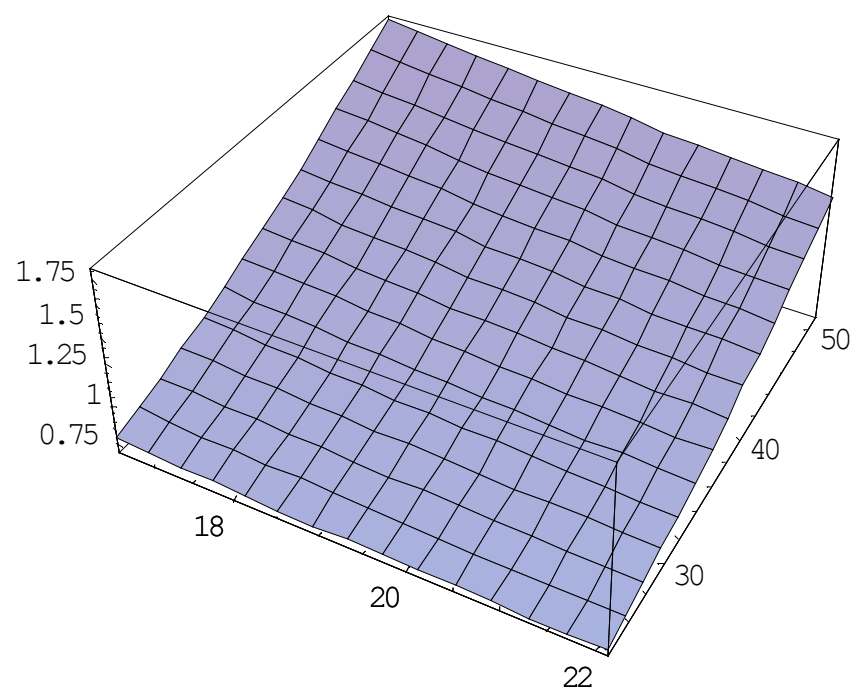

Figure E-2. Plot of example of biquadratic curve for energy input ratio as a function of temperatures

Capacity as a function of airflow through the coil, $f_{c a p}\left(\dot{V}_{i}\right)$, is obtained by fitting data sets of the form,

$$
\left\{\dot{V}_{i} \quad f_{\text {cap }}\left(\dot{V}_{i}\right)\right\}
$$

to quadratic equations of the form,

$$
f_{\text {cap }}\left(\dot{V}_{i}\right)=C_{o}+C_{1} \dot{V}_{i}+C_{2} \dot{V}_{i}^{2}
$$

where

$\dot{V}_{i}$ is volume flow rate of air across the coil. 
The data sets are obtained for constant temperatures selected to match the rating point. Figure E-3 shows a plot of normalized capacity as a function of flow rate for the data in Table E-1.

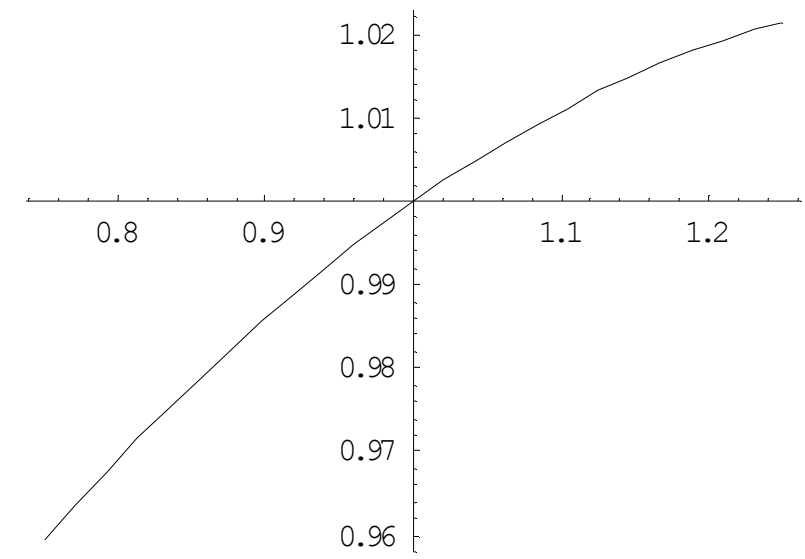

Figure E-3. Plot of an example quadratic performance curve for capacity as a function of flow rate

Efficiency as a function of airflow through the coil, $f_{E I R}\left(\dot{V}_{i}\right)$, is obtained by fitting data sets of the form,

$$
\left\{\dot{V}_{i} \quad f_{E I R}\left(\dot{V}_{i}\right)\right\}
$$

Eq. E-7

to quadratic equations of the form,

$$
f_{E I R}\left(\dot{V}_{i}\right)=C_{o}+C_{1} \dot{V}_{i}+C_{2} \dot{V}_{i}^{2}
$$

Eq. E-8

Figure E-4 is a plot of normalized efficiency as a function of flow rate for the data in Table E-1.

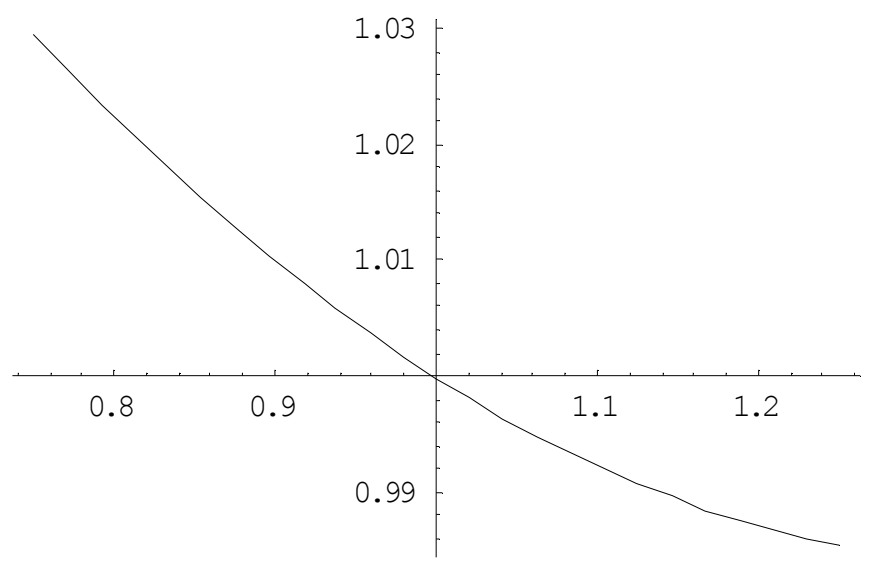

Figure E-4. Plot of an example quadratic performance curve for energy input ratio as a function of flow rate

All four performance curves shown above were generated for each of a total of 11 different packaged DX cooling systems as part of this research effort. 
The part load factor (PLF) is a function of part load ratio (PLR). The relationship used for all the DX models in this report is given in Equation E-9 and is taken from Neymark and Judkoff (2002).

$$
P L F=0.771+0.229 *(\mathrm{PLR})
$$

Eq. E-9 


\section{Appendix F. Comparison of DOE-2.1E and EnergyPlus}

Early in the development of EnergyPlus models for this report, a series of models were completed that more closely matched models done using DOE-2.1E. We include these results to show how EnergyPlus results compare to DOE-2.1E results. The base building is modeled as for ASHRAE 90.1-2001 (e), but differs from the models used in the rest of this report in that schedules, set points, and controls were changed in later models. In this appendix (Figures F-1 and F-2; Tables F-1 and F-2), results are for the entire building rather than for separate garage and office zones.

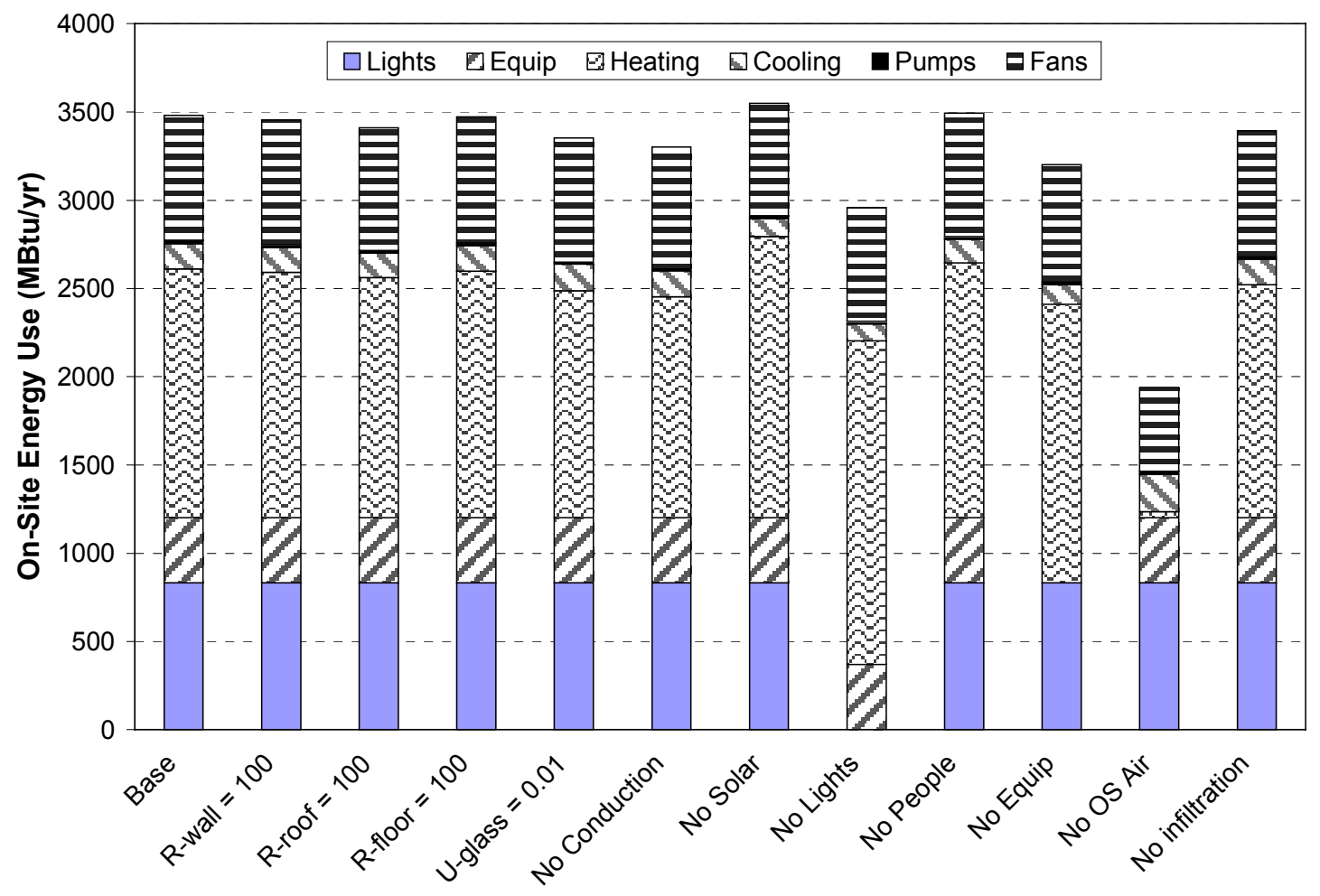

Figure F-1. DOE-2 results for parametric elimination study of proposed Teterboro Airport Building 


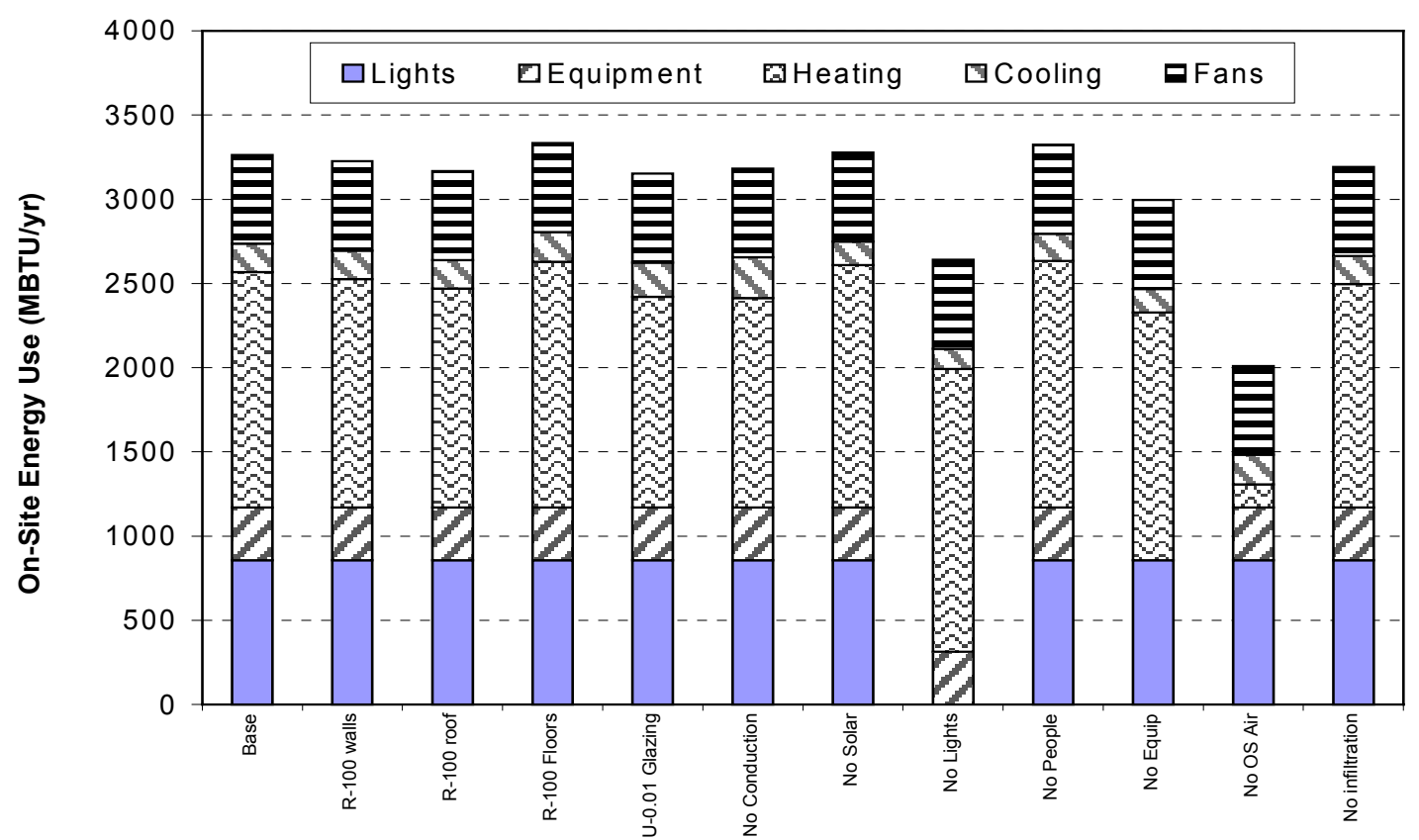

Figure F-2. EnergyPlus results for parametric elimination study of proposed Teterboro Airport Building

Table F-1. DOE-2.1E Whole Building Elimination Results Summary

\begin{tabular}{|c|c|c|c|c|c|c|c|c|c|}
\hline Case & Lights & Equip & $\begin{array}{c}\text { Annual } \\
\text { Heating }\end{array}$ & $\begin{array}{l}\text { Energy Use } \\
\text { Cooling }\end{array}$ & $\begin{array}{l}\text { (MBtu) } \\
\text { Pumps } \\
\end{array}$ & Fans & Total & $\begin{array}{c}\text { EUI } \\
\text { (kBtu/ft2) }\end{array}$ & $\begin{array}{l}\% \text { Change } \\
\text { from Base }\end{array}$ \\
\hline$\overline{\text { Base }}$ & 832.9 & 368.4 & $\bar{~} 1409.8$ & 142.8 & $\overline{c 14.3}$ & $7 \overline{712.5}$ & $\begin{array}{l}3480.7 \\
\end{array}$ & 92.9 & \\
\hline R-wall $=100$ & 832.9 & 368.4 & 1390.2 & 141.5 & 13.8 & 708.0 & 3454.8 & 92.3 & $-0.7 \%$ \\
\hline R-roof $=100$ & 832.9 & 368.4 & 1361.1 & 138.8 & 13.5 & 696.4 & 3411.1 & 91.1 & $-2.0 \%$ \\
\hline R-floor $=100$ & 832.9 & 368.4 & 1397.1 & 145.1 & 14.1 & 714.9 & 3472.5 & 92.7 & $-0.2 \%$ \\
\hline U-glass $=0.01$ & 832.9 & 368.4 & 1286.9 & 149.4 & 11.4 & 704.3 & 3353.3 & 89.5 & $-3.7 \%$ \\
\hline No Conduction & 832.9 & 368.4 & 1250.6 & 147.5 & 11.0 & 690.3 & 3300.7 & 88.1 & $-5.2 \%$ \\
\hline No Solar & 832.9 & 368.4 & 1593.2 & 101.1 & 13.4 & 639.6 & 3548.6 & 94.8 & $2.0 \%$ \\
\hline No Lights & 0.0 & 368.4 & 1833.8 & 96.8 & 14.4 & 645.0 & 2958.4 & 79.0 & $-15.0 \%$ \\
\hline No People & 832.9 & 368.4 & 1444.7 & 132.9 & 14.0 & 701.5 & 3494.4 & 93.3 & $0.4 \%$ \\
\hline No Equip & 832.9 & 0.0 & 1576.4 & 111.5 & 14.2 & 666.5 & 3201.5 & 85.5 & $-8.0 \%$ \\
\hline No OS Air & 832.9 & 368.4 & 33.2 & 212.3 & 16.7 & 475.2 & 1938.7 & 51.8 & $-44.3 \%$ \\
\hline No infiltration & 832.9 & 368.4 & 1320.1 & 144.4 & 13.4 & 714.0 & 3393.2 & 90.6 & $-2.5 \%$ \\
\hline Heat Recovery & 832.9 & 368.4 & 536.3 & 142.8 & 14.3 & 712.6 & 2607.3 & 69.6 & $-25.1 \%$ \\
\hline
\end{tabular}


Table F-2. EnergyPlus Whole Building Elimination Results Summary

\begin{tabular}{|c|c|c|c|c|c|c|c|c|c|}
\hline Case & Lights & Equip & $\begin{array}{l}\text { Annual Ene } \\
\text { Heating }\end{array}$ & $\begin{array}{l}\text { rgy Use (N } \\
\text { Cooling }\end{array}$ & $\begin{array}{l}\text { Btu) } \\
\text { Pumps }\end{array}$ & Fans & Total & $\begin{array}{c}\text { EUI } \\
\text { (kBtu/ft2) }\end{array}$ & $\begin{array}{l}\% \text { Change } \\
\text { from Base }\end{array}$ \\
\hline$\overline{\overline{\text { Base }}}$ & 856.7 & 313.1 & 1398.1 & 10169.1 & $\overline{0.0}$ & 528.5 & 3265.5 & 87.8 & \\
\hline R-wall $=100$ & 856.7 & 313.1 & 1357.1 & 170.8 & 0.0 & 528.5 & 3226.2 & 86.7 & $-1.2 \%$ \\
\hline R-roof $=100$ & 856.7 & 313.1 & 1299.8 & 170.0 & 0.0 & 528.5 & 3168.1 & 85.2 & $-3.0 \%$ \\
\hline R-floor $=100$ & 856.7 & 313.1 & 1460.3 & 176.3 & 0.0 & 528.5 & 3334.8 & 89.7 & $2.1 \%$ \\
\hline U-glass $=0.0$ & 856.7 & 313.1 & 1251.9 & 204.1 & 0.0 & 528.5 & 3154.3 & 84.8 & $-3.4 \%$ \\
\hline No Conductio & 856.7 & 313.1 & 1244.9 & 240.3 & 0.0 & 528.5 & 3183.5 & 85.6 & $-2.5 \%$ \\
\hline No Solar & 856.7 & 313.1 & 1440.0 & 140.7 & 0.0 & 528.5 & 3279.0 & 88.1 & $0.4 \%$ \\
\hline No Lights & 0.0 & 313.1 & 1679.8 & 121.6 & 0.0 & 528.5 & 2643.0 & 71.1 & $-19.1 \%$ \\
\hline No People & 856.7 & 313.1 & 1464.9 & 162.5 & 0.0 & 528.5 & 3325.7 & 89.4 & $1.8 \%$ \\
\hline No Equip & 856.7 & 0.0 & 1472.6 & 138.8 & 0.0 & 528.5 & 2996.6 & 80.6 & $-8.2 \%$ \\
\hline No OS Air & 856.7 & 313.1 & 138.5 & 175.4 & 0.0 & 528.5 & 2012.2 & 54.1 & $-38.4 \%$ \\
\hline No infiltration & 856.7 & 313.1 & 1328.8 & 165.2 & 0.0 & 528.5 & 3192.3 & 85.8 & $-2.2 \%$ \\
\hline
\end{tabular}

Notes: The DOE-2.1E HVAC system is a chiller/boiler VAV system; the EnergyPlus model is a constantvolume DX rooftop package system.

Zoning differences lead to slight differences in internal loads for lights, equipment, and people. 


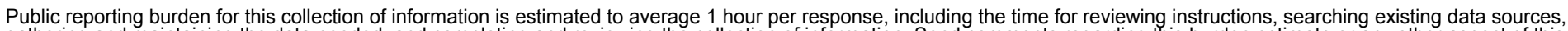

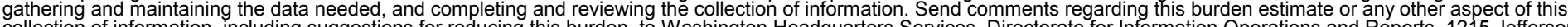

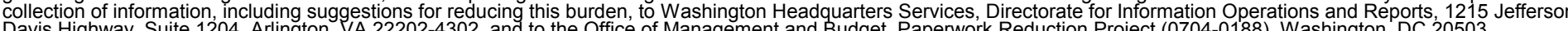

Davis Highway, Suite 1204, Arlington, VA 22202-4302, and to the Office of Management and Budget, Paperwork Reduction Project (0704-0188), Washington, DC 20503.
1. AGENCY USE ONLY (Leave blank)
2. REPORT DATE
July 2003
3. REPORT TYPE AND DATES COVERED
Technical report

4. TITLE AND SUBTITLE

Energy Design Analysis and Evaluation of a Proposed Air Rescue and Fire Fighting Administration Building for Teterboro Airport

5. FUNDING NUMBERS

BEC3.4005

6. $\operatorname{AUTHOR}(\mathrm{S})$

B.Griffith; S. Pless; B. Talbert; M. Deru; P. Torcellini

7. PERFORMING ORGANIZATION NAME(S) AND ADDRESS(ES)

National Renewable Energy Laboratory

1617 Cole Blvd.

8. PERFORMING ORGANIZATION

REPORT NUMBER

Golden, CO 80401-3393

9. SPONSORING/MONITORING AGENCY NAME(S) AND ADDRESS(ES)

10. SPONSORING/MONITORING AGENCY REPORT NUMBER

\section{SUPPLEMENTARY NOTES}

12a. DISTRIBUTION/AVAILABILITY STATEMENT

National Technical Information Service

12b. DISTRIBUTION CODE

U.S. Department of Commerce

5285 Port Royal Road

Springfield, VA 22161

1. 13. ABSTRACT (Maximum 200 words) A new/proposed building for the Teterboro Airport was selected as a case study for High Performance Building Initiative research efforts. This report documents research-level energy analysis conducted on the Teterboro Airport building during predesign and design phases of the project.

2. 14. SubJeCt terms High Performance Buildings; Teterboro Airport; New Jersey;

15. NUMBER OF PAGES energy design analysis; building design analysis.

16. PRICE CODE

17. SECURITY CLASSIFICATION OF REPORT Unclassified
18. SECURITY CLASSIFICATION OF THIS PAGE Unclassified
19. SECURITY CLASSIFICATION OF ABSTRACT Unclassified
20. LIMITATION OF ABSTRACT

UL 